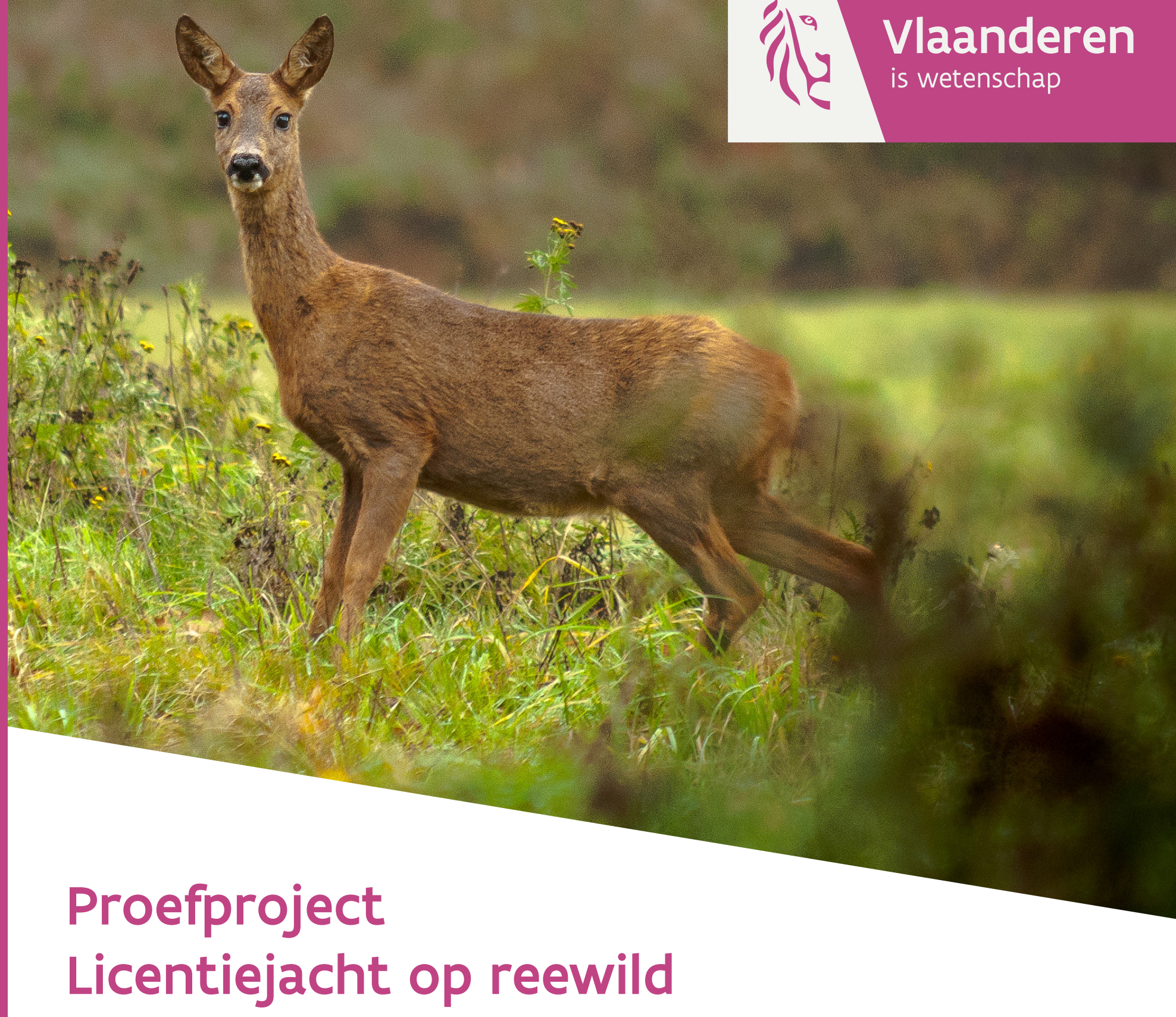

Basisrapport van het proefproject rond de licentiejacht in het Gewestbos Ravels en Hoge Vijvers Arendonk

Jim Casaer, Anneleen Rutten, Jan Vercammen, Sander Devisscher, Beatrijs Van der Aa, Axel Neukermans, Peter Van de Kerckhove, Kris Vandekerkhove en Frank Huysentruyt

INSTITUUT

NATUUR- EN BOSONDERZOEK 


\section{Auteurs:}

Jim Casaer, Anneleen Rutten, Jan Vercammen, Sander Devisscher, Beatrijs Van der Aa, Axel Neukermans, Peter Van de Kerckhove, Kris Vandekerkhove en Frank Huysentruyt Instituut voor Natuur- en Bosonderzoek

\section{Reviewers:}

Niko Boone

Het INBO is het onafhankelijk onderzoeksinstituut van de Vlaamse overheid dat via toegepast wetenschappelijk onderzoek, data- en kennisontsluiting het biodiversiteitsbeleid en -beheer onderbouwt en evalueert.

\section{Vestiging:}

INBO VAC Brussel

Havenlaan 88, 1000 Brussel

www.inbo.be

\section{e-mail:}

jim.casaer@inbo.be

\section{Wijze van citeren:}

J. Casaer, A. Rutten, J. Vercammen, S. Devisscher, B. Van der Aa, A. Neukermans, P. Van de Kerckhove, K. Vandekerkhove en F. Huysentruyt. Proefproject Licentiejacht op reewild: Basisrapport van het proefproject rond de licentiejacht in het Gewestbos Ravels en Hoge Vijvers Arendonk. Rapporten van het Instituut voor Natuur- en Bosonderzoek 2020 (45). Instituut voor Natuur- en Bosonderzoek, Brussel.

DOI: doi.org/10.21436/inbor.19108481

\section{D/2020/3241/298}

Rapporten van het Instituut voor Natuur- en Bosonderzoek 2020 (45)

ISSN: 1782-9054

Verantwoordelijke uitgever:

Maurice Hoffmann

Foto cover:

(C) Van Bladel Rudi 
INSTITUUT

NATUUR- EN

BOSONDERZOEK

\title{
PROEFPROJECT LICENTIEJACHT OP REEWILD
}

\author{
Basisrapport van het proefproject rond de \\ licentiejacht in het Gewestbos Ravels en Hoge \\ Vijvers Arendonk
}

Jim Casaer, Anneleen Rutten, Jan Vercammen, Sander Devisscher, Beatrijs Van der Aa, Axel Neukermans, Peter Van de Kerckhove, Kris Vandekerkhove en Frank Huysentruyt

doi.org/10.21436/inbor.19108481 


\section{Dankwoord}

Dit project was nooit mogelijk geweest zonder de intense en constructieve samenwerking tussen een aantal mensen en organisaties en het vertrouwen dat we als projectuitvoerders kregen van alle betrokken partijen.

In eerste instantie dank aan de directies van zowel het ANB als het INBO die groen licht gaven om dit project gedurende tien jaren te laten lopen. Dit soort projecten vergt dan wel maar een eerder beperkte jaarlijkse inspanning, maar deze moet lang vol gehouden kunnen worden. Het bestuderen en evalueren van ecologische processen en het beheer van wildsoorten vraagt immers om herhalingen over seizoenen en jaren heen.

Dank ook aan de leden van de stuurgroep die doorheen het project jaarlijks feedback gaven en ook het eindrapport doornamen en becommentarieerden. De inbreng en uitwisseling van kennis, ervaringen en meningen met de leden van de stuurgroep heeft zeker bijgedragen aan het welslagen van het project en het tot stand komen van dit uiteindelijke rapport.

We willen uiteraard ook de licentiehouders zelf bedanken. Zij leverden telkens de nodige inspanningen om stalen te verzamelen, de jachtdagboekjes in te vullen, naast de praktische inspanningen die ze ook op het terrein uitvoerden om de jachtactiviteiten jaarlijks goed te laten verlopen. Dank ook aan het personeel van ANB, dat, samen met enkele lokale jagers en vrijwilligers, de ondersteuning op het terrein leverde door permanentie uit te voeren, licentiehouders bij te staan, gekwetst wild na te zoeken of deel te nemen aan de jaarlijkse reetellingen.

En tenslotte dank aan alle INBO-medewerkers en stagiairs, uit verschillende teams, die doorheen het project een bijdrage leverden op het terrein, in het labo, bij de verwerking van de data of bij het tot stand komen van dit rapport. 


\section{Samenvatting}

Dit rapport behandelt verschillende dimensies van het proefproject rond de licentiejacht in de overheidsbossen van Ravels en Arendonk in de periode 2010 - 2019. Bij de verpachting onder vorm van licenties verwierven de licentiehouders de toelating tot jagen onder bepaalde voorwaarden voor een korte periode (vastgelegd aantal dagen in winter of zomer).

Het systeem liet de terreinbeheerder per deelgebied toe jaarlijks bij te sturen in functie van het verwezenlijken van de vooropgestelde doelen. Zo konden bijvoorbeeld het aantal licenties, de jachtperiodes zowel als het aantal gemeenschappelijke aanzitmomenten worden gewijzigd. Deze werkwijze resulteerde in een afschotrealisatie die doorheen het project hoger lag dan gemiddeld in Vlaanderen.

Tijdens het project noteerden de licentiehouders de gegevens van elke aanzit in een jachtdagboekje. Ook werden de reepopulaties in beide deelgebieden opgevolgd aan de hand van gestandaardiseerde kilometertellingen. De tellingen toonden aan dat de hoge afschotrealisatie resulteerde in de vooropgestelde daling van de reewildstand in beide deelgebieden. Uit de analyse van de jachtdagboekjes blijkt dat gelijklopend hieraan het aantal waargenomen reeën per aangezeten uur daalde en dat de tijd tot de eerste reewaarneming gedurende een aanzit toenam. Wel bleef het aandeel aanzitten met waarnemingen van reeën zo goed als gelijk doorheen het project.

Gedurende het project stelden we een stijging van de onderkaaklengtes en van de leeggewichten van de kitsen vast. Beide parameters zijn voor reewild gevalideerde bioindicatoren die een beeld geven van de verhouding tussen de draagkracht van het gebied en de aanwezige reewildstand. Het lag dan ook binnen de verwachtingen dat deze indicatoren zouden stijgen bij een populatiedaling. Zeker omdat beide waarden, in vergelijking met andere gebieden in Vlaanderen uit dezelfde periode, relatief laag waren bij de start van het project.

Het beoogde effect wat betreft de daling van de druk door reeën op de bosverjonging, kon slechts gedeeltelijk geëvalueerd worden, doordat de eerste terreinopnamen hiervoor pas in 2016 plaatsvonden. Op dat moment was het project al zes jaar bezig en was de populatie in beide deelgebieden al gedaald. Tussen 2016 en 2019 werd een lichte maar niet significante daling in de algemene druk van ree op houtige plantensoorten waargenomen. De druk op de loofboomsoorten en struikgewas was hoger dan op de naaldboomsoorten. Een aandachtspunt voor verder onderzoek was het groot aantal opnameplots in het bos waar geen houtige plantensoorten aanwezig waren.

Doordat buiten het proefgebied een aantal jagers vrijwillig gebruik maakten van jachtdagboekjes, konden de jachtefficiëntie (afschot per aangezeten uur) en de selectiviteit (\% van de waarnemingen waarbij ook geschoten werd) vergeleken worden binnen en buiten het proefgebied. De interpretatie van deze resultaten vraagt de nodige voorzichtigheid omdat het aantal jagers die buiten het proefproject jachtdagboekjes bijhielden beperkt was en erg fluctueerde. De data van buiten het proefgebied kunnen dus niet als een representatieve steekproef voor Vlaanderen beschouwd worden. Uit deze vergelijking blijkt dat de licentiehouders vaker ( 1 afschot op 3 waarnemingen) tot afschot kwamen dan de jagers buiten het proefgebied (1 op 5) (significant verschil). De jachtefficiëntie was iets hoger voor de licentiehouders, maar dit verschil is niet significant.

De verpachting onder vorm van licenties liet toe om in een zeer beperkte en geconcentreerde periode, een hoger dan gemiddeld afschot te realiseren en een daling van de voorjaarsstand tot stand te brengen. 
Voor een diepgaande economische vergelijking tussen de verpachting onder vorm van licenties en klassieke verpachtingen, zijn te weinig gegevens beschikbaar. Vast staat wel dat aan het verpachten van de jacht via licenties inherent kosten verbonden zijn voor de overheid/terreinbeheerder voor wat betreft infrastructuur (bv. hoogzitten) en de inzet van personeel.

Licenties worden toegekend aan de hoogste bieders. Wel werd geconstateerd dat de prijs per licentie vanaf 2016 toeneemt, wat, al dan niet toevallig, samenvalt met de opkomst van everzwijnen en de daarbij horende mogelijkheid om als licentiehouder deel te nemen aan everzwijndrukjachten georganiseerd door ANB. De inkomst per 100 ha uit de licentiejacht was van dezelfde grootteorde als van andere verpachtingen door het ANB.

De resultaten van een bevraging van licentiehouders zijn in het algemeen positief tot heel positief. De meeste licentiehouders zouden in de toekomst terug deelnemen, zien het als een systeem dat ook in andere overheidsgebieden toegepast kan worden en zouden andere jagers ook aanraden er aan deel te nemen. De meningen tussen de licentiehouders waren het meest verdeeld over de mate waarin het systeem nadelig is voor de omliggende WBE's en jachtrechthouders, de selectiviteit van het afschot en over de uitspraak dat het systeem vooral geschikt is voor ree en minder voor everzwijn.

Uit gesprekken met vertegenwoordigers van de jachtsector blijkt dat, eerder dan met het systeem van verpachtingen via licenties op zich, er een aantal heel concrete, maar technisch relatief eenvoudig te overkomen problemen ervaren worden met de toepassing ervan in Vlaanderen. Wel blijkt dat er onderliggende gevoeligheden en spanningen zijn tussen de jachtsector en de overheid die de nodige aandacht vergen om een constructieve samenwerking rond het wildbeheer in de toekomst te verzekeren. Hierbij nemen de afstemming rond beheerdoelstellingen, het betrekken van omliggende jachtterreinen bij jachtterreinoverschrijdend wildbeheer, wederzijds respect en een transparante communicatie een centrale plaats in voor de jachtsector.

\section{Enkele methodologische aspecten}

Het proefproject liet het INBO toe een aantal instrumenten in het kader van het adaptief grofwildbeheer in Vlaanderen verder op punt te stellen.

De kilometertellingen te voet in combinatie met het opvolgen van de onderkaaklengte en de leeggewichten van de kitsen toonden in dit project opnieuw hun meerwaarde als eenvoudig toepasbare instrumenten voor een transparant, adaptief reewildbeheer. Het ontbreken van reevraatmetingen vanaf de start van het project vormde duidelijk een gemis en het operationaliseren van het opvolgen van de druk op de vegetatie samen met de andere bioindicatoren, moet in de toekomst een extra aandachtspunt vormen. Het opnameprotocol en de analysemethoden voor de kleine opnameplots $(1 \mathrm{~m} 2)$ bleken goed te implementeren, maar de methodes voor het opnemen van reevraat binnen en buiten de reewerende rasters moeten verder uitgewerkt worden. Een afstemming met de in Wallonië toegepaste methode lijkt aangewezen.

Het meten van de afstanden bij elke waarneming van reeën tijdens de kilometertellingen bewees zijn meerwaarde. Een algemene toepassing ervan bij het uitvoeren van kilometertellingen lijkt zinvol.

Het gebruik van jachtdagboekjes als instrument om op een gestandaardiseerde wijze jachtdata te verzamelen bewees eveneens zijn meerwaarde om kennis te verwerven over de geleverde inspanningen, jachtefficiëntie en selectiviteit. Daarnaast liet de opgedane ervaring het INBO toe om het gebruik ervan te verfijnen. De controle op de volledigheid en nauwgezetheid bij het

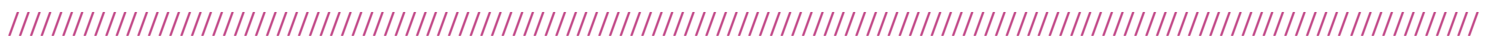


invullen van de jachtdagboekjes is hierbij belangrijk. De deelnemende jagers vonden de jachtdagboekjes gebruiksvriendelijk tot zeer gebruiksvriendelijk. De meerderheid geeft ook aan dat een digitale app (smartphone) voor deze dataverzameling wenselijk is. 


\section{Aanbevelingen voor beheer en/of beleid}

Het proefproject rond licentiejacht op reewild toonde aan dat een systeem van verpachting via licenties de overheid/terreinbeheerder toelaat op een zeer flexibele manier het ree- en everzwijnbeheer in haar terreinen bij te sturen om de beheerdoelstellingen te bereiken en dat dit beheer op een constructieve en positieve manier kan gebeuren met de jagers die deelnemen als licentiehouders.

In dit concrete geval werd de nagestreefde reductie van de reepopulatie verwezenlijkt aan de hand van korte, intensieve jachtperiodes. Daarnaast liet het systeem van de verpachting via licenties ANB ook toe om op een snelle en eenvoudige manier als terreinbeheerder en jachtrechthouder te reageren op de opkomst van het everzwijn in het proefgebied tijdens de projectperiode.

Dit resultaat was enkel mogelijk door de samenwerking en de inbreng van kennis, expertise en ervaring van enkele gemotiveerde lokale jagers, ANB en de wetenschappelijke opvolging door het INBO als basis voor het bijsturen van het beheer. Dit illustreert dat deze vorm van verpachting de nodige tijd, ervaring en kennis bij de overheid vergt om succesvol te zijn.

Door de licentiehouders werd het proefproject als positief tot heel positief ervaren. Bij de jachtsector leven er momenteel vragen over een aantal concrete aspecten van verpachtingen via licenties in Vlaanderen: naast de wettelijke verankering spelen ook de vraag rond expertise bij de lokale beheerders, afstemming met en het betrekken van de omliggende wildbeheereenheden en een transparante communicatie over beheerdoelstellingen en gekozen maatregelen hierbij een grote rol. Zowel gedurende het project, als bij de bespreking van dit rapport en de eindstuurgroep kwam het verschil in mening en visie tussen ANB en de jachtsector voor wat betreft de juridische verankering van licentiejacht in Vlaanderen als een belangrijk knelpunt naar voor. Omdat dit meningsverschil een hindernis vormt voor een inhoudelijke discussie over het al dan niet toepassen van licentiejacht in toekomstige gevallen, is het aan te bevelen de juridische verankering verder uit te klaren en licentiejacht wettelijk te definiëren en omlijnen. Voorbeelden uit het buitenland of Wallonië kunnen hier zeker richtinggevend zijn. Het verschil tussen 'de toelating om onder bepaalde voorwaarden (periode, aantal dieren,..) te mogen jagen op een terrein' en het 'verwerven van het jachtrecht' vormt hierbij een belangrijk punt.

Wanneer met deze bezorgdheden vanuit de jachtsector rekening wordt gehouden en er voldoende ruimte en middelen voor de organisatie van het jachtgebeuren, de monitoring, evaluatie en bijsturing, zowel als voor de communicatie en afstemming met omliggende wildbeheereenheden wordt voorzien, lijkt het systeem van verpachtingen via licenties als bijkomend instrument voor een efficiënt grofwildbeheer in overheidsgebieden een plaats te verdienen in Vlaanderen. Het laat de overheid/terreinbeheerder toe om flexibel in te spelen op steeds veranderende omstandigheden op het terrein en om het multifunctioneel wildbeheer optimaal af te stemmen met de andere functies van deze overheidsgebieden.

In het proefproject werd gewerkt met licenties voor een korte periode (2 weken), in combinatie met de deelname aan eventuele gemeenschappelijke aanzitten en drukjachten op everzwijn. De concrete invullingen van licenties (duur, wildsoorten, jachtmethoden) en het al dan niet combineren van verschillende soorten licenties binnen één overheidsgebied (aanzit/drukjacht/combinatie) zal telkens bepaald moeten worden in functie van faunabeheeren andere doelstellingen voor een specifieke gebied.

Het project toonde tot slot het belang aan van een wetenschappelijk onderbouwde monitoring van zowel de geleverde inspanningen als de afschotrealisaties en de gevolgen ervan als basis

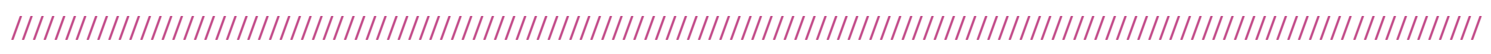


voor een transparante evaluatie en bijsturing van het faunabeheer. Een verdere uitrol hiervan voor het faunabeheer in alle overheidsgebieden, en bij uitbreiding in heel Vlaanderen, is daarom aangewezen. 


\section{Keuze in de praktijk tussen licenties of klassieke verpachting}

Een verpachting aan de hand licenties kan voordelen hebben in die situaties waar een directe en flexibele aansturing van het grofwildbeheer door de terreinbeheerder/eigenaar op het terrein wenselijk is (zie ook bijlage 3). Hierbij denken we aan grote tot middelgrote gebieden op momenten dat er een omvormingsbeheer plaatsvindt, er grote veranderingen in de grofwildbeheerdoelstellingen of maatregelen verwacht worden op korte tot middellange tijd of wanneer men nieuwe methodes wil uittesten (bv. in het kader van wetenschappelijk onderzoek of pilootstudies). Voorbeelden zijn de opkomst van nieuwe soorten (bv. everzwijn, maar ook invasieve soorten zoals wasbeer of muntjak) en het omvormingsbeheer van naaldnaar loofbos door het bevorderen van de natuurlijke verjonging. Het werken met licenties laat de beheerder immers toe jaarlijks zelf te beslissen over de concrete uitvoering van het wildbeheer. Dat kan gaan over het aantal jagers (licenties), de jachtstrategie, de locaties waar gejaagd wordt en de periodes waarbinnen dat mag gebeuren. Ook de mogelijkheid om in de loop van het jaar zelf de jachtinspanningen te kunnen bijsturen in functie van het gewenste/te realiseren afschot is voor de terreinbeheerder een voordeel van de aanpak via licenties. Een langlopende verpachting waarbij de verpachter zich het recht behoudt om ten alle tijden de voorwaarden rond de uitvoering van het beheer bij te sturen vormt op zich zowel voor potentiële pachters (die daardoor weinig zekerheid hebben), als voor de verpachter in dergelijke situaties geen optimaal instrument.

Ook in middelgrote tot grote gebieden waar er nog nooit of reeds langere tijd niet gejaagd werd, biedt een verpachting via licenties de terreinbeheerder het voordeel om ervaring met grofwildbeheer op te doen en het geleidelijk op punt te stellen, zonder direct een langlopende verpachting aan te gaan of van bij het begin al alle bepalingen vast te moeten leggen dan wel de potentiële jachtpachters te laten bieden op een 'blanco check'.

De afstemming als onafhankelijke jager (jachtterrein) met de betrokken WBE('s) vormt een aandachtspunt en vereist een transparante onderlinge communicatie.

De inzet van klassieke verpachting vereist op zich minder inzet van mensen en middelen van de terreineigenaar/beheerder en laat toe maximaal gebruik te maken van de aanwezige expertise, terreinkennis en beschikbare tijd en interesse van (lokale) jagers. In situaties waar de grofwildbeheerdoelstellingen voor de volgende jaren duidelijk zijn en vastliggen, en er geen nood is aan hoge flexibiliteit om gaandeweg het beheer te kunnen bijsturen, biedt een klassieke verpachting voordelen. Het vergt een minder grote inspanning en opvolging van de verpachter en geeft ruimte aan de jagers die de jacht pachten om zelf in hoge mate keuzes te maken en invulling te geven aan het grofwildbeheer. Duidelijke beheerdoelstellingen en modaliteiten voor het uitvoeren van de jacht moeten in de verpachtingsvoorwaarden opgenomen zijn. Onduidelijkheid hierover bij de verpachting brengt het risico op verschillen in interpretatie en verkeerde verwachtingen met zich mee.

Bij een klassieke verpachting kan het jachtterrein deel uitmaken van een WBE. Ook dan kunnen er echter nog steeds verschillen zijn in de beheerdoelstellingen en toegepaste maatregelen in het verpachte terrein ten opzichte van de rest van de WBE. 


\section{English abstract}

This report focuses on the different dimensions of the use of licences as an alternative for leasing the hunting rights of public forests to hunters. The latter is the current legal enforced condition to be able to hunt or manage game populations on public land in Flanders.

The pilot project took place in the public forest of Ravels and Arendonk from 2010 until 2019. The lease of a hunting licence implied that the licence holder obtains the hunting admission under certain conditions for a short period (a number of days in winter or summer). This system allowed the forest administration to adjust yearly the number of licences and number of hunting days in order to reach the set management goals. These adjustments resulted in an annual realisation of the set hunting quota which was generally higher than the average realisation in Flanders.

Roe deer population trends in both areas were assessed using a standardized kilometre index method. These counts showed that the high hunting realisation resulted in a reduced population in both areas, which was one of the roe deer management goals set at the start of the project.

During the project, licence holders filled in hunting logbooks. The analysis of these data showed that the number of observed roe deer per hour hunting effort decreased and that the time until the first roe deer observation increased. The portion of hunts during which roe deer were observed remained the same throughout the project.

An increase of lower jaw length and dressed body weight of roe deer fawns was observed during the project. Both are validated bio indicators for roe deer which reflects the ratio between ecological carrying capacity of an area and the roe deer densities. The observed amelioration of these bio indicators was one of the management goals set.

The possible effect of the decreased pressure of roe deer on forest regeneration could only be partially evaluated because the required measurements in the field only started in 2016, 6 years after the start of the project. Between the first (2016) and second (2019) field survey, a slight but non-significant decrease of roe deer pressure on woody plants was found.

Comparison with hunters outside of the pilot area revealed that licence holders shoot sooner (1 out of 3 times roe deer were observed they shot one) than hunters outside the project area (1 out of 5). Hunting efficacy was slightly higher for licence holders, although this difference was not significant. The use of licences allowed hunting in a shorter period with a higher than average hunting realisation.

A detailed comparison of the economic aspects of a lease using licences with a classical hunting territory lease was not possible due to the lack of required information. The use of licences does however imply extra costs for the terrain owner for hunting infrastructure (for example high seats) and staff. Direct revenues from selling licences, recalculated per 100 ha was comparable with the income generated from other leases by ANB.

A online survey revealed that the licence holders experiences with the project are positive to very positive. Most licence holders would take a new licence in the future, they think the system of licences can also be put to practice in other government areas and they would recommend other hunters to take part in licence hunting systems. Opinions were divided on the fact if licence hunting has disadvantages for neighbouring wildlife management units (WBE) and hunting right holders, the selectivity of shot animals and if the system of licences is mostly suitable for roe deer but not for wild boar. 
From focus groups with representatives of the hunting sector, it became clear that not the system of using licences itself but a number of concrete, but technically relative simple to solve, issues exist regarding using hunting licences in Flanders as an alternative system. The focus groups also revealed some tensions between the hunting sector and forestry administration which should be taken into account to assure constructive cooperation for wildlife management in the future. For the hunting sector, the following aspects are important to guarantee a constructive collaboration: agreeing on or respecting the management goals of all stakeholders involved, closer involvement of surrounding hunting territories during management meetings, mutual respect and transparent communication. 


\section{Inhoudstafel}

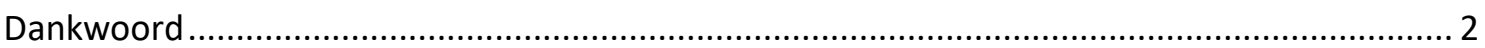

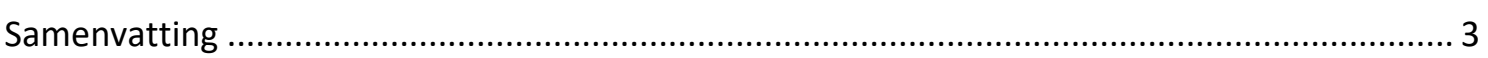

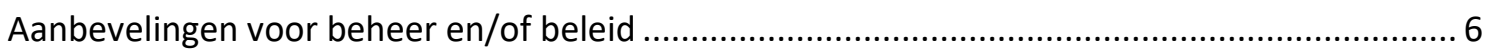

Keuze in de praktijk tussen licenties of klassieke verpachting................................................... 8

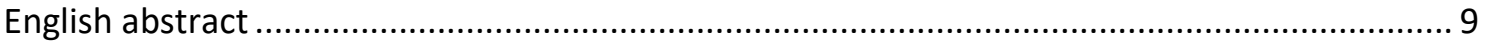

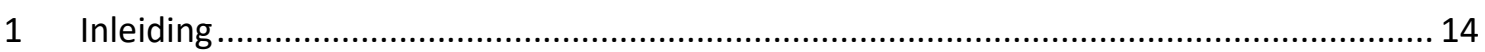

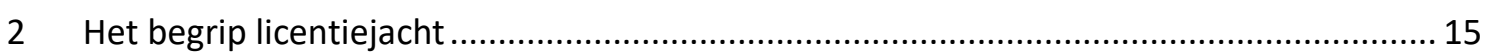

2.1 Mogelijke systemen van jachtverpachting of toekennen van de toelating tot jagen. 15

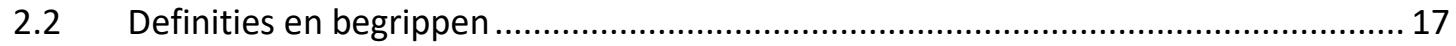

2.3 De keuze voor het gebruik van afschotlicenties in een revierjachtsysteem................ 18

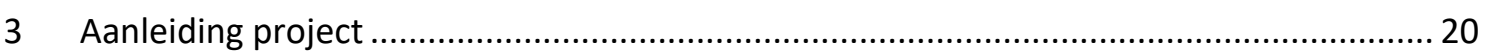

4 Gebieden en concrete toepassing van afschotlicenties in het proefproject ...................... 23

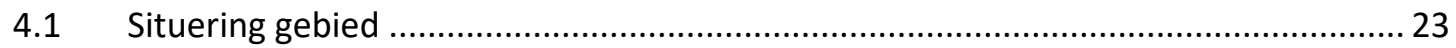

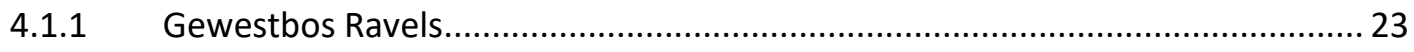

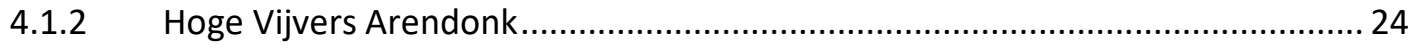

4.2 Historiek van de jacht in beide domeinbossen ......................................................... 25

4.3 Toepassing van afschotlicenties in het proefproject ................................................. 25

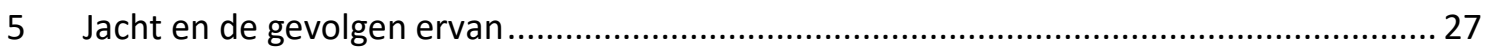

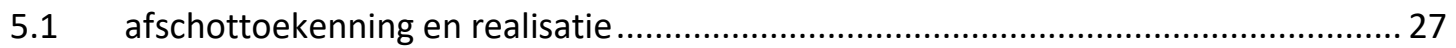

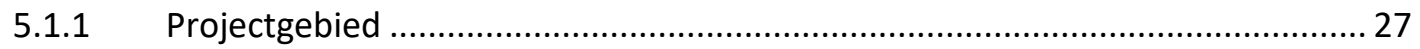

5.1.2 Vergelijking met de rest van Vlaanderen, de provincie Antwerpen en de

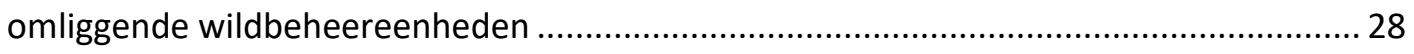

5.1.3 Conclusie van de afschottoekenning en realisatie ............................................. 29

5.2 Jachtinspanningen, efficiëntie en selectiviteit ........................................................ 29

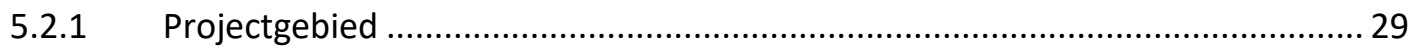

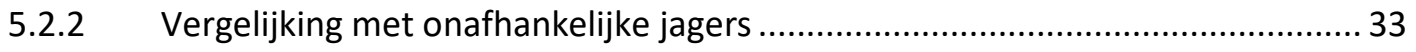

5.2.3 Conclusie van jachtefficiëntie en selectiviteit .................................................... 35

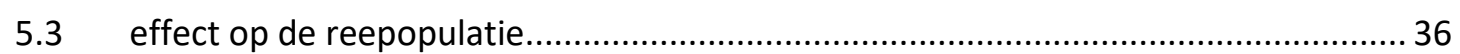

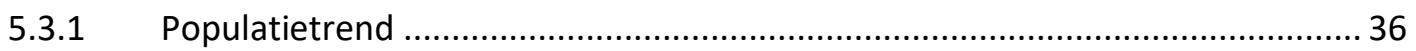

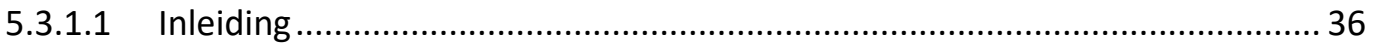

5.3.1.2 Toepassing van de kilometerindex in het kader van het licentiejachtproject 36

5.3.1.3 Resultaten van de kilometertellingen in Ravels en Arendonk ......................... 38

5.3.1.4 Waarnemingen gedurende de aanzit........................................................... 40

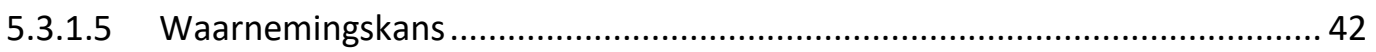

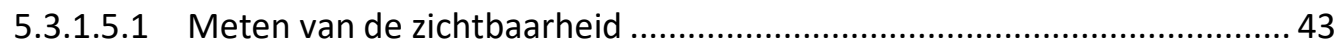

5.3.1.5.2 Meten van de waarnemingsafstand ......................................................... 44 


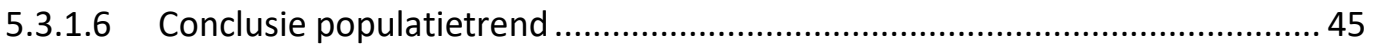

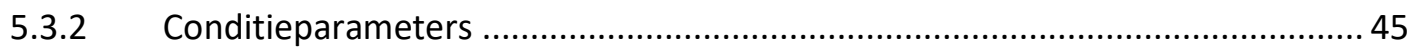

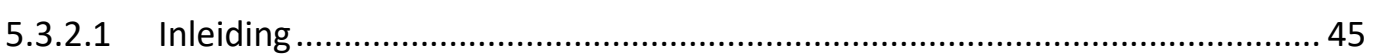

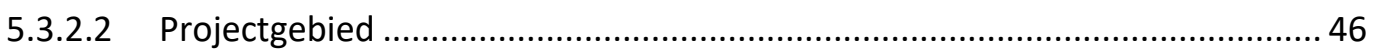

5.3.2.2.1 Leeggewicht en onderkaaklengte van de kitsen ..................................... 46

5.3.2.2.2 Aantal drachtige geiten, aantal embryo's per drachtige geit ................... 47

5.3.2.3 Vergelijking met de rest van Vlaanderen, de provincie Antwerpen en de omliggende wildbeheereenheden .............................................................................. 48

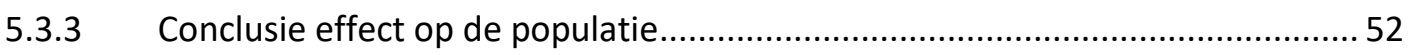

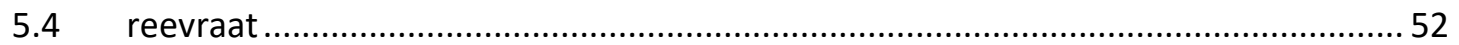

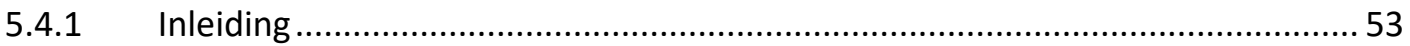

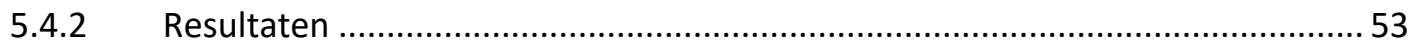

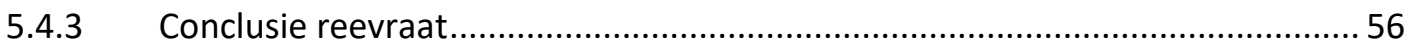

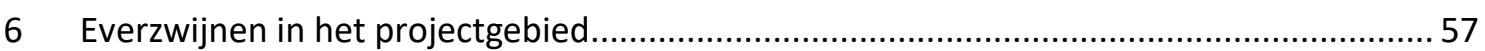

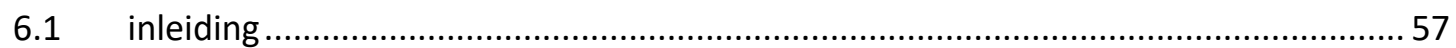

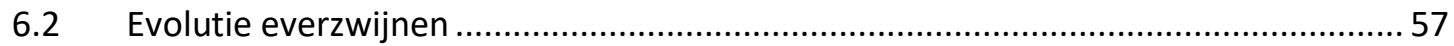

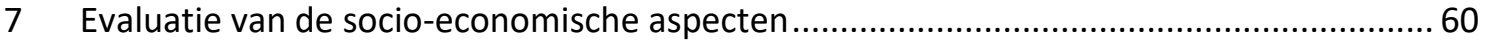

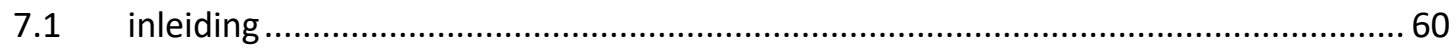

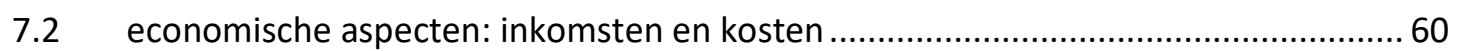

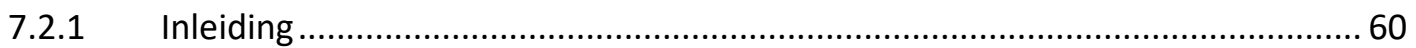

7.2.2 Inkomsten uit licentiejacht voor de verpachtende overheid ..............................61

7.2.3 Kosten van licentiejacht voor de verpachtende overheid ..................................62

7.2.4 Kosten voor de deelnemende jagers aan licentiejacht ....................................... 63

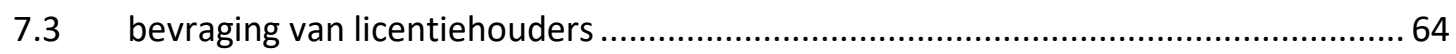

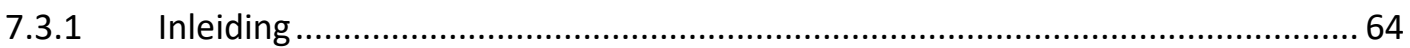

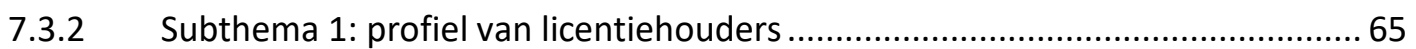

7.3.3 Subthema 2: ervaringen, verwachtingen en meningen ..................................... 67

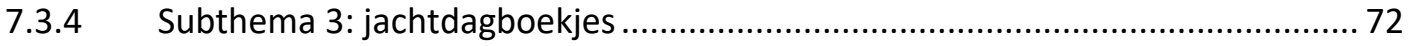

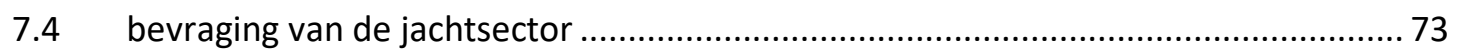

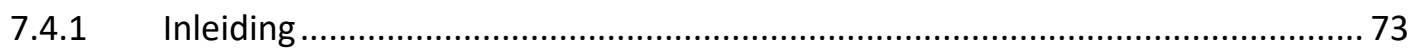

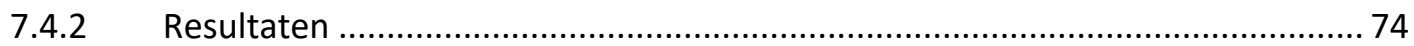

7.4.2.1 Gebruik van afschotlicenties in het algemeen ........................................... 74

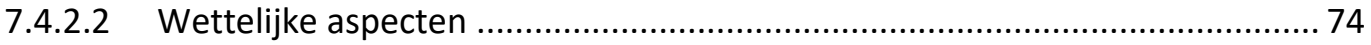

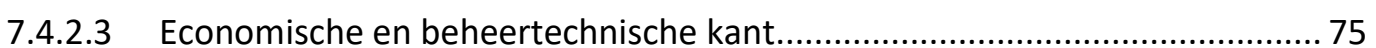

7.4.2.4 Communicatie, afstemmingen en respect .................................................... 76

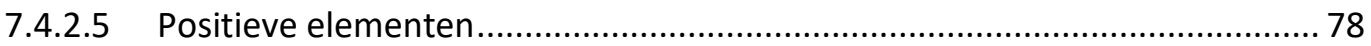

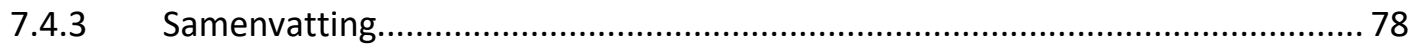

7.5 conclusies socio-economische aspecten.......................................................... 79

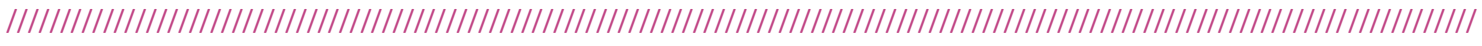


8 algemene conclusies

9 methodologische aandachtspunten voor de toekomst ....................................... 83

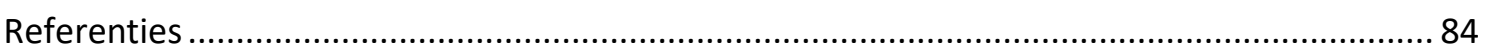

Bijlage 1: Vergelijking van verpachting via licenties en klassieke verpachting ....................... 86

Bijlage 2: Aantal uren aanzit per geschoten ree ....................................................... 87

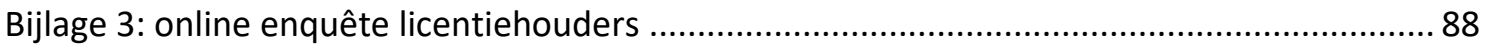




\section{INLEIDING}

Dit rapport geeft de resultaten en bevindingen weer van het proefproject over licentiejacht in de overheidsbossen van Ravels en Arendonk. Het project startte eind 2009 en werd officieel afgerond in 2018. De aanpak op het terrein en de werking van de stuurgroep werden in 2019 en 2020 verdergezet.

Het rapport brengt op een wetenschappelijk onderbouwde manier alle beschikbare informatie omtrent het afschot en de verzamelde bio-indicatoren samen en geeft de resultaten van de analyses van deze data weer. We vergelijken in dit rapport voor bepaalde ecologische parameters de data van het proefproject met waarden en trends voor heel Vlaanderen, de provincie Antwerpen en de omliggende wildbeheereenheden voor dezelfde periode. Daarnaast gaat het rapport ook in op de bevraging van de deelnemers en van de jachtsector. Op basis van alle beschikbare informatie formuleren we enkele conclusies en geven we een aantal aanbevelingen of aandachtspunten voor de toekomst mee.

De aard van het onderzoek, namelijk de wetenschappelijk opvolging van het beheer in één specifiek gebied, houdt automatisch in dat er geen herhalingen in de tijd en/of op andere plaatsen zijn. Er is dus geen sprake van een "controlegebied" waarmee we de licentiejacht in het proefproject vergelijken. Het onderzoek volgt hiermee de filosofie van leren uit praktijkcases. Hierbij worden wetenschap en beheer in alle stappen van het proces (van planning tot evaluatie en bijsturing) tot één geheel geïntegreerd.

Door in verschillende gebieden het beheer en de resultaten ervan wetenschappelijk op te volgen en de ervaringen en opgebouwde kennis samen te brengen en te vergelijken, worden stap voor stap kennislacunes en onzekerheden weggewerkt. Deze nieuwe kennis vormt op zijn beurt de basis voor het uitstippelen van het beheer in andere gebieden en/of voor het bijsturen van het beheer in het gebied zelf. Deze cyclische manier van planning, monitoring, evaluatie, bijsturing, rekening houdend met de onzekerheden en kennislacunes, en de eruit voortvloeiende kennisopbouw vormen de bouwstenen van een adaptief beheer.

Het rapport is dus in eerste instantie beschrijvend en wil een referentiewerk vormen voor toekomstig onderzoek. Om die reden worden op het einde ook enkele methodologische opmerkingen en suggesties gemaakt. 


\section{HET BEGRIP LICENTIEJACHT}

\subsection{MOGELIJKE SYSTEMEN VAN JACHTVERPACHTING OF TOEKENNEN VAN DE TOELATING TOTJAGEN}

Licentiejacht of jacht onder de vorm van afschotlicenties vormt een alternatief voor een systeem van revierpacht. In het laatste geval heeft ofwel de grondeigenaar of in andere gevallen de staat (bv. in Polen) het jachtrecht op bepaalde terreinen. Om te mogen jagen moet een jager dan ofwel zelf eigenaar zijn ofwel het jachtrecht pachten. Klassiek wordt hierbij het jachtrecht op alle soorten gepacht en krijgt de jachtpachter een aantal rechten (mogelijkheid tot jagen binnen de wettelijk toegelaten periodes en met de wettelijk toegelaten middelen) maar ook plichten (vermijden van wildschade, het duurzaam behoud van een gezonde wildstand).

In een ander systeem verwerft een jager aan de hand van een licentie/toelating/tag/permit het recht/toelating om gedurende een bepaalde periode een of meerdere dieren van een of meerdere soorten te schieten in een bepaalde regio of gebied. Zwitserland hanteert dergelijk systeem via afschotlicenties (patentjagd/chasse à patente) in bepaalde regio's (kantons) ${ }^{1}$ (Figuur 1).

In de kantons die gebruik maken van het patentjachtsysteem verwerft de jager tegen betaling een toelating om in het hele kanton (met uitzondering van de jachtvrije zones) een bepaald aantal dieren te schieten gedurende het jachtseizoen. In het kanton Bern moet een jager eerst een basispatent nemen (alle diersoorten behalve watervogels, gemzen, reeën, herten of everzwijnen) en kan dit dan combineren met een licentie specifiek voor het schieten van bijvoorbeeld twee reeën of gemzen².

\footnotetext{
${ }^{1}$ www.bafu.admin.ch/bafu/de/home/themen/biodiversitaet/fachinformationen/massnahmen-zur-erhaltung-undfoerderung-der-biodiversitaet/nachhaltige-nutzung-der-biodiversitaet/jagd.html 


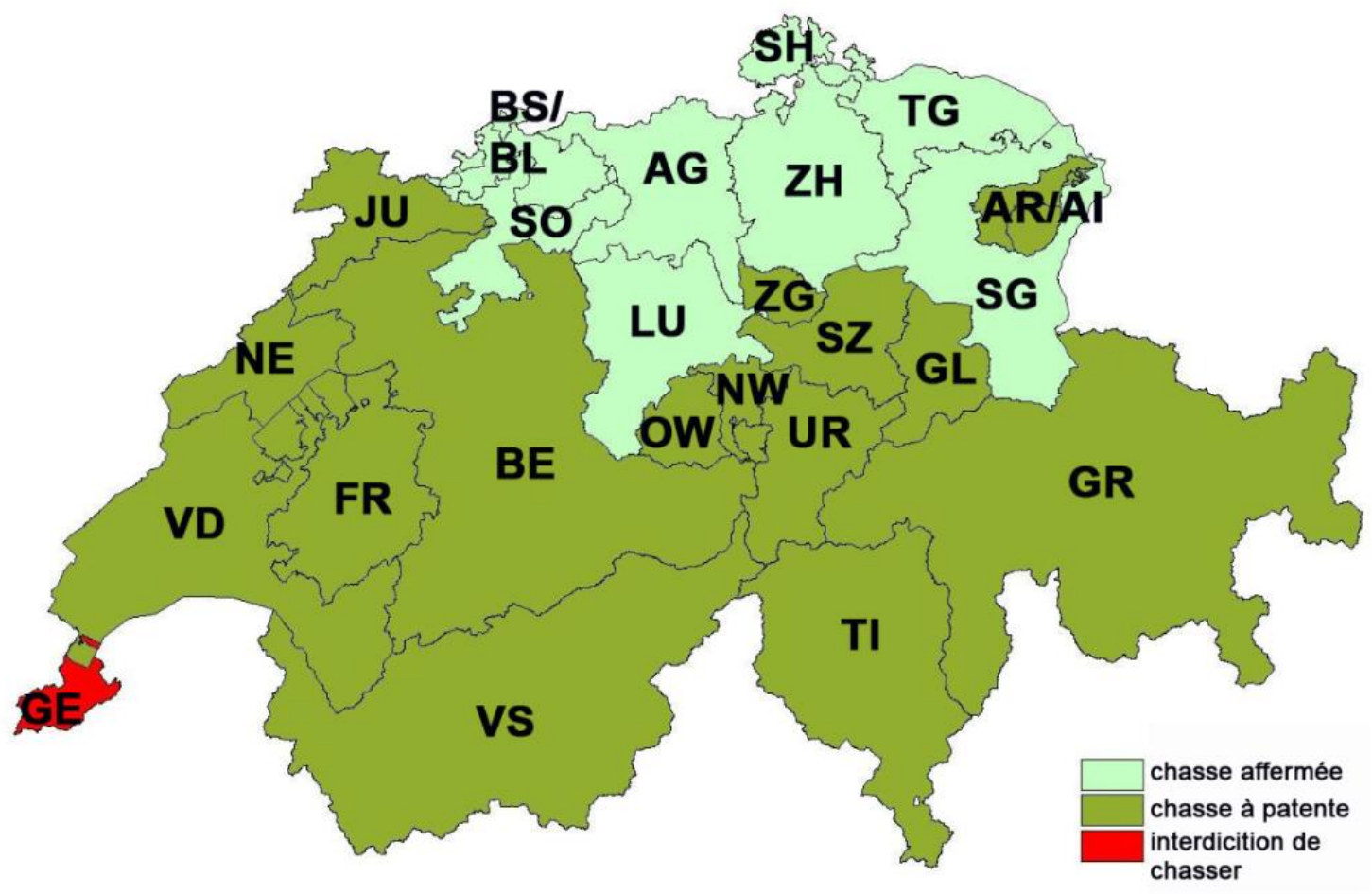

Figuur 1: Aanduiding van kantons met een systeem via afschotlicentie versus deze met een revierjachtsysteem.

Gelijkaardige systemen met 'tags' bestaan ook elders in de wereld zoals in delen van de Verenigde Staten. Daar moet veelal eerst een 'licence' voor een bepaalde staat gekocht worden (te vergelijken met het jachtverlof in Vlaanderen) en daarnaast eventueel nog een 'tag' om een of meerdere dieren te mogen schieten in die staat - al dan niet enkel op overheidsterreinen. De 'tag' kan daarenboven ook nog beperkt zijn tot een bepaalde geslacht/leeftijdscategorie en/of een bepaalde methode (boogjacht/geweer/zwartpoeder) waaraan dan weer bepaalde periodes van het jaar gekoppeld worden.

In heel wat landen bestaat er een gemengde vorm van beide systemen (revierjacht en afschotlicenties). Zo is er het systeem waarbij het jachtrecht door de overheid/grondeigenaar toegekend wordt aan een club of vereniging van jagers, die dan op haar beurt regelt onder welke voorwaarden hun leden (of externen) gebruik kunnen maken van dit recht. Voorbeelden hiervan zijn de waterwildjacht op het Crown Estate in het Verenigd Koninkrijk ${ }^{3}$ en de revierjachtsystemen in de kantons van Zwitserland waar geen 'patentjacht' toegepast wordt. Een ander systeem is dat waarbij de jachtrechthouder in een revierjachtsysteem door middel van afschotlicenties een of meerdere jagers toelating geeft een of meerdere dieren gedurende een bepaalde periode in het gebied te schieten waarop hij het jachtrecht heeft. In Duitsland wordt dit bijvoorbeeld geregeld via de 'jagderlaubnisschein' (vroeger 'Begehungsschein'). Hierbij blijft het jachtrecht bij de grondeigenaar of de persoon die het jachtrecht verworven heeft, maar kan een derde - al dan niet tegen betaling - toelating krijgen dit jachtrecht (mee) uit te oefenen onder bepaalde voorwaarden. Het kan hierbij gaan over de toelating om een of meerdere dieren van een bepaalde soort/leeftijd/geslacht te schieten, aan een of meerdere drukjachten deel te nemen, gedurende een bepaalde periode een aantal dieren te schieten of

${ }^{3}$ www.bernerjagd.ch/jagd-im-kanton-bern/jagdliche-praxis/ ///////////////////////////////////////////////////////////////////////////////////////////////////////////////////////////////// 
over de toelating om het volgende jaar/jaren een deel van de jacht als 'Pirschbezirk' ${ }^{4}$ te gebruiken. In dat laatste geval kan dit bijvoorbeeld voor alle grofwildsoorten zijn. In veel gevallen maakt de jachtrechthouder (bijvoorbeeld de lokale regiobeheerder ('forstverwaltung')) gebruik van meerdere van deze mogelijkheden naast elkaar in hetzelfde gebied. Daarnaast wordt een deel van de populatieregulatie in Duitsland soms ook door het eigen overheidspersoneel uitgevoerd. Deze toelatingen worden ook niet steeds openbaar verpacht maar kunnen 'bevraagd' worden bij de lokale regiobeheerder. Ook private 'eigenjachten ${ }^{5}$ ' kunnen gebruik maken van dergelijke systemen om de 'uitoefening van het jachtrecht' aan derden door te geven.

In Frankrijk maakt bijvoorbeeld ook het Office Nationale des Forêts (ONF) gebruik van afschotlicenties in bepaalde overheidsbossen en natuurgebieden die het agentschap beheert ${ }^{6}$. Ook bij het ONF zijn er verschillende vormen van licenties mogelijk. Het kan hierbij gaan over de deelname aan een druk- of drijfjacht, jagen onder begeleiding van een gids of het huren van de mogelijkheid tot jagen in een specifiek lot gedurende een bepaald jachtseizoenen.

In Wallonië tenslotte wordt het systeem van 'chasse à licence' in bepaalde overheidsgebieden reeds een aantal jaren toegepast. Het werd aanvankelijk in een aantal gemeente- en domeinbossen in Elsenborn toegepast (1994) en later uitgebreid naar andere gebieden in de Oostkantons. Meer recent (2015) werd het ook toegepast op een deel van het Forêt d'Anlier.

Twee kenmerken typisch voor de toepassing van het systeem van 'chasse à licences' in het Waals Gewest zijn:

- De publieke instanties (Waals Gewest of gemeenten) behouden zelf het jachtrecht en de houden de jachtorganisatie in handen, maar laten het afschot uitvoeren door de mensen die een afschotlicentie genomen hebben.

- In veel gevallen is een deel van de afschotlicenties vooraf reeds voorbehouden voor inwoners van de gemeenten waarin de bossen zich situeren.

\subsection{DEFINITIES EN BEGRIPPEN}

Omdat er tal van termen door elkaar gebruikt kunnen worden én omwille van de verschillende mogelijke nuances in de verschillende talen geven we hieronder de definities weer zoals gehanteerd in dit rapport.

Terreineigenaar: de persoon of organisatie die eigenaar is van het terrein.

Terreinbeheerder: De persoon of organisatie die een terrein beheert.

Jachtrecht: het recht dat van toepassing is op de uitoefening van de jacht in een bepaald gebied.

Jachtrechthouder : de persoon of organisatie die het jachtrecht heeft. Dit kan de terreineigenaar zijn, de overheid of een persoon of organisatie die het jachtrecht pacht van de terreineigenaar of overheid.

\footnotetext{
${ }^{4}$ Deel van een jachtgebied warvoor de jachtrechthouder a an een derde de toelating geeft om er voor een bepaalde periode te jagen op één of meerdere soorten (al dan niet beperkt in aantal en in methode)

${ }^{5}$ In Duitsland dient een terrein voldoende groot te zijn om als eigenjacht te bestaan. In het andere geval zijn ze terreineigenaars wettelijk verplicht hun terreinen in te voegen in de gemeenschapsjacht)

${ }^{6}$ www.chasse.onf.fr

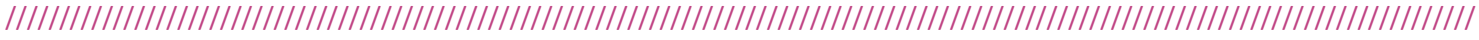


Toelating tot het gebruik van het jachtrecht: een persoon of organisatie die van de jachtrechthouder de toelating krijgt gebruik te maken van zijn jachtrecht, zonder daarbij zelf het jachtrecht te verwerven.

Jachtverlof: het wettelijk vereiste verlof dat voor heel Vlaanderen geldig is gedurende een jachtseizoen en een van de noodzakelijke voorwaarden is om te kunnen jagen in Vlaanderen.

Afschotlicentie: de toelating om gedurende een bepaalde periode, in een bepaald gebied, onder bepaalde voorwaarden, een of meerder dieren van een of meerdere soorten te schieten of te proberen te schieten. Voor dit rapport hanteren we de afschotlicentie als een toelating die gebonden is aan een persoon en niet overdraagbaar is naar derden of met hen gedeeld kan worden. Voor dit rapport gaan we er ook van uit dat in geval van het toepassen van afschotlicenties, het jachtrecht bij de eigenaar of terreinbeheerder blijft en dus enkel de toelating tot het schieten van een aantal dieren aan iemand gegeven wordt (cfr. Wallonië).

Licentiehouder: iemand die beschikt over een afschotlicentie voor een bepaalde periode en een bepaald gebied.

Langlopende verpachting: een klassieke verpachting van het jachtrecht waarbij een persoon of groep van personen het jachtrecht pacht voor een specifiek gebied en dit voor een periode van 3/6/9 jaar en hierbij de rechten en plichten krijgt zoals deze bepaald zijn in het Jachtdecreet.

Kortlopende verpachting: een verpachting van het jachtrecht waarbij een persoon of groep van personen het jachtrecht pacht voor een specifiek gebied en dit voor een periode van maximaal 1 jachtseizoen en hierbij de rechten en plichten krijgt zoals deze bepaald zijn in het Jachtdecreet.

Onafhankelijke jagers: voor dit onderzoek werden ook gegevens opgevraagd van jagers buiten het proefgebied. Om naar deze jagers te verwijzen gebruiken we in dit rapport de term onafhankelijke jagers.

Voor de eenduidigheid van het rapport worden verpachtingen waarbij het jachtrecht gepacht wordt maar beperkt in de soorten, de dagen dat er gejaagd mag worden, de methoden die gebruikt mogen worden (bv. geen bersjacht) en alle mogelijke andere beperkingen van het jachtrecht waardoor de pachter niet het jachtrecht ten volle kan benutten cfr.de algemene bepalingen van het Jachtdecreet, hier niet als een speciale vorm van verpachting vermeld. Deze vormen van verpachting bevinden zich immers ergens in een continuüm van de verpachting van het jachtrecht in een reviersysteem naar een systeem via licenties. De auteurs doen met deze beslissing geen uitspraak over de juridische aspecten van deze jachtverpachtingen in Vlaanderen zoals die actueel bestaan.

Deze gebruikte definities staan verder los van de actuele juridische betekenis die in de verschillende landen of systemen samenvallen met deze termen.

\subsection{DE KEUZE VOOR HET GEBRUIK VAN AFSCHOTLICENTIES IN EEN REVIERJACHTSYSTEEM}

Het gebruik van afschotlicenties (tags, patentes) kan zoals hoger aangehaald in een bepaald land of regio de klassieke manier zijn om de jacht te organiseren. Anderzijds kan het dus ook een manier zijn voor een grotere terreineigenaar en/of jachtrechthouder in een klassiek reviersysteem, zoals Vlaanderen kent, om derden toelating te geven gebruik te maken van zijn of haar jachtrecht. Verschillende mogelijke redenen kunnen hiervoor de motivatie zijn; 
- Het verwerven van inkomsten door het verkopen van afschotlicenties, bijvoorbeeld in het kader van jachttoerisme. Dit wordt veel toegepast in het Verenigd Koninkrijk.

- De grotere controle over of de mogelijkheid tot bijsturen van de uitoefening van de jacht in vergelijking met de klassieke langlopende jachtverpachting.

- De mogelijkheid om de doelstellingen van het faunabeheer zelf te bepalen als terreineigenaar en sneller te kunnen bijsturen.

- De mogelijkheid om tal van bijkomende bepalingen (tijd, ruimte, soorten etc.) te laten gelden.

- Het feit dat men zelf het jachtrecht behoudt en op die manier als terreineigenaar/beheerder niet alleen het beheer van de vegetatie en recreatie kan sturen, maar dus ook het faunabeheer in eigen regie behoudt.

- Het aan een veel groter aantal mensen kunnen aanbieden van de mogelijkheid om te jagen in het gebied. Dit niet alleen door verschillende kortlopende jachtperiodes te voorzien, maar ook omdat een afschotlicentie goedkoper is dan het pachten van het jachtrecht voor het volledige gebied.

- De mogelijkheid om een deel van de licenties voor te kunnen behouden aan bepaalde groepen in de maatschappij (bv. inwoners van een bepaalde gemeente (Wallonië), jongjagers (Duitsland), veteranen (VS)).

- De andere relatie die kan ontstaan tussen publieke instelling (overheid) als gastheer of organisator en de licentiehouders (jachtgast in het gebied).

Veel van deze elementen kunnen juridisch gezien in Vlaanderen ook geregeld worden door het lastenboek van een klassieke verpachting. Het opleggen van voorwaarden of beperkingen betekent dan in de feiten wel dat het jachtrecht niet in zijn volledigheid verpacht wordt. 


\section{AANLEIDING PROJECT}

In 2009 maakten het Agentschap voor Natuur en Bos (ANB) en het Instituut voor Natuur- en Bosonderzoek (INBO) een overeenkomst op voor een onderzoek naar "Licentiejacht als wildbeheerinstrument in de domeinbossen Gewestbos Ravels en de Hoge Vijvers Arendonk." (ANB/BL-FF/WILDBEHEER/4/2009). Deze overeenkomst had tot doel de taakverdeling af te spreken voor een project waarbij beide instellingen samen de haalbaarheid, de mogelijkheden en de voor- en nadelen van licentiejacht als wildbeheerinstrument in Vlaanderen evalueren. De praktische organisatie op het terrein en de jachtadministratie werd toegekend aan het $A N B$, het uitwerken van de monitoringsprotocols, de data-analyse en de rapportering aan het INBO.

Deze overeenkomst bepaalde ook dat er een stuurgroep samengesteld moest worden waarin, naast het ANB en het INBO, ook externe experts zetelen en dat die stuurgroep minstens één keer per jaar zou samenkomen. Elk van de aangrenzende WBE's (De Vart, De Aa-Ravels, Tulderheide) is vertegenwoordigd in deze stuurgroep (Figuur 2). Op dit overleg lichtte het INBO telkens de monitoringsgegevens van het laatste jaar in relatie tot de voorgaande jaren toe.
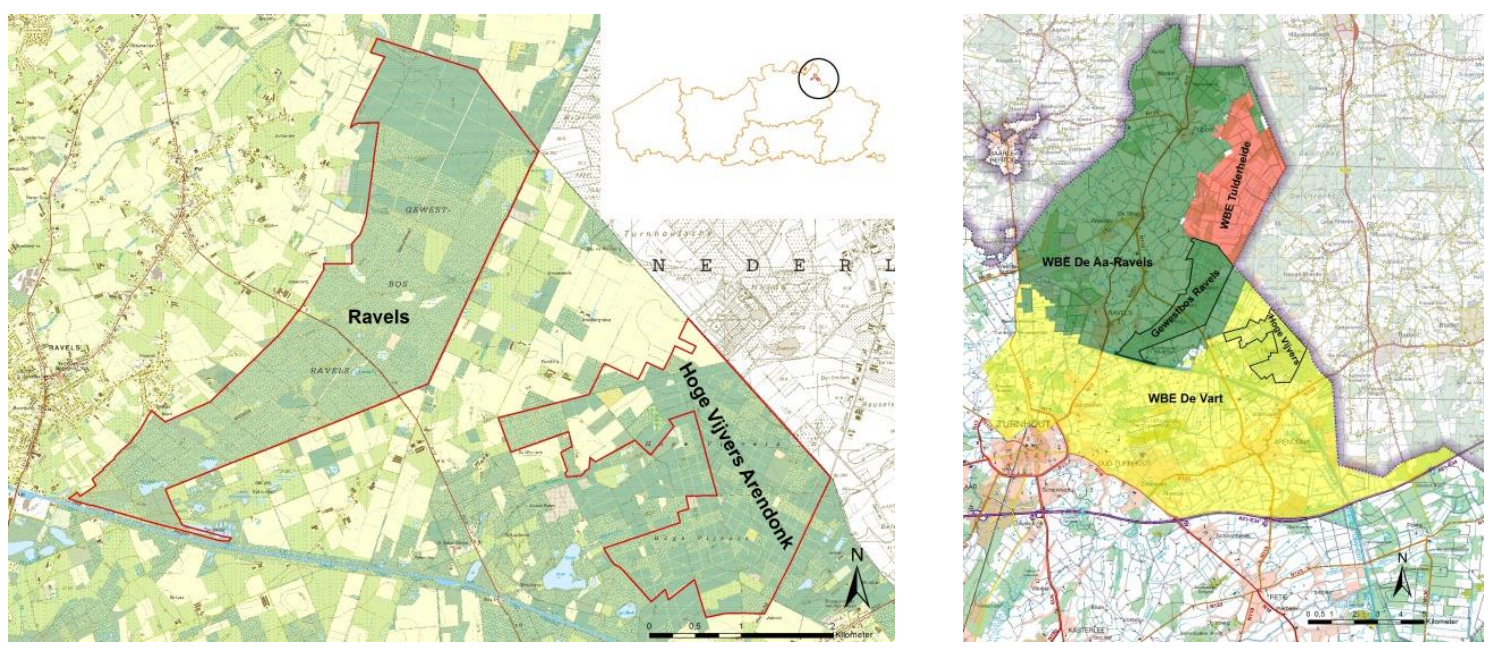

Figuur 2: Situering van het proefgebied in Vlaanderen (links) en de aangrenzende WBE's (rechts). 
Een aantal concrete onderzoeksvragen werden bij aanvang van het project naar voor geschoven.

1. In welke mate lukt het aan de hand van licentiejacht (beter) de reepopulatie te reduceren tot een niveau waarbij de natuurlijke verjonging zich kan vestigen en tegelijkertijd het duurzaam voortbestaan van een gezonde reewildpopulatie zowel als de mogelijkheid tot een duurzaam afschot naar de toekomst toe gegarandeerd blijven?

2. Gebeurt het afschot bij licentiejacht efficiënter dan bij klassieke verpachtingen?

3. Is het afschot onder licentiejacht minder selectief dan bij klassieke verpachtingen?

4. Is er een beter samenwerking tussen de overheid en lokale belanghebbenden (deelnemende jagers) dan bij klassieke verpachtingen?

5. Is er een maatschappelijk draagvlak bij zowel de jachtsector als bij het breder publiek voor deze vorm van jachtverpachting?

6. Welke extra kosten/inspanningen brengt deze vorm van verpachting mee voor het ANB?

De algemene, overkoepelende vraag is in welke mate licentiejacht beter of slechter tegemoetkomt aan de vooropgestelde beheerdoelstellingen in vergelijking tot de klassiek gangbare manier van verpachten. Het beheer van overheidsbossen houdt naast het ecologisch aspect ook rekening met de recreatieve en economische functie van het bos en probeert deze verschillende functies zo goed mogelijk op elkaar af te stemmen. Dat jacht in dat verhaal een beheerinstrument is, maar tegelijk ook deel uitmaakt van de recreatieve en economische functie van het bos, mag hierbij niet uit het oog verloren worden.

Wanneer de bovenvermelde vragen gesitueerd worden binnen de oefening rond het beheeren beleidsdoelstellingenkader voor wildbeheer in Vlaanderen (Casaer and Huysentruyt, 2017), blijkt dat ze zich zowel op het niveau van de finale als van de middelendoelstellingen situeren, maar ook dat een deel ervan duidelijk procesdoelstellingen zijn (zie onderstaande opsomming).

Onderstaand overzicht situeert de doelstellingen binnen deze algemenere doelstellingenoefening. Zoals steeds moet hierbij opgemerkt worden dat niet alle weerhouden doelstellingen even zwaar doorwegen en sommige middelendoelstellingen kunnen bijdragen aan verschillende hoger gelegen finale doelstellingen (Gregory et al., 2012; Runge et al., 2013).

Finale / middelen doelstellingen:

1. Maximaliseren van het voortbestaan van inheemse niet-wild soorten, hun leefgebieden, waardevolle habitats en ecosysteemfuncties.

a. Voor Ravels en Arendonk zijn dit enerzijds een aantal aandachtssoorten van de Habitat- en Vogelrichtlijn, en anderzijds het herstel van het "Oude EikenBerkenbossen op zeer voedselarm zand - habitattype 9190 ", naast het meer in het algemeen realiseren van een omvorming naar meer loofboomsoorten, waar mogelijk zonder de inzet van rasters. Het beperken van de negatieve impact van de aanwezige reepopulatie op de natuurlijke en kunstmatige verjonging vormt hierbij een cruciale middelendoelstelling waaraan de licentiejacht moet bijdragen.

2. Maximaliseren van voortbestaan van inheemse wildsoorten, hun leefgebieden en ecosysteemfuncties.

a. Specifiek betreft het hier het garanderen van het voortbestaan een gezonde reepopulatie in de beide boscomplexen, zowel als de mogelijkheid de soort te 
observeren en te bejagen (zie 3), maar ook de andere ecosysteemfuncties van het bosgebied (zoals recreatie en zie 1 ).

3. Maximaliseren van de mogelijkheden voor consumptief en niet-consumptief gebruik van wildsoorten.

a. Voor dit project ging het over de mogelijkheid om reewild duurzaam te kunnen bejagen alsook om de mogelijkheid om reeën te kunnen observeren als recreant/wandelaar.

4. Maximaliseren van private en publieke economische voordelen.

a. Maximaliseren van een duurzame oogst (zie 3a).

b. Minimaliseren van de negatieve impact van de reeën op de bosverjonging en/of de kosten voor preventieve maatregelen (zie ook 1a).

5. Maximaliseren van publieke veiligheid en gezondheid

a. Minimaliseren van het risico op verkeersongelukken met reeën.

b. Minimaliseren van het gevoel van onveiligheid.

6. Minimaliseren van de kosten van het wildbeheer voor de overheid en private personen

a. Minimaliseren van kosten voor de overheden

i. Minimaliseren van kosten voor preventieve maatregelen zoals rasters rond bosverjonging (zie hoger).

ii. Minimaliseren van kosten/baten balans gekoppeld aan het uitvoeren van het wildbeheer op zich (organisatie/controle).

7. Minimaliseren van onnodig dierenleed.

Proces- en strategische doelstellingen:

8. Maximaliseren van maatschappelijk draagvlak voor het gevoerde reewildbeheer.

a. Maximaliseren van de betrokkenheid tussen en samenwerking met lokale belanghebbenden bij de besluitvorming.

b. Minimaliseren van de kosten van het wildbeheer.

c. Maximaliseren van de aanwezigheid, competentie en verantwoordelijkheid bij belanghebbenden.

d. Adaptief (impact)beheer als basis voor het beheer.

i. Maximaliseren van het inzetten op een iteratief proces in het kader van het bijsturen van het beheer op basis van monitoringgegevens.

ii. Maximaliseren van onderbouwing van het beheer op basis van wetenschappelijke data. 


\section{GEBIEDEN EN CONCRETE TOEPASSING VAN AFSCHOTLICENTIES IN HET PROEFPROJECT}

\subsection{SITUERING GEBIED}

Het proefproject vond plaats in bosplaats 'Ravels' en bosplaats 'De Hoge Vijvers Arendonk', beide gelegen in de provincie Antwerpen (Figuur 2).

\subsubsection{Gewestbos Ravels}

Het domeinbos 'Gewestbos Ravels' omvat de bosplaatsen Ravels en Overheide en is eigendom van het Vlaamse gewest, Agentschap voor Natuur en Bos. Wanneer in dit rapport verwezen wordt naar Ravels betreft het enkel de bosplaats Ravels. De bosplaats Ravels meet 833 hectaren.

Binnen deze bosplaats is het reliëf relatief vlak (30-35 mTAW). De bodem bestaat er uit een complex van droge en natte zandgronden. Vroeger bestond de bosplaats hoofdzakelijk uit vennen, momenteel bestaat de bedekking uit gemengd naald- en loofhout (47\%), naaldhout $(36 \%)$, loofhout (9\%) en open ruimte (7\%). De totale beboste oppervlakte beslaat 765 ha (ANB, 2008b). Ravels heeft een grote variatie aan boomsoorten en bestandsleeftijden, en diverse open ruimten en gesloten bos wat uitzonderlijk is voor een vrij jong bos op zandgrond in de Kempen. Dit biedt een afwisselend landschapsbeeld, diverse fauna en een breed scala van houtproducten die een belangrijke invulling geven aan het mozaïekcyclusconcept van de beheervisie voor openbare bossen (ANB, 2008b).

De overgebleven vennen zijn opgenomen in Habitatrichtlijngebied "Vennen, heiden en moerassen rond Turnhout" en een aantal bestanden zijn opgenomen in het VEN-gebied "Het Turnhouts vennengebied". Het grootste deel van de bosplaats maakt ook deel uit van het Vogelrichtlijngebied "Arendonk, Merksplas, Oud-Turnhout, Ravels en Turnhout" (ANB, 2008b).

Ravels heeft een multifunctionele beheerdoelstelling waarin alle bosfuncties (economische functie, sociale \& educatieve functie, milieubeschermende functie, ecologische functie, bosreservaten (Bosdecreet, 1990))moeten aan bod komen en gelijkwaardig zijn. Een ruimtelijke zonering van bosfuncties wordt toegepast waar nodig op basis van de uitgangssituatie en de opportuniteiten om bepaalde functies te versterken. Indien een bepaalde bosfunctie een negatieve impact heeft op een andere, geldt binnen het Habitatrichtlijngebied de volgorde ecologie, recreatie/educatie, economie(ANB, 2008b).

De ecologische bosfunctie wordt verwacht om de meeste vooruitgang tegen 2030 te boeken. Daarnaast worden de economische, sociale en educatieve functies bestendigd en geoptimaliseerd. De wetenschappelijke functie zal verder worden gezet zoals voorheen. Aangezien de milieubeschermende functie afhankelijk is van het omliggende landgebruik, kan de negatieve impact van toenemende bebouwing, verkeer en intensieve landbouw niet louter door maatregelen in het domeinbos worden gecompenseerd, zelfs al wordt getracht om deze 
negatieve impact the milderen door bosvorming en -omvorming, natuurontwikkeling en buffering aan de randen.

\subsubsection{Hoge Vijvers Arendonk}

De bosplaats 'Hoge Vijvers Arendonk' is eigendom van het Vlaamse Gewest, Agentschap voor Natuur en Bos (ANB) en beslaat ongeveer 510 hectare. In dit rapport verwijzen we naar dit gebied steeds als Arendonk.

Het reliëf van de bosplaats is relatief vlak (30-35 mTAW). De bodem bestaat vooral uit zandgrond en bevat ook enkele natte zones. Hoge Vijvers bestaat uit naaldhout (66\%), gemengd naald- en loofhout (10\%), loofhout (10\%) en open ruimte $(12 \%)$ en heeft actueel een beboste oppervlakte van 410 hectare(ANB, 2008a). De meest karakteristieke eigenschap in deze bosplaats is de aanwezigheid van kleine, verspreide, rijke bosbestanden met inheemse soorten naast schrale open plekken in een grote, schijnbaar homogene naaldbosaanplanting. Hiernaast zijn ook het omvangrijke en fijnmazige raster van boswegen (100 bij $100 \mathrm{~m}$ ), een ingesloten akkerlandblok, open akkerland en parkachtig bos kenmerkend voor de bosplaats (ANB, 2008a).

Hoge Vijvers maakt geen deel uit van een internationale of nationale beschermingszone. Het ligt wel in waterwingebied.

Net zoals de bosplaats Ravels, heeft de bosplaats Hoge Vijvers een expliciet multifunctionele doelstelling. Alle bosfuncties moeten aan bod komen en zijn gelijkwaardig. Hierbij is een ruimtelijk zonering van functies geen doelstelling, hoewel dit wel kan worden toegepast op basis van bestaande uitgangssituaties of opportuniteiten om bepaalde functies te versterken.

De ecologische bosfunctie wordt verwacht om de meeste vooruitgang te boeken tegen 2027 . Daarnaast worden de economische, sociale en educatieve functies bestendigd en geoptimaliseerd. Net zoals bij Ravels kan binnen de milieubeschermende functie de negatieve impact van omliggend landgebruik niet worden goedgemaakt door maatregelen in het domeinbos, al wordt ook hier getracht om deze effecten te milderen door bosomvorming, natuurontwikkeling en buffering aan de randen(ANB, 2008a). 


\section{$4.2 \quad H I S T O R I E K$ VAN DE JACHT IN BEIDE DOMEINBOSSEN}

Tot 1992 was de jacht in Ravels bijna continu verpacht via klassieke verpachting. Tussen 1992 en 2000 vond geen jacht plaats. In 2000 werd het noordelijke deel opnieuw verpacht voor een jaarlijks bedrag van 6.445 euro en vanaf 2005 werd ook het zuidelijke deel verpacht voor een prijs van 3.125 euro. Beide verpachtingen liepen in 2009 af. Deze verpachting gebeurde toen al met de bedoeling de reepopulatie te verkleinen met het oog op natuurlijke verjonging van loofhout (ANB, 2008b). Enkel de afschotgegevens van 2001 t.e.m. 2006 zijn gekend (Tabel 1).

Tabel 1: Historische afschotgegevens Ravels

\begin{tabular}{llll}
\hline jaar & geit & bok & kits \\
\hline 2001 & 0 & 5 & 0 \\
2002 & 8 & 5 & 15 \\
2003 & 8 & 4 & 13 \\
2004 & 10 & 5 & 14 \\
2005 & 8 & 5 & 12 \\
2006 & 4 & 4 & 8 \\
\hline
\end{tabular}

Ook in Arendonk was er lange tijd geen verpachting. In 1999 werd de jacht er opnieuw verpacht voor een jaarlijks bedrag van 17.352 euro. De jachtpacht werd in 2001 opgezegd wegens het illegaal uitzetten van fazanten. Van die 2 jaar zijn er geen afschotcijfers beschikbaar.

\subsection{TOEPASSING VAN AFSCHOTLICENTIES IN HET PROEFPROJECT}

In dit licentiejachtproject werd steeds gewerkt met afschotlicenties geldig voor één of twee korte afschotperiodes in de winter (geiten en kitsen) of de zomer (bokken). Bij aanvang van het project in 2010 waren er nog geen everzwijnen aanwezig in de regio en betroffen de afschotlicenties dus enkel reewild.

De afschotlicenties werden steeds op naam toegekend en waren niet overdraagbaar. De licentiehouder kon zowel een afschotlicentie nemen voor de winter als voor de zomer binnen hetzelfde jaar, maar kon niet tegelijkertijd een afschotlicentie voor Ravels én voor Arendonk nemen.

Afschotlicenties werden toegekend aan de hoogste bieder. De biedingen konden zowel vooraf schriftelijk gebeuren als op de dag van de openbare verpachting zelf. Het aantal afschotlicenties bleef niet gedurende de volledige periode van het project constant: om de kansen voor het realiseren van het volledig voorziene afschot te maximaliseren, is doorheen de loop van het project het aantal afschotlicenties verhoogd (Tabel 2). 
Tabel 2: Aantal afschotlicenties die jaarlijks verpacht werden sinds de start van het proefproject

\begin{tabular}{|c|c|c|c|c|}
\hline Aantal licenties per jaar & Ravels & & Arendonk & \\
\hline & Winter & Zomer & Winter & Zomer \\
\hline 2010 & 5 & 5 & 3 & 3 \\
\hline 2011 & 5 & 3 & 3 & 3 \\
\hline 2012 & 5 & 5 & 3 & 3 \\
\hline 2013 & 5 & 5 & 3 & 3 \\
\hline 2014 & 8 & 8 & 4 & 4 \\
\hline 2015 & 8 & 8 & 4 & 4 \\
\hline 2016 & 8 & 8 & 4 & 4 \\
\hline 2017 & 8 & 8 & 4 & 4 \\
\hline 2018 & 8 & 8 & 4 & 4 \\
\hline 2019 & 10 & 8 & 6 & 4 \\
\hline
\end{tabular}

Ook het aantal dagen dat een afschotlicentie geldig was, is doorheen de loop van het project enkele keren aangepast. Dit zowel als gevolg van aanpassingen in de wetgeving als op basis van de input van deelnemende jagers op het jaarlijks evaluatiemoment met ANB. Zowel in de winter als in de zomer werd steeds de mogelijkheid voorzien voor één of meerdere gemeenschappelijke aanzitten om de kans op het vervolledigen van het afschot te vergroten. Bij een gemeenschappelijke aanzit kon elke houder van een afschotlicentie in het begin telkens twee en in de latere jaren telkens één extra jager(s) uitnodigen om deel te nemen aan de aanzit.

Sinds 2014 mocht de licentiehouder gedurende de periode van de aanzitjacht ook everzwijnen schieten en werd deelname aan drukjachten op everzwijnen opgenomen als deel van de afschotlicentie. 


\section{JACHT EN DE GEVOLGEN ERVAN}

\subsection{AFSCHOTTOEKENNING EN REALISATIE}

\subsubsection{Projectgebied}

Het reewildafschot werd toegekend op basis van de filosofie achter een driejarenafschotplan voor reewild(Huysentruyt and Casaer, 2012). Bij opstart van het pilootproject was deze aanpak nog niet systematisch ingevoerd in heel Vlaanderen, maar gezien rond het driejarenafschotplan reeds enkele jaren een proefproject liep en positief ervaren werd, werd beslist deze werkwijze ook in dit proefproject toe te passen. Hierbij werd wel beslist het eerste jaar (2010) een afschot toe te kennen als test en pas vanaf het tweede jaar (2011) effectief met periodes van drie jaar te werken. De drie driejarenperiodes waren 2011 - 2013, $2014-$ 2016 en 2017 - 2019. Omdat de lopende periode voor het driejarenafschotplan voor de rest van Vlaanderen afliep in 2020, besliste de stuurgroep om voor 2020 hetzelfde afschot als in 2019 toe te kennen. Voor Arendonk werd na het eerste jaar het toegekende afschot verhoogd tot 6 bokken, 6 geiten en 12 kitsen (totaal $=24$ stuks). Dit aantal werd vervolgens gedurende de hele periode behouden. Voor Ravels werd het afschot in 2011 verhoogd tot 10 bokken, 10 geiten en 20 kitsen. Op basis van de resultaten van de monitoring van de bio-indicatoren en van de populatietrend (zie 5.3), werd dit afschot na drie jaar, in 2014, verder verhoogd tot 12 bokken, 14 geiten en 22 kitsen (Figuur 3).

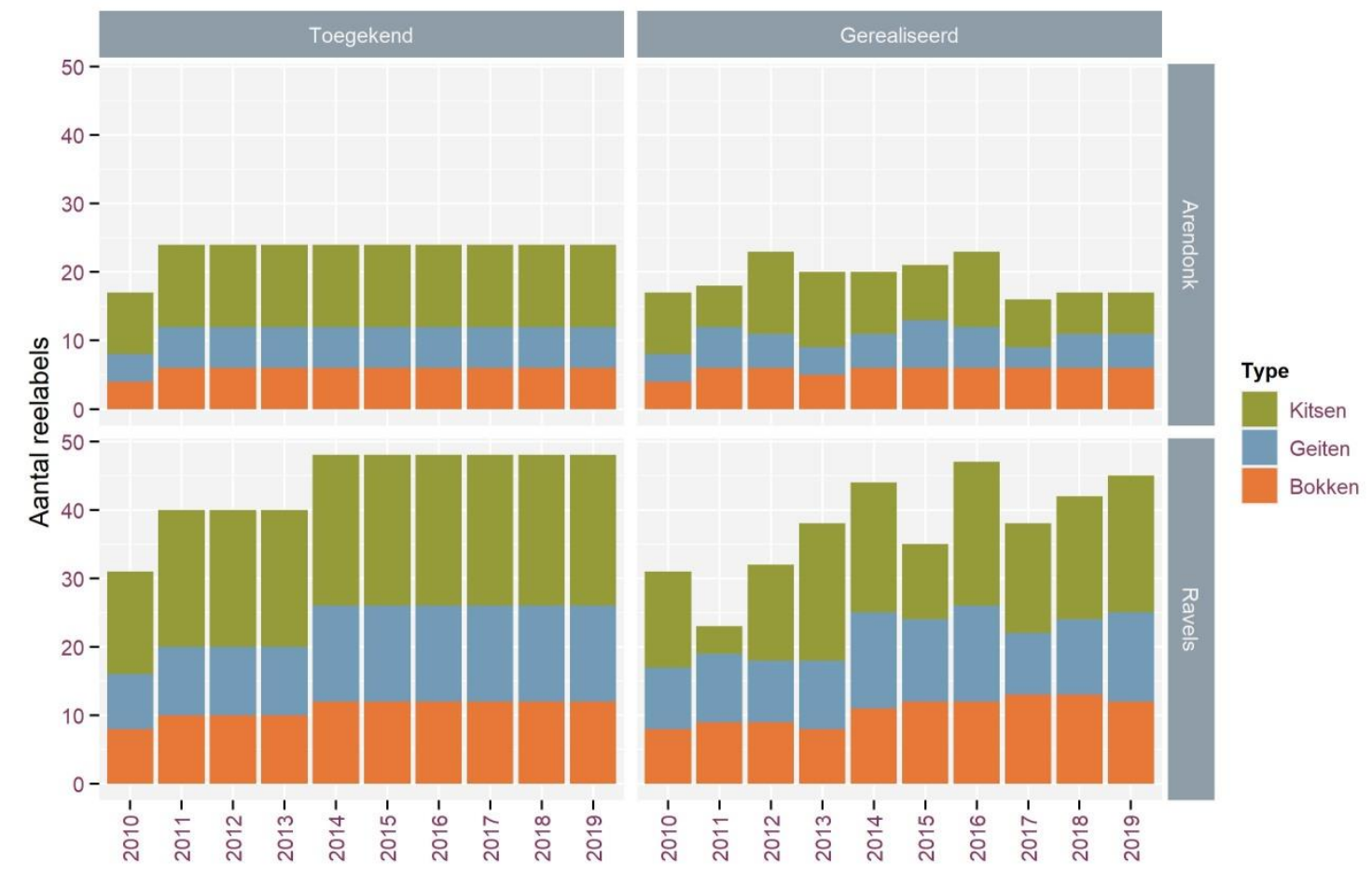

Figuur 3: Aantal toegekende reelabels en realisaties voor Ravels en Arendonk voor de periode 2010 2019

Figuur 3 geeft voor beide gebieden, per jaar en per labeltype (bok, geit, kits) het aantal effectief geschoten dieren weer. Over de hele periode blijkt hieruit dat het gemiddeld afschot voor de bokken bijna $100 \%$ bedroeg. 
Voor de geiten lag de realisatiegraad iets lager (respectievelijk $92,4 \%$ en $86,7 \%$ voor Ravels en Arendonk) en voor de kitsen nog wat lager (respectievelijk 76,1\% en 73,3\%).

Tabel 3 geeft de minimale en de maximale realisatiegraad voor elk gebied en elk labeltype over de volledige periode weer. We merken hierbij op dat in bepaalde jaren de realisatiegraad meer dan $100 \%$ bedroeg. Dit was mogelijk omdat er gebruik gemaakt werd van een reservelabel dat ANB ter beschikking had om in te zetten bij verkeerd ingeschat afschot wanneer er geen labels voor die categorie meer beschikbaar waren.

Tabel 3: Samenvattende gegevens van de afschotrealisaties in beide gebieden en voor elk labeltype voor de volledige periode (2010-2019) (SD = standaard deviatie)

\begin{tabular}{llllllll}
\hline Type & Gebied & Gemiddelde & N & SD & Betr.interval & Min & Max \\
\hline Bokken & Arendonk & 98.33 & 10 & 5.27 & 3.27 & 83.33 & 100.00 \\
Bokken & Ravels & 96.83 & 10 & 8.87 & 5.50 & 80.00 & 108.33 \\
Geiten & Arendonk & 86.67 & 10 & 18.92 & 11.73 & 50.00 & 116.67 \\
Geiten & Ravels & 92.39 & 10 & 13.61 & 8.44 & 64.29 & 112.50 \\
Kitsen & Arendonk & 73.33 & 10 & 21.08 & 13.07 & 50.00 & 100.00 \\
Kitsen & Ravels & 76.06 & 10 & 24.67 & 15.29 & 20.00 & 100.00
\end{tabular}

\subsubsection{Vergelijking met de rest van Vlaanderen, de provincie Antwerpen en de omliggende wildbeheereenheden}

Om een idee te krijgen van de afschotrealisatie binnen het licentiejachtproject (Ravels en Arendonk samen) ten opzichte van de rest van Vlaanderen, werd de vergelijking van de gemiddelde afschotrealisatie met de omliggende WBE's (Bos en Duin Kasterlee, De Vart, Groot-Lille, Merksplas, Retie, De AA, Dessel, Klei en zand, Postel Jacht en Natuur, Tulderheide), met de hele provincie Antwerpen en met Vlaanderen gemaakt. Figuur 4 toont dat de afschotrealisatie binnen de licentiejacht bijna altijd boven de gemiddelde afschotrealisatie van de omliggende WBE's, de provincie Antwerpen en Vlaanderen ligt. In 2011, 2017, 2018 lag de gemiddelde realisatie van de omliggende WBE's hoger dan deze van de licentiejacht. 


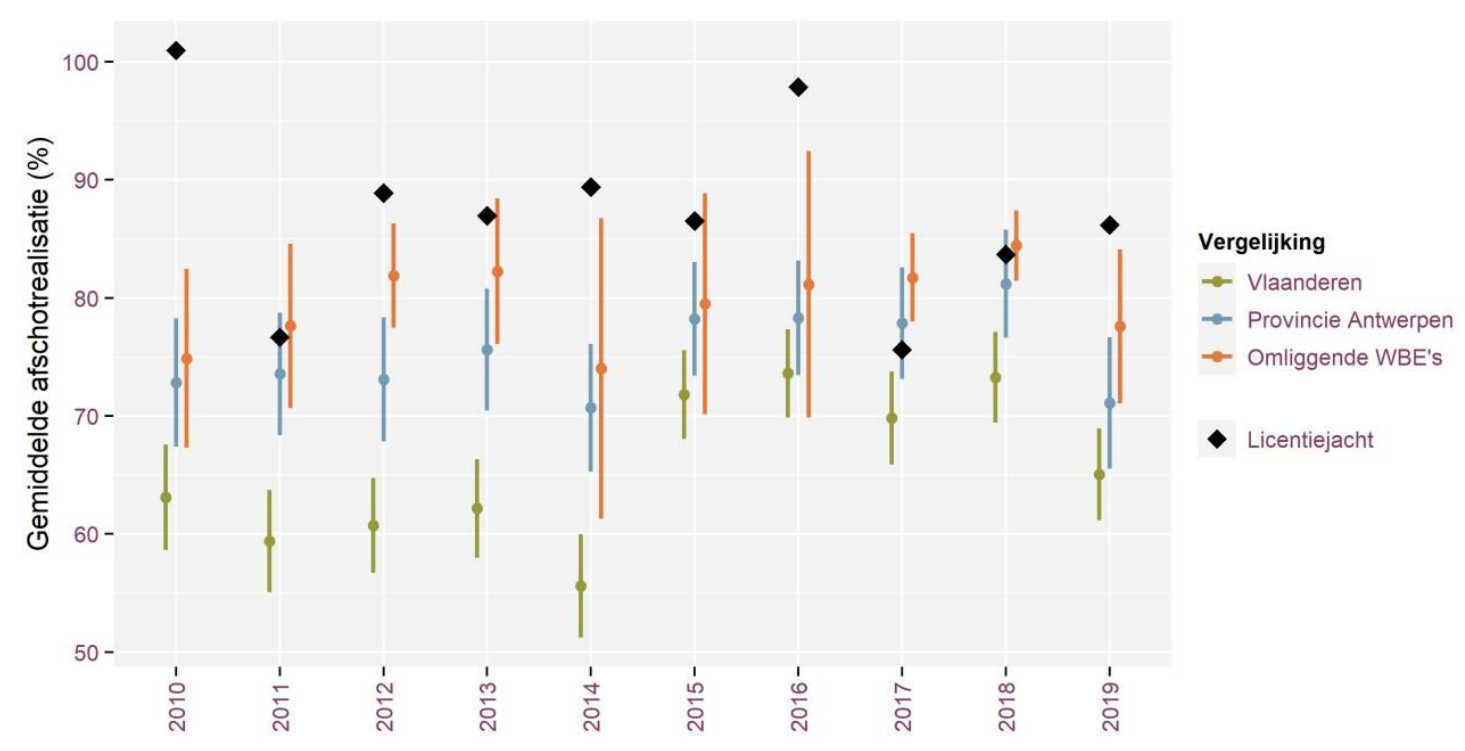

Figuur 4: Gemiddelde afschotrealisatie (\%) binnen het licentiejachtproject in vergelijking met omliggende WBE's, de provincie Antwerpen en Vlaanderen doorheen de jaren. Hierbij duiden de punten het gemiddelde aan en de lijnen de betrouwbaarheidsintervallen.

\subsubsection{Conclusie van de afschottoekenning en realisatie}

Doorheen het project verhoogde het toegekende afschot. In Arendonk gebeurde dit één keer, in Ravels twee keer. Ook het aantal toegekende licenties steeg doorheen het project. De gemiddelde afschotrealisatie lag doorheen het project steeds boven de $70 \%$ en was in de meeste jaren hoger dan de gemiddelde afschotrealisatie in de rest van Vlaanderen, de provincie Antwerpen en de omliggende WBE's.

\subsection{JACHTIINSPANNIN GEN, EFFICIËNTIE EN SELECTIVITEIT}

\subsubsection{Projectgebied}

Gedurende het project hielden de licentiehouders gegevens bij in jachtdagboekjes. Bij elke aanzit vulden ze het start- en einduur van de aanzit in, de gebruikte hoogzit, de gedane waarnemingen, het begin- en einduur van deze waarnemingen en de leeftijd en het geslacht van de waargenomen dieren. Indien er geschoten werd, werd ook het labelnummer genoteerd. Het gebruik van de jachtdagboekjes op deze manier laat toe om zicht te krijgen op de geleverde inspanningen, de jachtselectiviteit en de jachtefficiëntie.

Figuur 5 geeft een eerste indicatie van de geleverde jachtinspanning: het aantal aanzitten in de winter is elk jaar hoger dan in de zomer. Bovendien zijn er in Ravels een hoger aantal aanzitten dan in Arendonk. Dit laatste is een logisch gevolg van het groter aantal licenties verdeeld in Ravels (Tabel 2). Het aantal en aandeel van gemeenschappelijke aanzitten is hoger in de winter dan in de zomer. Het toegekende bokkenafschot (zomer) werd meestal reeds binnen de periode van individuele aanzitten behaald, waardoor geen gemeenschappelijke aanzitten georganiseerd werden. 


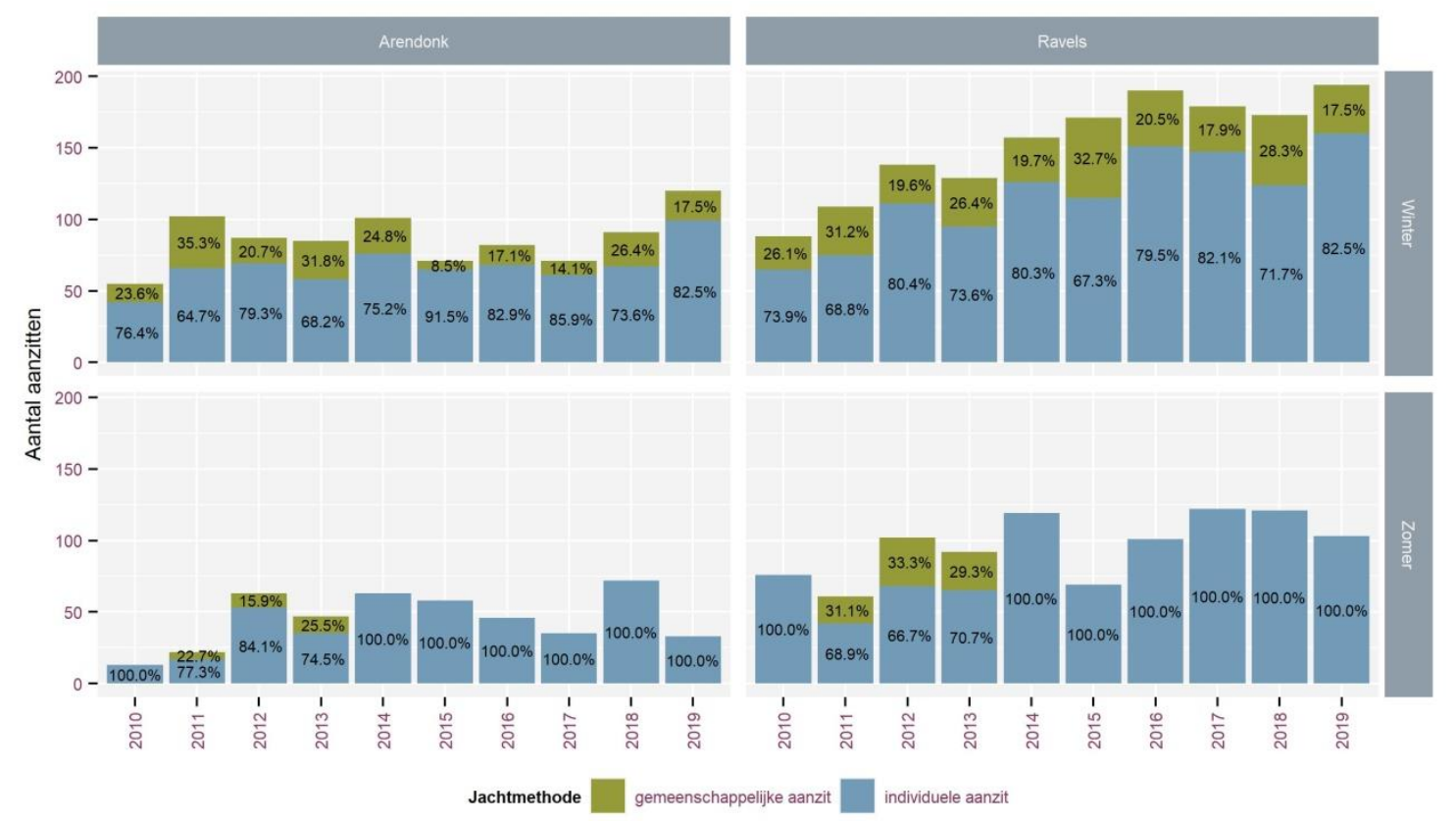

Figuur 5: Het aantal aanzitten in Arendonk en Ravels per jaar en per seizoen verdeeld over het aantal individuele en gemeenschappelijke aanzitten, samen met de procentuele verdeling over beide jachtmethodes

Figuur 6 geeft het aantal waarnemingen dat in de jachtdagboekjes werd geregistreerd weer, opgedeeld volgens waarnemingen met- en zonder schot. Als een maat voor selectiviteit in het afschot kan de verhouding tussen het aantal keren dat reeën in een bepaalde klasse (bok, geit, kits) waargenomen zijn en het percentage van die keren dat er geschoten werd, gehanteerd worden. De redenering hierachter is dat bij een minder selectief afschot (onder tijdsdruk of uit vrees dat anderen het quota zullen vervullen) er relatief sneller en vaker geschoten zal worden. Dit resulteert dan in een hoger percentage van de waarnemingen met een schot. In de jachtdagboekjes kon als reeklasse ook 'onbepaald' aangeduid worden als de jager geen onderscheid kon maken. Voor onderstaande grafiek werden alleen die waarnemingen weerhouden waarin de reeën duidelijk als bok, geit of kits geïdentificeerd en genoteerd werden. 


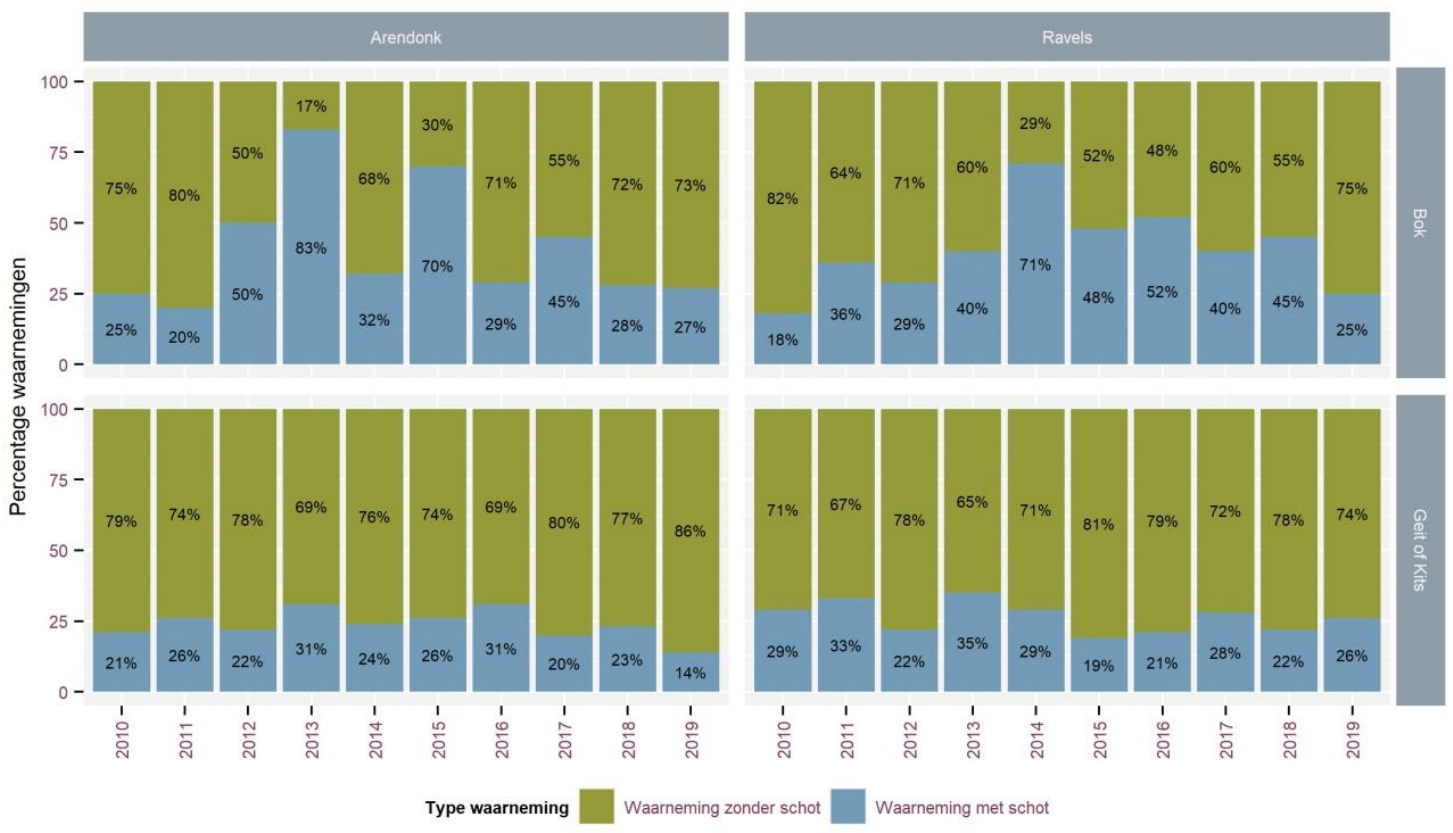

Figuur 6: Het aantal waarnemingen van bokken, geiten en kitsen in Arendonk en Ravels doorheen de jaren. Er wordt een opdeling gemaakt naar waarnemingen met (blauw) en zonder schot (groen). De percentages geven het aandeel waarnemingen met en zonder schot aan

Voor het inschatten van de jachtefficiëntie kunnen het aantal uren aanzit per geschoten dier (Figuur 7a) en het aantal geschoten dieren per aangezeten uur (Figuur 7b) een beeld geven. Ten opzicht van het startjaar van het project lijkt er een lichte stijging in het gemiddeld aantal uren nodig per geschoten dier en omgekeerd een daling in het gemiddeld aantal reeën geschoten per aangezeten uur. De steekproef-eenheid is hier telkens een licentiehouder in een bepaald seizoen, m.a.w. per licentiehouder werd afzonderlijk voor geit/kits en voor de bokkenjacht het aantal uren aanzit per geschoten dier berekend (of het aantal geschoten reeën per aangezeten uur) waarbij dan telkens per gebied en per jaar het gemiddelde en het 95\%-betrouwbaarheidsinterval berekend werd over alle licentiehouders.

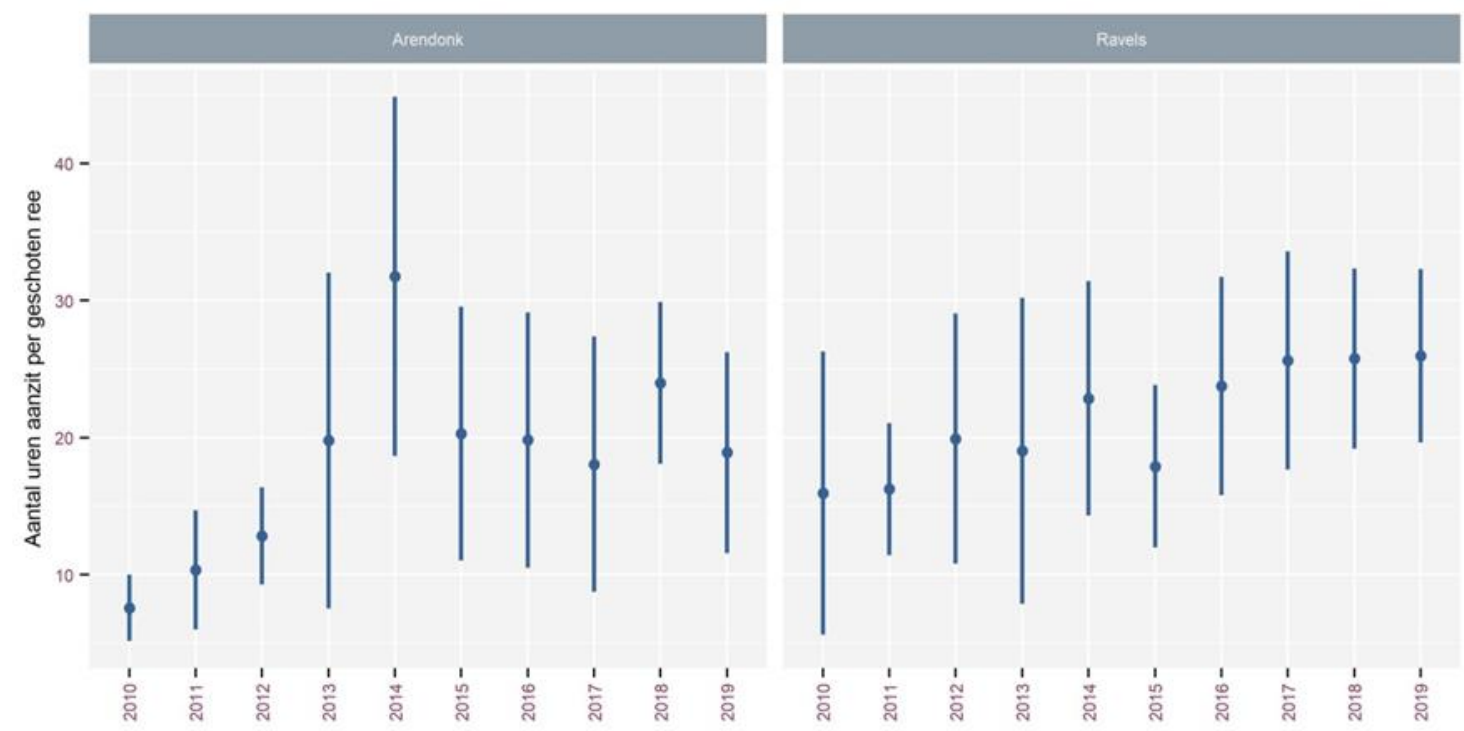




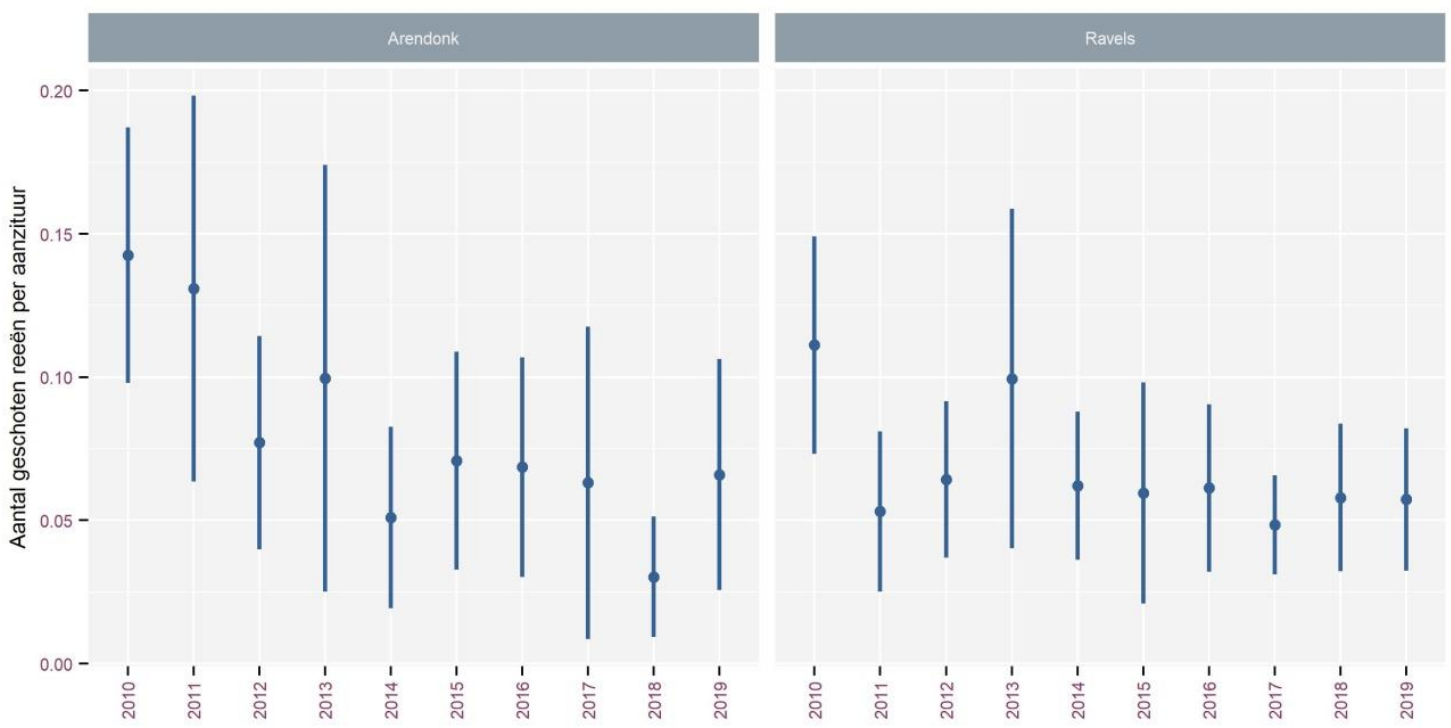

Figuur 7: Het gemiddeld aantal uren aanzit per geschoten ree (a) en het gemiddeld aantal geschoten reeën per aangezeten uur (b) als maat voor de jachtefficiëntie doorheen de jaren in Arendonk en Ravels. Hierbij duiden de punten het gemiddelde aan en de lijnen de betrouwbaarheidsintervallen over alle licentiehouders en per jaar en per gebied

Een andere maat voor jachtefficiëntie bestaat erin om de snelheid waarmee het afschot verwezenlijkt wordt te analyseren. Dit kan aan de hand van het cumulatief afschot (Figuur 8). Hoe sneller het totale afschot wordt gehaald (100\% afschot), hoe steiler deze cumulatieve curve is. Vlakke stukken in deze grafiek wijzen op jachtdagen zonder bijkomend afschot. In de zomer lijkt deze curve doorheen het project steiler te zijn dan in de winterperiode.

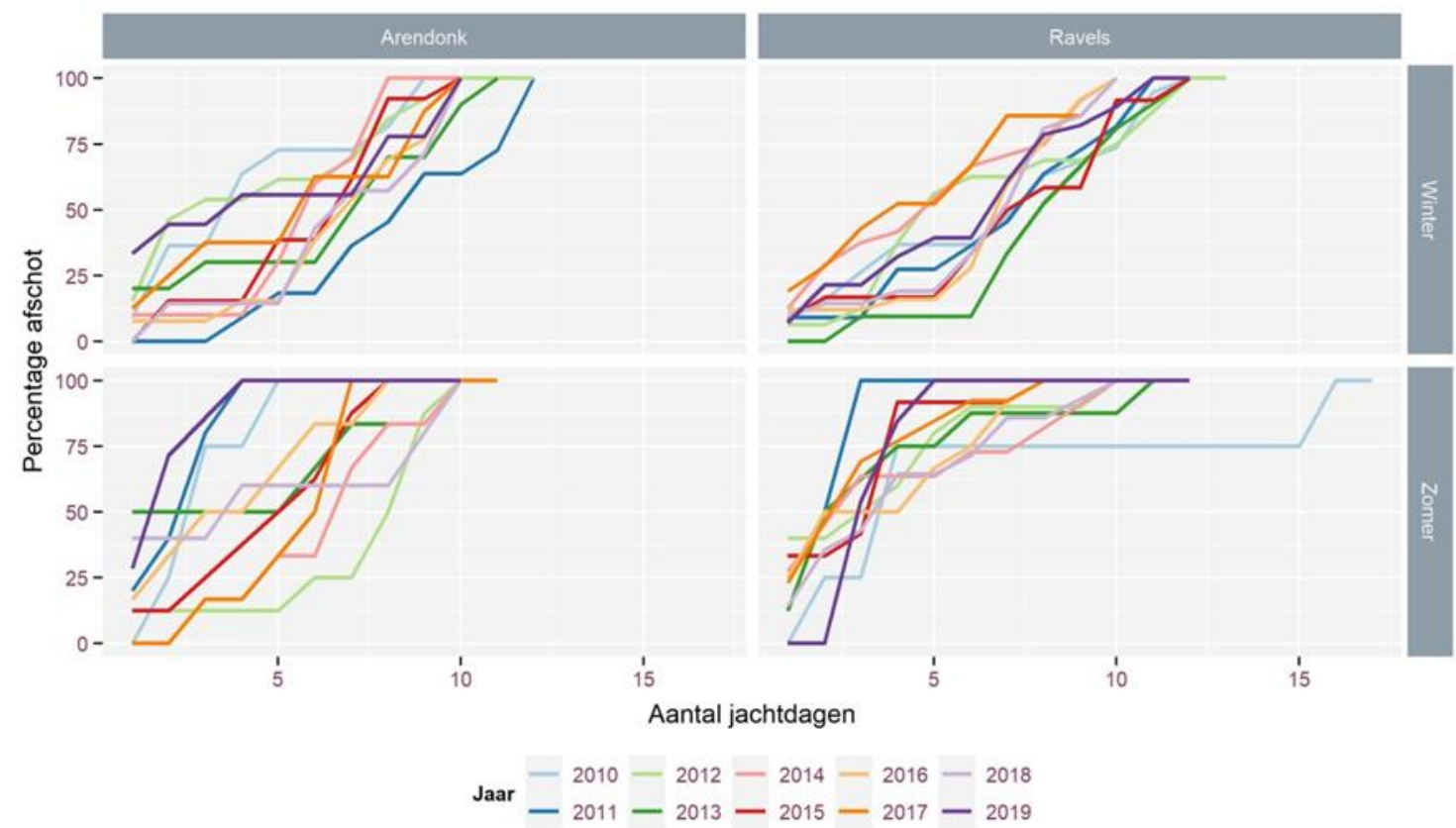

Figuur 8: Verloop van het afschot per jachtperiode doorheen de jaren weergegeven als het percentage behaald afschot per jachtdag opgedeeld in de winter-en zomerperiode 


\subsubsection{Vergelijking met onafhankelijke jagers}

Om een beeld te krijgen of jachtinspanning en jachtefficiëntie binnen licentiejacht vergelijkbaar is met jacht buiten het licentiejachtproject, werden sinds 2011 ook jachtdagboekjes ingevuld door onafhankelijke jagers ( 57 verschillende personen, zie Tabel 4 voor de verdeling van het aantal jachtdagboekjes over de jaren en seizoenen). Dit gebeurde in Meerdaal, Molenbeersel, Overpelt, Zoersel, As, Tielt-Winge, Balen, Dessel, Arendonk, Holsbeek en Diepenbeek.

Tabel 4: Overzicht van het aantal onafhankelijke jagers per jaar en per seizoen

\begin{tabular}{llll}
\hline Jaar & Winter & Zomer & Totaal \\
\hline 2011 & 27 & 18 & 45 \\
2012 & 17 & 12 & 29 \\
2013 & 12 & 8 & 20 \\
2014 & 4 & 3 & 7 \\
2015 & 2 & 2 & 4 \\
2016 & 2 & 2 & 4 \\
2017 & 3 & 2 & 5 \\
2018 & 10 & 9 & 19 \\
2019 & 7 & 12 & 19 \\
\hline
\end{tabular}

De verzamelde gegevens kunnen bijgevolg op een gestandaardiseerde wijze vergeleken worden met de gegevens van de licentiejacht. Net zoals bij de vorige vergelijkingen worden Arendonk en Ravels hier als één gebied beschouwd.

Een belangrijk aandachtspunt is de grote variatie in het aantal onafhankelijke jagers en het beperkt aantal ervan in bepaalde jaren (bijlage 2). De verzamelde data van buiten het proefgebied kunnen daarom niet als een representatieve steekproef voor Vlaanderen beschouwd worden.

Ook voor de onafhankelijke jagers kan de verhouding tussen het totaal aantal waarnemingen en het aantal waarnemingen waarbij geschoten wordt als maat voor selectiviteit of snelheid waarmee men schiet gehanteerd worden. Voor de vergelijking tussen de licentiejachthouders en de onafhankelijke jagers berekenden we deze maat per jager per seizoen per jaar. Er wordt in de onderstaande analyse (Figuur 9) echter geen opdeling gemaakt tussen winter (geit en kits) en zomer (bok). De middelste waarde (mediaan) over de volledige duur van het proefproject verschilt tussen beide groepen (Wilcoxon test, $p$-waarde $<0,05$ ) en situeert zich rond de $32 \%$ voor de licentiehouders en $20 \%$ bij onafhankelijke jagers. Met andere woorden, bij de licentiejachthouders blijkt er gemiddeld ongeveer bij 1 op de 3 keren dat reeën worden waargenomen effectief geschoten te worden, terwijl dit bij de onafhankelijke jagers ongeveer 1 op de 5 keren is. 


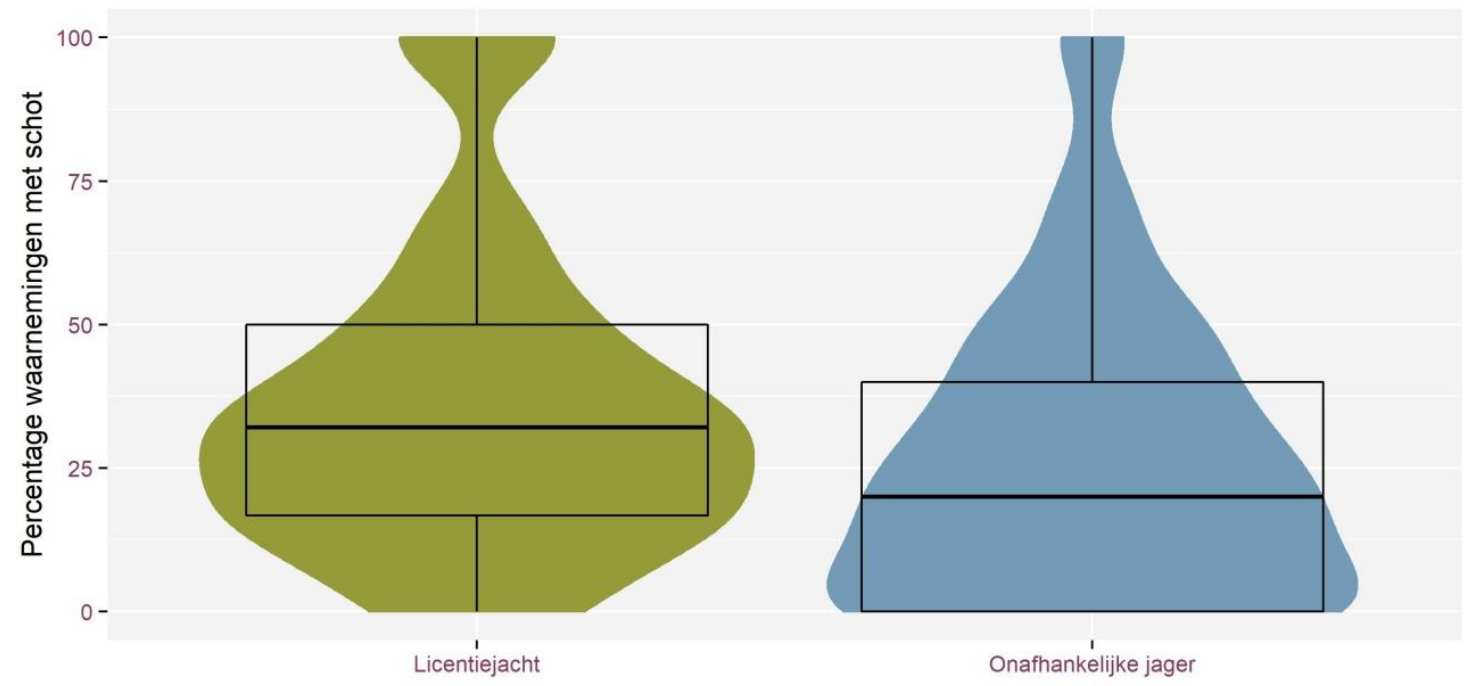

Figuur 9: Het percentage waarnemingen met schot binnen de licentiejacht in vergelijking met de onafhankelijke jagers. In zwart wordt een boxplot weergeven, in kleur een violinplot die een weergave is van de densiteitsverdeling van het aantal jagers per seizoen per jaar met een bepaald percentage waarnemingen met schot

Om de vergelijking te maken voor het aantal uren aanzit per geschoten ree, kunnen enkel die jagers die minstens 1 ree in een seizoen schoten, meegenomen worden voor de volgende analyse (delen door nul is immers niet mogelijk). De mediaan voor beide groepen blijkt vrij gelijk te liggen (16 uur bij licentiejacht, 15 uur bij onafhankelijke jagers, Figuur 10a) (geen significant verschil, Wilcoxon test, $p$-waarde $>0,05$ ) en ook het maximum is heel gelijkaardig (rond 60 uren aanzit voor een reeafschot). Wel is er te zien dat het gewicht van de violinplot iets breder en lager ligt voor de onafhankelijke jagers, wat erop wijst dat bepaalde onafhankelijke jagers slechts een heel korte periode per geschoten ree nodig hebben. Om omgekeerd het aantal geschoten reeën per aanzituur te vergelijken, kunnen alle gegevens gebruikt worden. Ook uit deze data blijkt dat bepaalde onafhankelijke jagers gemiddeld op een zeer korte tijd veel reeën schieten (uitschieters in Figuur 10b). Hoewel het aantal geschoten reeën per aanzituur iets hoger lijkt te liggen voor de licentiehouders dan voor de onafhankelijke jagers, is dit verschil niet significant (Wilcoxon test, $p$-waarde $>0,05$ ). Wanneer de mediane waarde van 0,05 geschoten reeën per aanzituur bij licentiehouders en 0,03 geschoten reeën per aanzituur bij onafhankelijke jagers omgerekend wordt naar aantal uren per geschoten ree, komt dit neer op respectievelijk 20 en 33 uren per geschoten ree. 


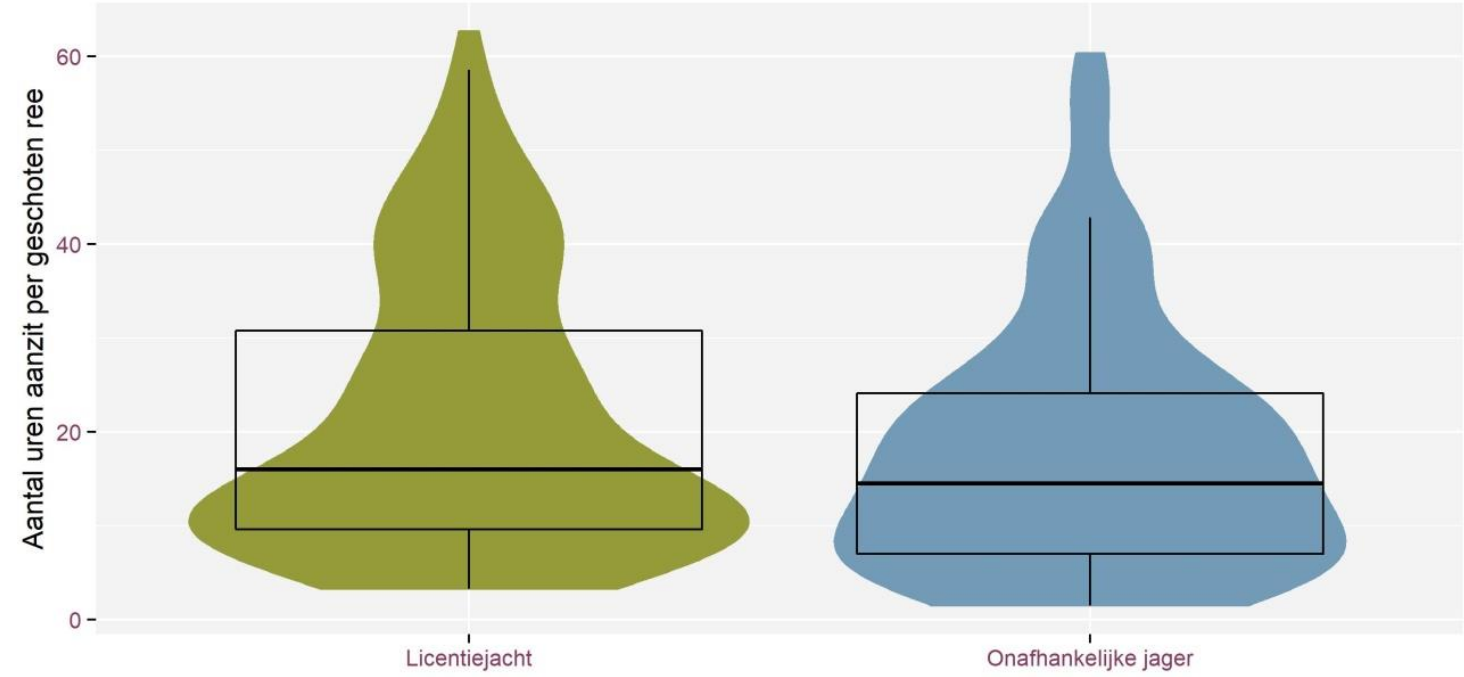

b

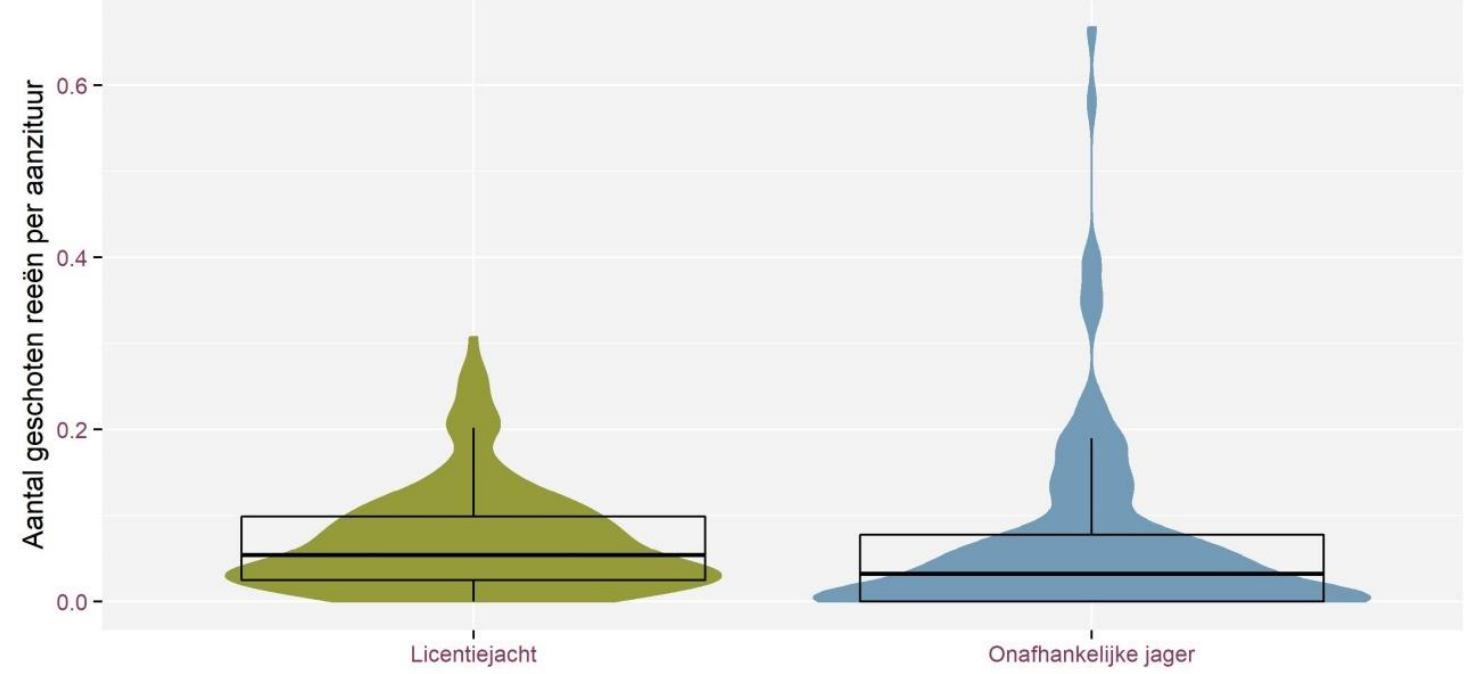

Figuur 10: Vergelijking van het aantal uren aanzit per geschoten ree en het aantal geschoten reeën per aangezeten uur tussen de licentiehouders en onafhankelijke jagers. Bij het aantal uren aanzit per geschoten ree worden enkel jagers die minstens 1 ree geschoten hebben weerhouden, bij het aantal geschoten reeën per aangezeten uur zitten alle jagers bevat (ook degenen die geen reeën hebben geschoten in een bepaald seizoen). In zwart wordt een boxplot weergeven, in kleur een violinplot die een weergave is van de densiteitsverdeling van het aantal jagers per seizoen per jaar met een bepaald aantal aanzituren per geschoten ree/ aantal geschoten reeën per aanzituur

\subsubsection{Conclusie van jachtefficiëntie en selectiviteit}

In alle jaren van het project werden in de wintermaanden bijkomend gemeenschappelijke aanzitten georganiseerd om het afschot van geiten en kitsen te verwezenlijken. De toename van het aantal licenties in Ravels leidde in de winter duidelijk tot een toename in het aantal aanzitten, in Arendonk was dit minder het geval. In de zomermaanden waren er vanaf 2014 geen gemeenschappelijke aanzitten meer. 
Aan de hand van de jachtdagboekjes werd het percentage van de reewaarnemingen waarin ook effectief geschoten werd en het aantal uren per geschoten ree/aantal reeën per uur aanzit tussen het proefproject en een groep onafhankelijke jagers vergeleken. Het percentage waarnemingen met schot lag bij de licentiehouders $(1$ schot per 3 waarnemingen) significant hoger dan bij de onafhankelijke jagers (1 schot per 5 waarnemingen). De selectiviteit lijkt bij de onafhankelijke jagers dus iets hoger te liggen.

Wat jachtefficiëntie betreft, is er geen significant verschil tussen beide groepen. In het licentiejachtproject werd niet significant efficiënter gejaagd(minder uren aanzit per geschoten ree), maar de jachtinspanning was meer geconcentreerd in de tijd.

Een belangrijke bemerking bij deze vergelijking is dat het aantal onafhankelijke jagers waarover we data beschikten, beperkt was en sterk fluctueerde tussen de jaren. De verzamelde data van buiten het proefgebied kunnen daarom zeker niet als een representatieve steekproef voor Vlaanderen beschouwd worden.

\subsection{EFFECT OP DE REEPOPULATIE}

\subsubsection{Populatietrend}

\subsubsection{Inleiding}

Op dit moment zijn er geen gevalideerde methoden om absolute reedensiteiten (aantal dieren per 100 ha) in het kader van beheer exact te bepalen. Voor een specifiek gebied of voor wetenschappelijk onderzoek laten vangst-markeer-hervangst of distance sampling methoden toe om de detectiekans te berekenen, respectievelijk op basis van het aantal waargenomen gemarkeerde dieren of op basis van de afstanden tot de waargenomen dieren. Beide methoden laten ook toe dichtheden of aantallen te berekenen. Een overzicht van mogelijke methoden die gekend waren in 2008 is terug te vinden Casaer and Malengreaux (2008). De kilometertelling uitgevoerd vanuit de wagen is niet toegepast in het proefproject omdat de methode op dat moment nog niet gevalideerd was. Ondertussen is dit wel het geval en blijkt deze methode een winst in tijd en personeelskost met zich mee kan brengen (Pellerin et al., 2017; Pellerin et al., 2014). Ook de methode met cameravallen werd niet gebruikt. Deze technologie was in 2008 - bij de opmaak van het rapport - nog niet tegen aanvaardbare prijs beschikbaar om ingezet te worden als onderzoeksinstrument en kent ook nu nog volop methodologische ontwikkelingen. De keuze bij aanvang van het project was bijgevolg om de kilometerindex op basis van tellingen te voet toe te passen (zie ook (Vercammen et al., 2011)).

\subsubsection{Toepassing van de kilometerindex in het kader van het licentiejachtproject}

Het principe van de kilometerindex bestaat erin om jaarlijks een aantal vaste teltrajecten af te stappen en waarnemingen van reeën te noteren, al dan niet opgedeeld naar bokken, geiten en kitsen.

Door vervolgens het aantal reeën te delen door de afgelegde afstand, bekom je een kilometerindex (het aantal geobserveerde reeën per kilometer traject) van een bepaald parcours (KIp). Na elke telsessie wordt eerst de kilometerindex per traject berekend waarbij $n$ staat voor het nummer van een bepaald parcours en $m$ voor de telling.

$$
K I p_{n m}=\frac{\text { Totaal aantal waargenomen reeën op traject } \mathrm{i} \text { bij telling } \mathrm{x}}{\text { Totaal aantal kilometers van traject } \mathrm{i}}
$$


Per serie of reeks bestaande uit alle trajecten samen van een bepaalde datum, kan de kilometer-index voor die telling (of reeks) berekend worden. Deze is het gemiddelde over alle parcours die op die dag geteld worden.

$$
K I r_{m}=\frac{\text { Som van KIp's van de uitgevoerd e trajecten }}{\text { aantal uitgevoerd e trajecten }(\mathrm{n})}
$$

Om uit de index statistisch verantwoorde conclusies te trekken, zijn jaarlijks minstens 3 à 4 telsessies nodig. Die worden liefst in een zo kort mogelijke periode (bv. 1 maand) uitgevoerd. Per telsessie worden alle trajecten afgestapt. Dat gebeurt bij voorkeur simultaan op dezelfde ochtenden of avonden. Op basis hiervan wordt een jaarlijks gemiddelde bekomen.

$$
\text { KIjaar }=\frac{\text { Som van alle KIr's }}{\text { totaal aantal uitgevoerd e reeksen (tellingen })(\mathrm{m})}
$$

Op dit gemiddelde kan een betrouwbaarheidsinterval worden berekend. Deze manier van werken laat toe om op een statistisch verantwoorde manier de gemiddelden over een tijdsperiode te vergelijken.

Het Office Français de la Biodiversité (het vroegere Office National de la Chasse et de la Faune Sauvage of ONCFS) die deze werkwijze op punt stelde en valideerde, geeft als richtlijn ongeveer $3 \mathrm{~km}$ traject per 100 ha te tellen bosgebied en trajecten tussen 5 en $7 \mathrm{~km}$ lang. Om een traject af te stappen rekenen ze 2 tot 3 uur5. In Vlaanderen hanteren we eenzelfde densiteit, maar kortere trajecten $(4,5$ tot $5 \mathrm{~km})$ zodat het traject in ongeveer 1.301 .45 uur gewandeld kan worden.

Voor dit project tekenden we acht trajecten uit: vijf in Ravels en drie in Arendonk (Figuur 11). De acht teltrajecten hebben samen een lengte van $35,2 \mathrm{~km}$ voor een totale oppervlakte van \pm $1340 \mathrm{ha}$. De dichtheid bedraagt daarmee 2,6 km per $100 \mathrm{ha}$, net iets minder dan het streefdoel van $3 \mathrm{~km}$ per $100 \mathrm{ha}$. De trajecten zijn zodanig uitgestippeld dat een telling in het in het ene traject zo weinig mogelijk verstoring veroorzaakt in een ander traject.

Per jaar vonden vier tellingen plaats: twee ochtendtellingen (vanaf zonsopgang) en twee avondtellingen (anderhalf uur voor zonsondergang). Vrijwilligers, bestaande uit de licentiejagers en andere geïnteresseerden, voerden de tellingen uit onder coördinatie van een personeelslid van het INBO. 


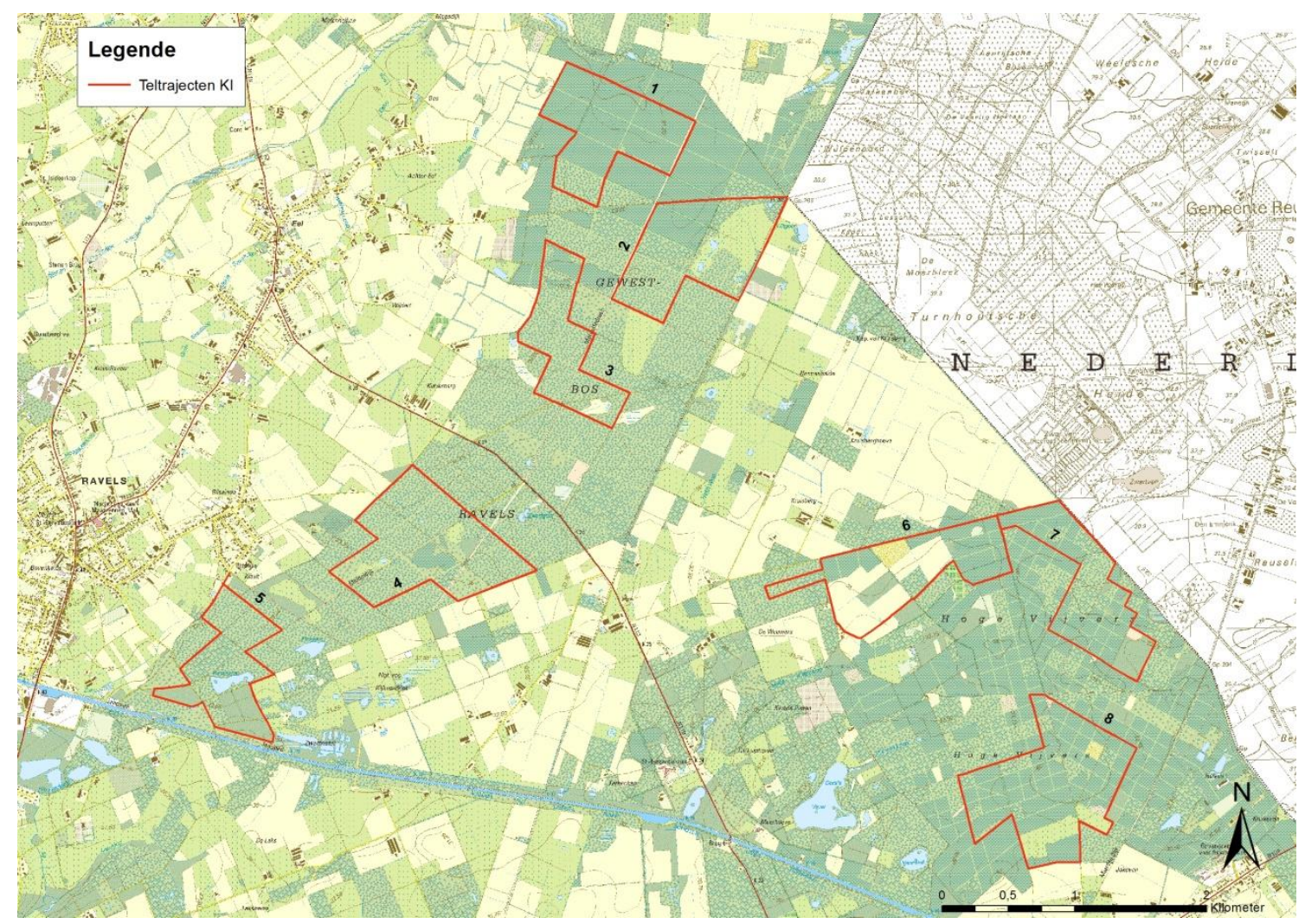

Figuur 11: Overzicht van de teltrajecten in Ravels en Arendonk

\subsubsection{Resultaten van de kilometertellingen in Ravels en Arendonk}

Met uitzondering van één keer in 2015 werden steeds alle trajecten geteld. De eenvoudigste manier om naar de verzamelde data te kijken, is om het aantal getelde trajecten waarop reeën waargenomen werden te vergelijken met het totaal aantal getelde trajecten dat jaar (Figuur 12). Voor Ravels zien we tussen 2011 en 2018 een lichte stijging in het aantal getelde trajecten waarbij geen reeën waargenomen werden. 


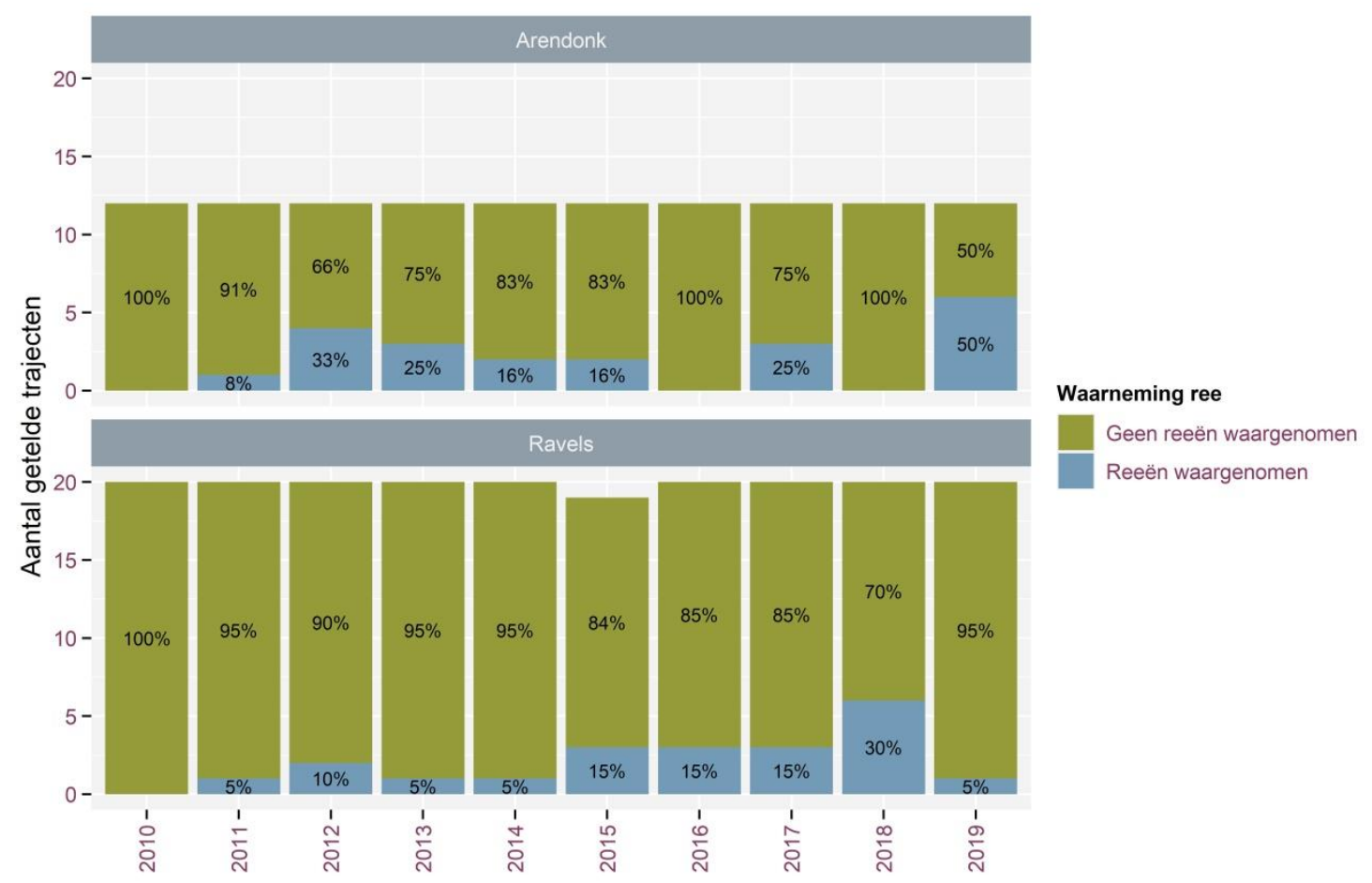

Figuur 12: Aantal getelde trajecten per jaar met aanduiding van deze waar wel (in het blauw) en die waar geen (in het groen) reeën waargenomen werden

De klassieke manier om dergelijke data in functie van reewildbeheer te bekijken5, is om de jaarlijkse gemiddelde KI met het bijhorende betrouwbaarheidsinterval te visualiseren (Figuur 13a). Hieruit blijkt dat in Ravels de geobserveerde aantallen pas duidelijk dalen nadat het gerealiseerd afschot tussen 2011 en 2013 jaarlijks toenam (Figuur 3). Nadat het verhoogd afschot gehandhaafd blijft sinds 2014, blijft ook de populatie op een lager niveau. Voor Arendonk lijkt het erop dat de populatie na het eerste jaar van het project reeds op een lager niveau komt en ook laag blijft. In 2016 en 2018 worden er echter opvallend meer reeën waargenomen. We plaatsen hier wel een kanttekening bij. Hoewel de getelde afstand in verhouding tot de grootte van het bos in Arendonk theoretisch voldoende is, gaat het maar over drie trajecten (Figuur 11). Uit een lineaire regressie blijkt dat de dalende trend over de volledige periode voor Ravels sterker is dan in Arendonk (Figuur 13b). 


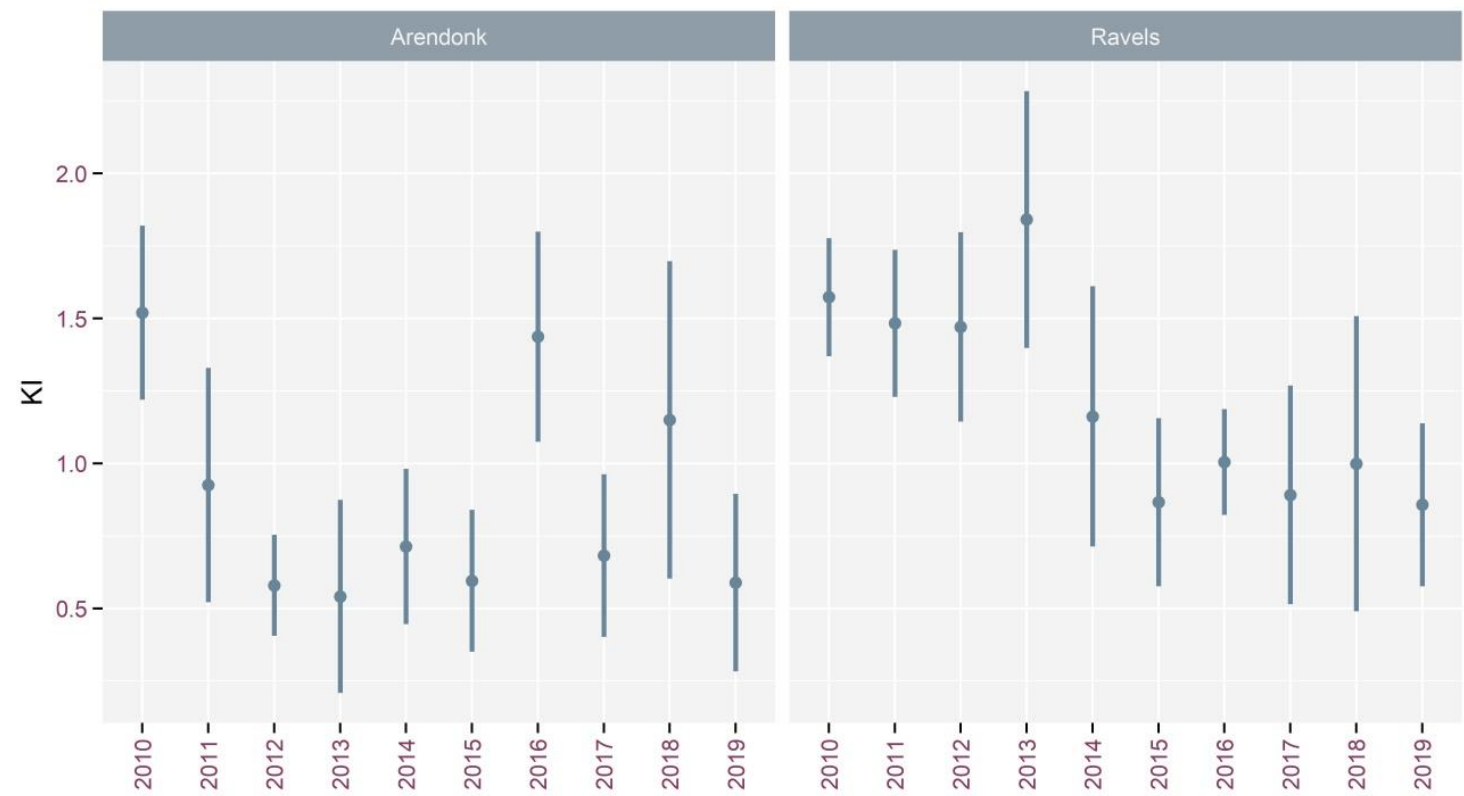

b

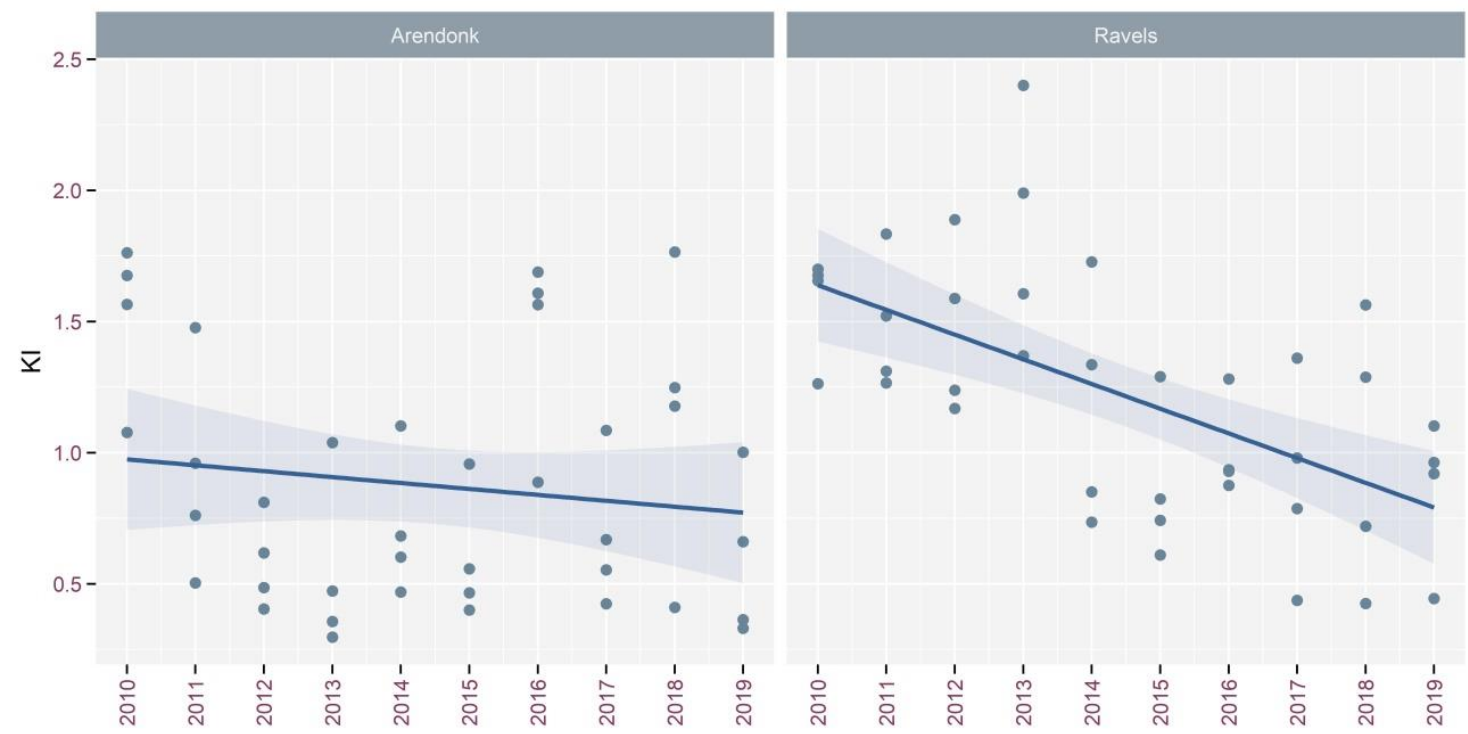

Figuur 13: Resultaten van de kilometertellingen te voet voor Ravels en Arendonk. De bovenste figuur (a) geeft per jaar de gemiddelde kilometerindex (KI) en het betrouwbaarheidsinterval weer, de onderste figuur (b) de kilometerindex voor elk van de vier tellingen en een lineaire regressie met het betrouwbaarheidsinterval op deze regressie

\subsubsection{Waarnemingen gedurende de aanzit}

Het gebruik van jachtdagboekjes geeft ook een zicht op het aantal waarnemingen (in relatie tot de aanzitduur) en het aantal waargenomen dieren tijdens de aanzit. Hoewel deze methode niet gevalideerd werd als indicator voor het opvolgen van populatietrends bij reewild, wordt het hier wel kort besproken. Deze parameter is immers een directe weerspiegeling van de indruk die de jagers krijgen gedurende hun aanzit. 


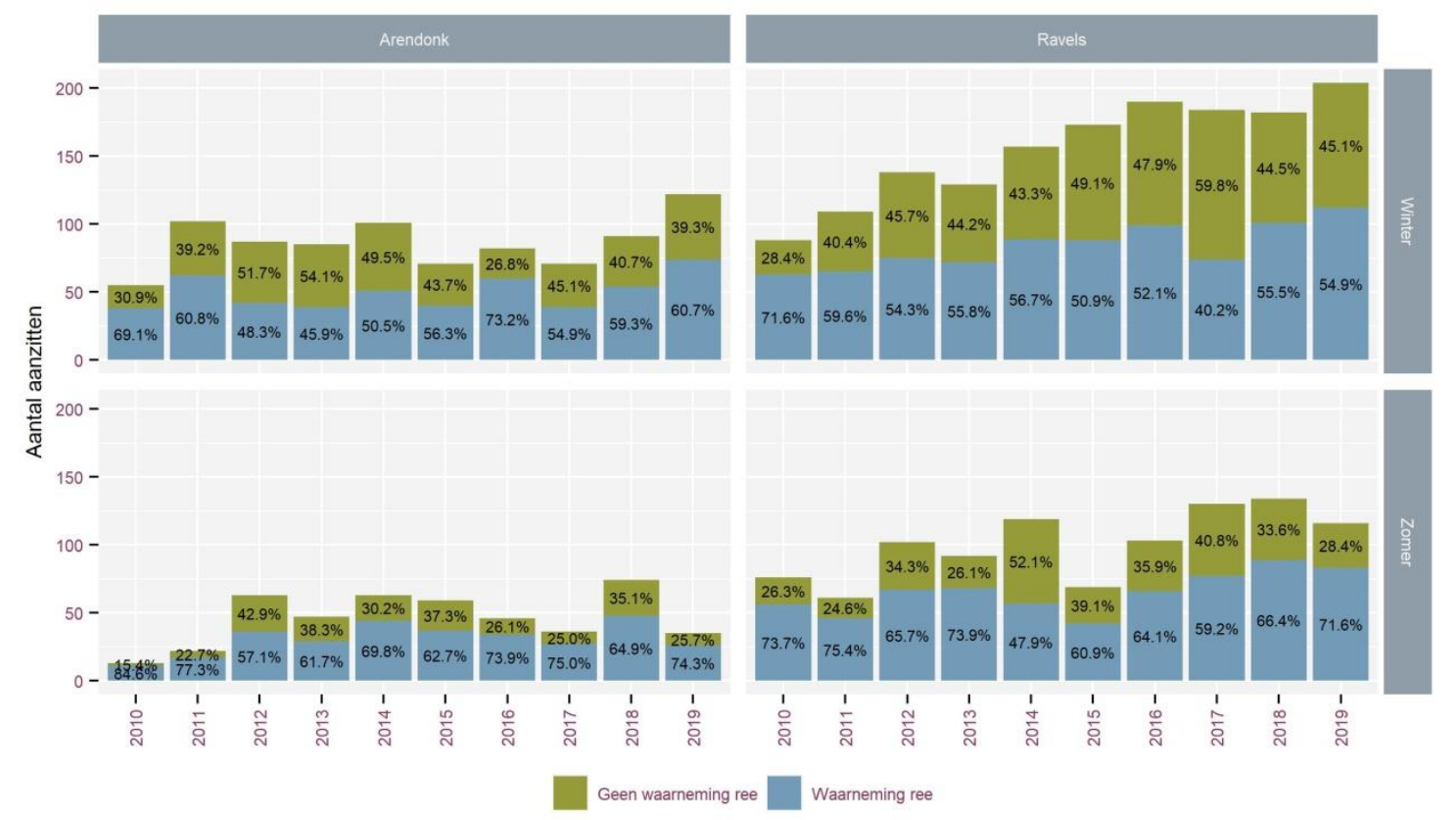

Figuur 14: Verdeling van het aantal aanzitten met of zonder waarnemingen per jaar voor Ravels en Arendonk, opgedeeld naar de zomer en de winter

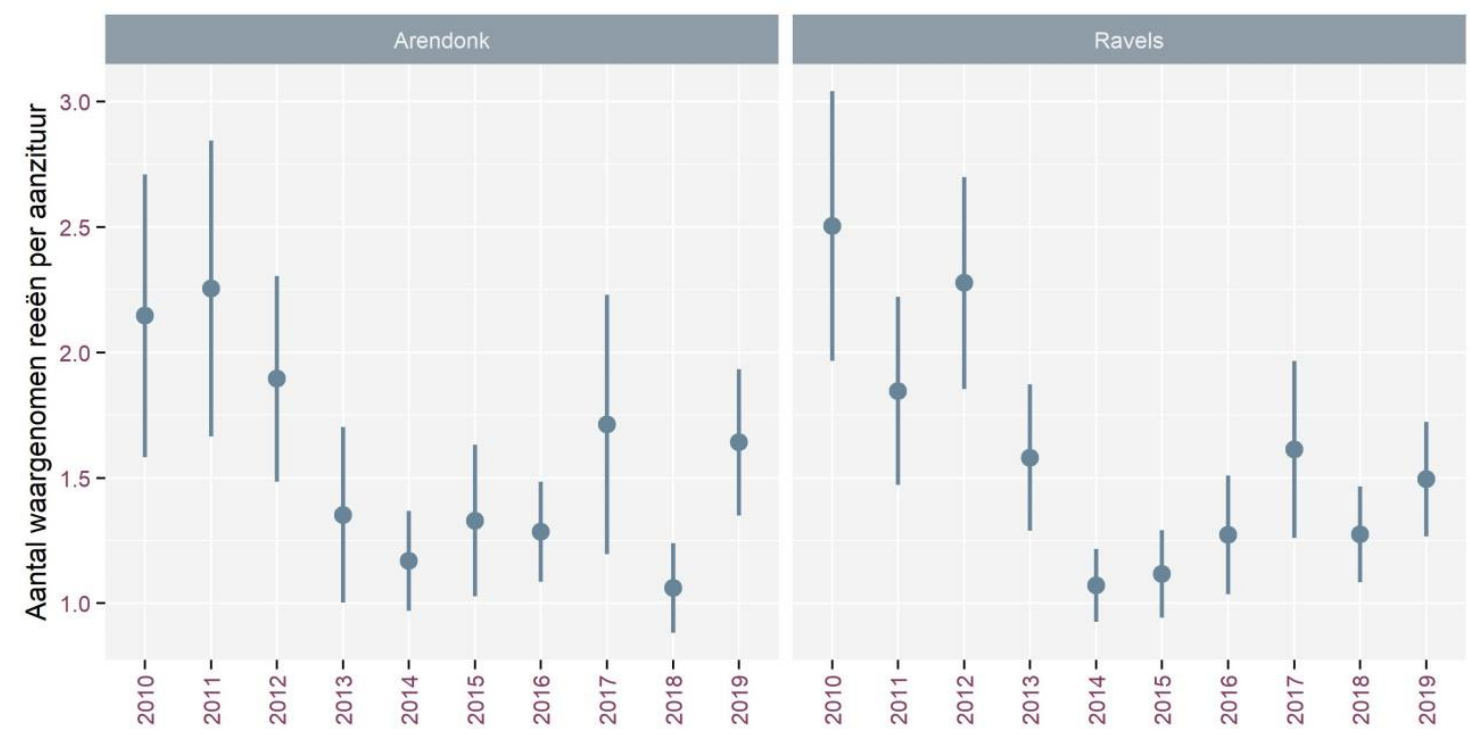

Figuur 15: Aantal waargenomen reeën per uur aanzit per jaar en per deelgebied. Elk punt stelt de gemiddelde waarde voor een bepaald jaar voor, de lijn het betrouwbaarheidsinterval rond deze waarde 


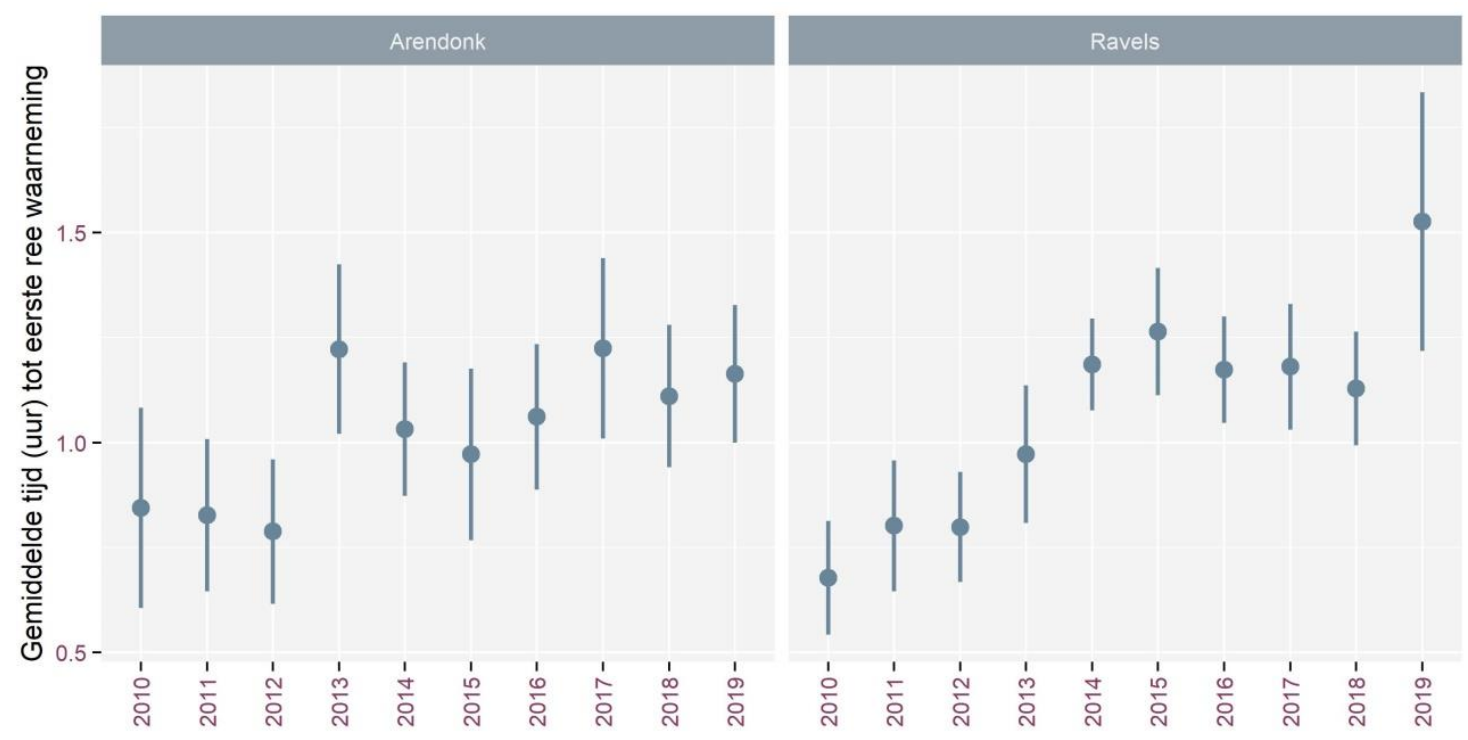

Figuur 16: Tijd tot de eerste waarneming van een ree per jaar en per deelgebied. Elk punt stelt de gemiddelde waarde voor een bepaald jaar voor, de lijn het betrouwbaarheidsinterval rond deze waarde

De daling in het aantal waargenomen reeën per aangezeten uur (Figuur 15) zowel als de langere gemiddeld tijd tot een eerste waarneming (Figuur 16) liggen in lijn met de resultaten van de kilometerindex en wijzen op een daling van de reestand doorheen de duur van het proefproject. In het percentage van de aanzitten waarin reeën waargenomen worden, vinden we deze verandering niet terug (Figuur 14, lineair model $p$-waarde voor jaareffect $>0.1$ ).

\subsubsection{Waarnemingskans}

Een lager aantal waargenomen reeën kan wijzen op een effectief lager aantal reeën, maar ook het gevolg zijn van een verminderde waarnemingskans. Onder waarnemingskans verstaan we 'de waarschijnlijkheid dat een aanwezige ree ook effectief waargenomen wordt'. Een verminderde waarnemingskans kan zowel aan een veranderd gedrag van de reeën te wijten zijn, als aan een verminderde zichtbaarheid in het bos door een toename van dekking (struiken en jonge bomen). Het telprotocol zoals uitgetest door de het OFB/ONCFS brengt dit aspect niet specifiek in rekening.

In een klassiek bos- en wildbeheer is het weinig waarschijnlijk dat over het gehele boscomplex in een bepaalde periode grote veranderingen in waarnemingskans zullen optreden. Ingrepen in de vegetatie of de reepopulatie gebeuren meestal geleidelijk. Grote wijzigingen kunnen bijvoorbeeld wel voorkomen door calamiteiten (windval na storm, bosbrand), grootschalige omvormingsbeheer plaats vindt, of wanneer op korte tijd sterk wordt ingegrepen in de reepopulatie om bosverjonging extra kansen te geven. In dat laatste geval is er niet alleen een lagere reepopulatie, maar kan de ingreep ook resulteren in een schuchter gedrag van de reeën, waardoor de waarnemingskans nog verlaagt.

De problematiek van het mogelijk effect van de vegetatie op de waarnemingskans kwam pas onder de aandacht van de onderzoekers en de stuurgroep naar aanleiding van vragen over de sterke terugval in het aantal waargenomen reeën in het Zoniënwoud (Casaer et al., 2017). Als gevolg hiervan werd pas in 2016 gestart met de nodige metingen voor het evalueren van een mogelijke verminderde waarnemingskans door de verandering in de vegetatie. De evaluatie gebeurde aan de hand van twee methoden. 


\subsection{Meten van de zichtbaarheid}

Om een benaderende uitspraak te kunnen doen over de waarnemingskans, werd de zichtbaarheid in de gebieden opgemeten in 2016 en 2019. Dat gebeurde telkens in de periode van de trajecttellingen. Op elk van de acht telparcours werd om de $500 \mathrm{~m}$, afwisselend links en rechts van de weg, de zichtbaarheid geschat op $12,5 \mathrm{~m}, 25 \mathrm{~m}$ en $50 \mathrm{~m}$. Dit gebeurde met behulp van een $1,70 \mathrm{~m}$ lange meetlat, onderverdeeld in vakken van $10 \mathrm{~cm}$, alternerend geel en oranje van kleur (Figuur 17). Op de drie afstanden werd gekeken in welke mate de vegetatie deze vakken bedekte. Elk van de 17 vakken kreeg een waarde 1 (volledig zichtbaar), 0,5 (deels zichtbaar) of 0 (niet zichtbaar). In totaal werd op 65 locaties op elk van de drie afstanden een meting uitgevoerd. De metingen vonden in beide jaren plaats op dezelfde locaties.

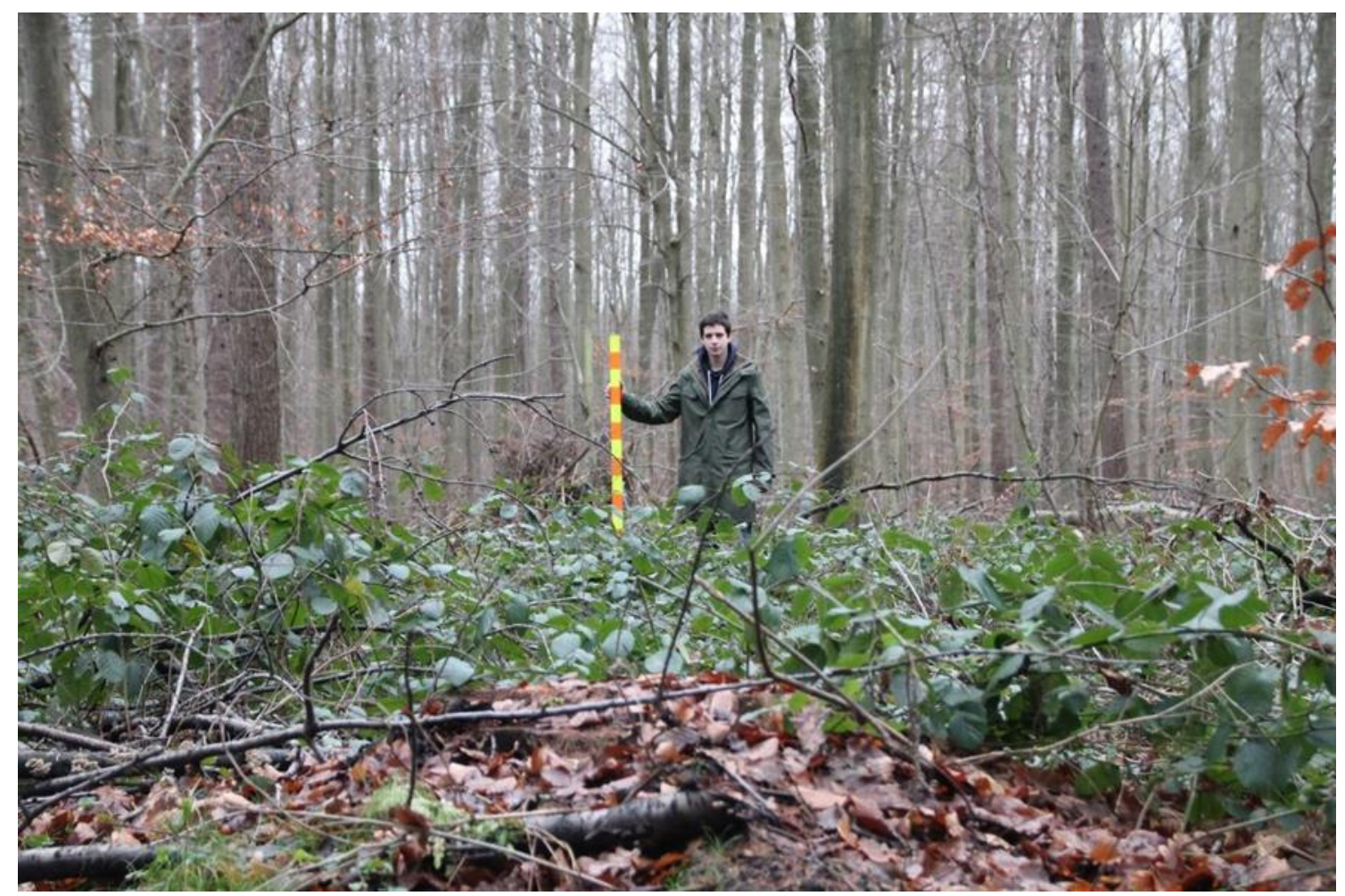

Figuur 17: Gebruik van een baken met gekleurde banden voor het meten van de zichtbaarheid. Foto afkomstig uit het Zoniënwoud (Stanislas Sibille).

De zichtbaarheid werd berekend door voor elk hoogte-interval de zichtbaarheidswaarde te vermenigvuldigen met het aandeel van een ree dat in die hoogteklasse voorkomt. Voor deze berekening maakten we gebruik van het profiel van een staand ree (Casaer, 2003)(Figuur 18). 


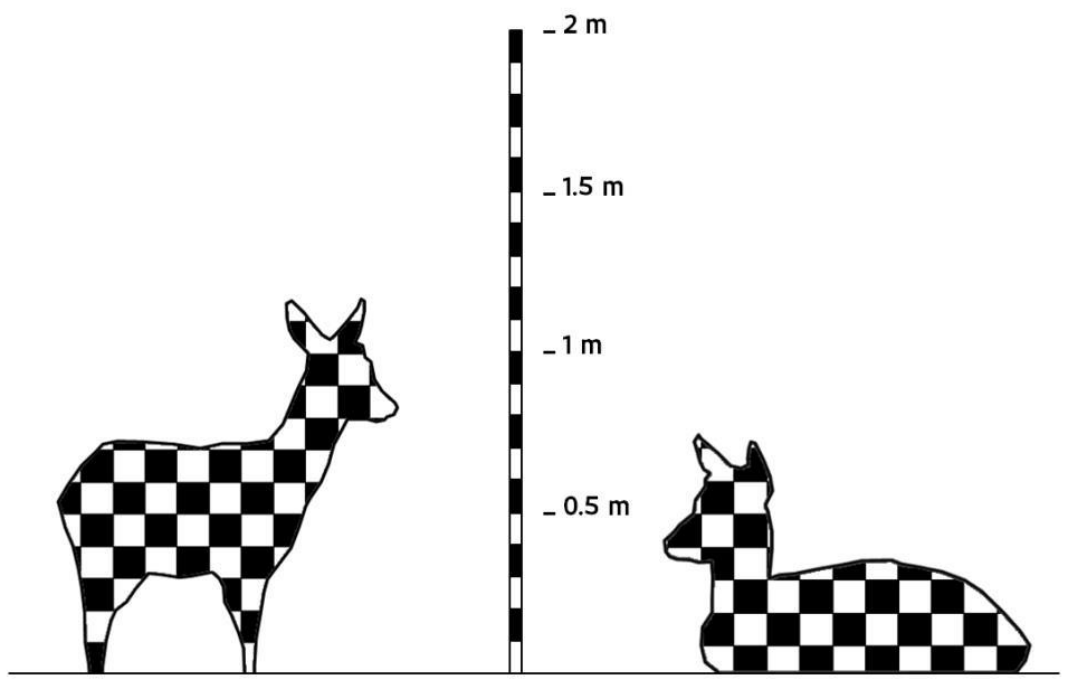

Figuur 18: Verdeling van het oppervlak van een staand (links) en liggend (rechts) ree in elk hoogteinterval . Elk vierkantje stelt een oppervlakte van 10*10 cm voor (naar Casaer (2003))

Uit de resultaten blijkt geen algemene toe- of afname van de zichtbaarheid in Ravels en Arendonk in de periode tussen de twee metingen (Figuur 19).

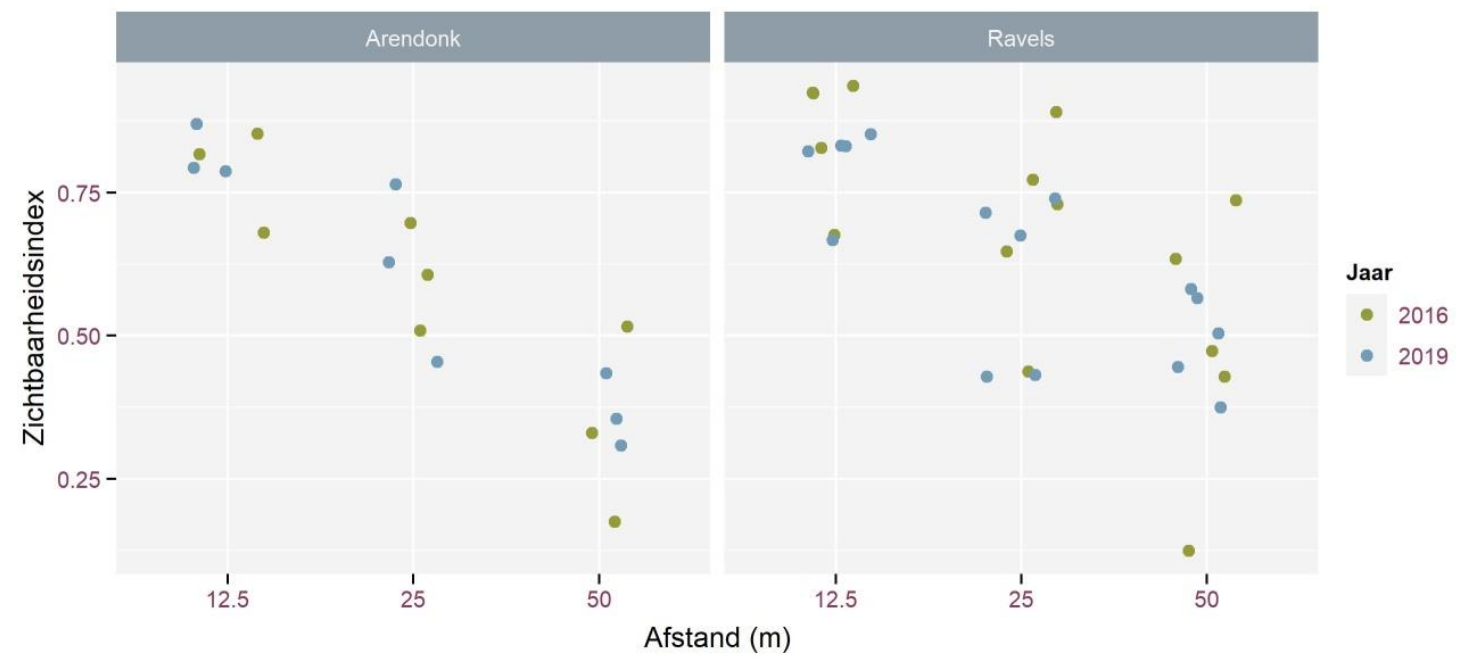

Figuur 19: Vergelijking van de zichtbaarheidsindex per traject in 2016 (groen) en 2019 (blauw) opgedeeld naar gebied en afstand

\subsection{Meten van de waarnemingsafstand}

Een tweede benadering om een zicht te krijgen op mogelijke veranderingen in de waarnemingskans, is om gedurende de tellingen de afstand te meten waarop de reeën waargenomen worden. Bij elke waarneming van één of meerdere reeën meet de waarnemer met een afstandsmeter (Nikon Aculon 6X20) de afstand tussen zichzelf en het dier. Omdat het meestal niet mogelijk is rechtsreeks op het dier te meten, wordt meestal gericht op de boom het dichtst bij de locatie waar de ree waargenomen werd. Wanneer een dier op een dreef of weg staat, wordt naar analogie met de methode van Distance Sampling, de waarde ' 0 ' genoteerd. De zichtbaarheid is hier immers steeds $100 \%$. Vermits we geïnteresseerd zijn in de afstand waarop dieren in het bosbestand gezien kunnen worden als maat voor de zichtbaarheid, namen we de nulwaarden niet mee op in de analyses. Figuur 20 geeft voor

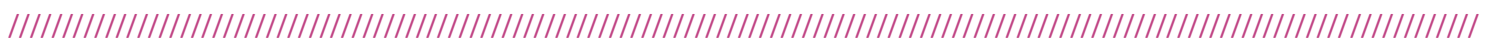


Ravels en Arendonk de verdeling van de afstanden weer per jaar. Tussen 2016 en 2019 blijkt er geen duidelijke afname of toename te zijn in de waarnemingsafstand, noch in Arendonk, noch in Ravels (lineaire regressie, $p$-waarde voor beide gebieden $>0.05$ )

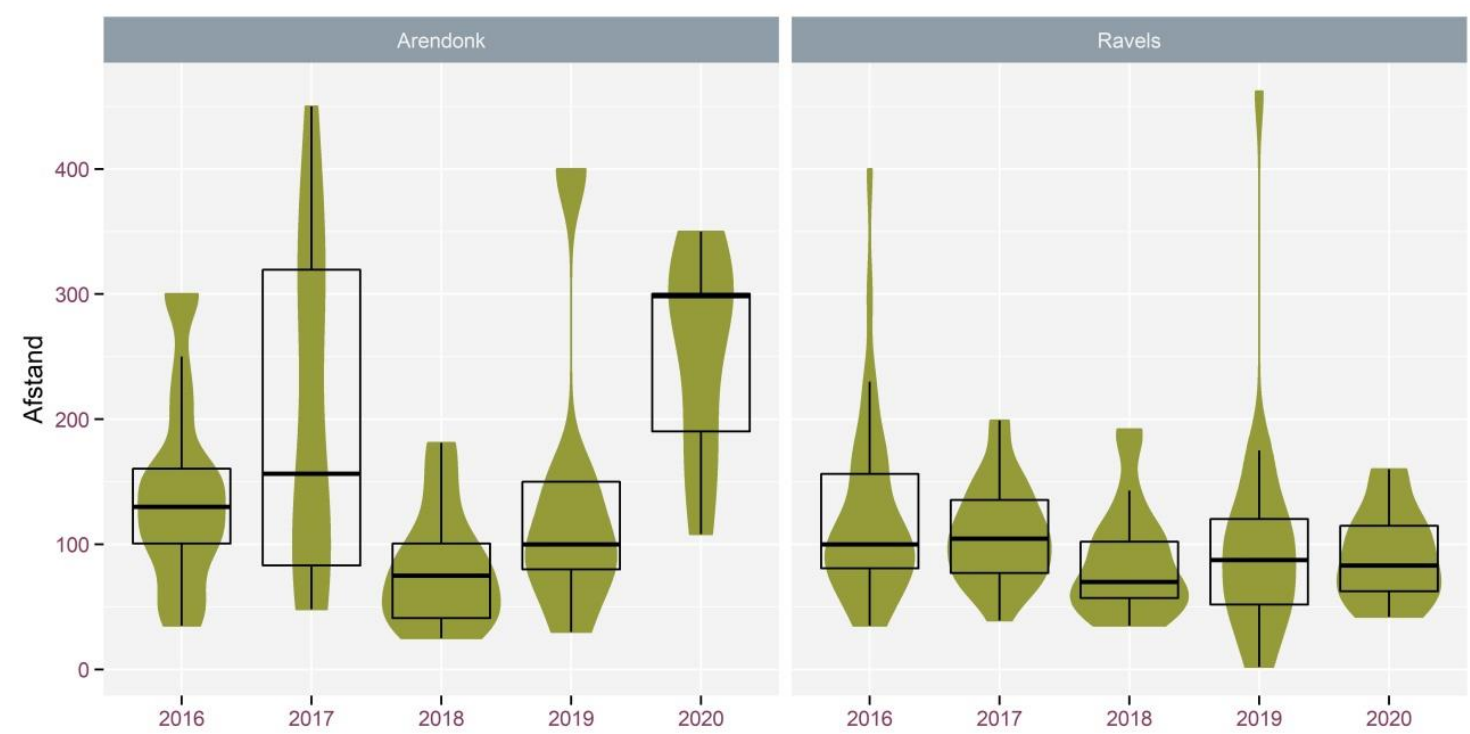

Figuur 20: Verdeling van de waarnemingsafstanden voor Ravels en Arendonk. Nulwaarden werden niet mee opgenomen in de analyse (zie tekst)

\subsubsection{Conclusie populatietrend}

De trajecttellingen, zichtbaarheidsmetingen, afstandsmetingen en de gegevens uit de jachtdagboekjes wijzen allemaal op een daling van de populatie tussen 2010 en 2019, zowel in Arendonk als in Ravels. De beoogde daling van de reepopulatie is dus bereikt.

\subsubsection{Conditieparameters}

\subsubsection{Inleiding}

Naast de kilometerindex kunnen ook een aantal indicatoren opgemeten bij geschoten reeën, mogelijke veranderingen in de verhouding tussen de draagkracht van het gebied en het aantal reeën aantonen. Dergelijke parameters noemen we bio-indicatoren. De basis voor het gebruik van bio-indicatoren zijn de densiteitsafhankelijke mechanismen die bij reewild zorgen voor veranderingen in reproductie en overleving (Blant and Gaillard, 2004; Kjellander, 2000; Morellet et al., 2007). Voor reewild zijn zowel de lengte van de onderkaak als het leeggewicht van de kitsen gevalideerd als bio-indicatoren (Michallet et al., 2015). Hoewel enkel voor edelhert gevalideerd als bio-indicator, worden in Vlaanderen ook het percentage drachtige dieren ouder dan 12 maanden en het aantal embryo's per drachtig dier mee opgevolgd. Deze parameters geven belangrijke informatie over de performantie van de reepopulatie. Naast indicatoren die een beeld geven van de conditie van de reeën, vormen ook de kilometerindex (zie 5.3.1) en het meten van vraat door reeën (zie 5.4) bio-indicatoren die gehanteerd worden om het reewildbeheer mee op te volgen, te evalueren en bij te sturen (Huysentruyt and Casaer, 2012; Michallet et al., 2015; Morellet et al., 2007). 


\subsubsection{Projectgebied}

\subsection{Leeggewicht en onderkaaklengte van de kitsen}

De twee belangrijkste gevalideerde bio-indicatoren voor het opvolgen van de toestand van een reepopulatie zijn de leeggewichten en onderkaaklengte van de kitsen. Wanneer een populatie toeneemt terwijl de draagkracht van het gebied gelijk blijft, worden de kitsen lichter en hun onderkaken korter. Omgekeerd zullen bij een toename van de draagkracht van het gebied of een afname van de populatie, beide parameters stijgen. Zowel het voedselaanbod als de stress die reeën in een gebied ervaren, kunnen factoren zijn die mee bepalend en sturend zijn voor deze densiteitsafhankelijke mechanismen.

In tegenstelling tot de suggestie van het Office Nationale des Forêts, hebben we de gemeten onderkaaklengte noch het leeggewicht van de kitsen gecorrigeerd voor de afschotdatum. Om dit te doen zou immers per jaar en per gebied een regressieanalyse tussen de gewichten en de afschotdatum uitgevoerd moeten worden. Omwille van de beperkte dataset kozen we ervoor dit niet te doen. Onderstaande grafieken en conclusies zijn bijgevolg gebaseerd op de ruwe data zoals ze opgemeten werden, waardoor er potentieel ruis op de gegevens zit.

Gedurende het proefproject werden 220 kitsen geschoten, 140 in Ravels en 80 in Arendonk. Van 7 kitsen kon de onderkaak niet gemeten worden, veelal omdat ze afgebroken of beschadigd waren bij het uitsnijden ervan ( 2 in 2016, 1 in 2018 en 4 in 2019). Van alle geschoten kitsen is het leeggewicht gekend.

Zowel de leeggewichten (Figuur 21) als de onderkaaklengte (Figuur 22) vertonen een stijging doorheen de jaren van het project. Deze stijging is voor beide bio-indicatoren meer uitgesproken in Ravels dan in Arendonk. Dat de betrouwbaarheidsintervallen in Ravels kleiner zijn dan in Arendonk, is deels gerelateerd aan het groter aantal gegevens in Ravels dan in Arendonk.

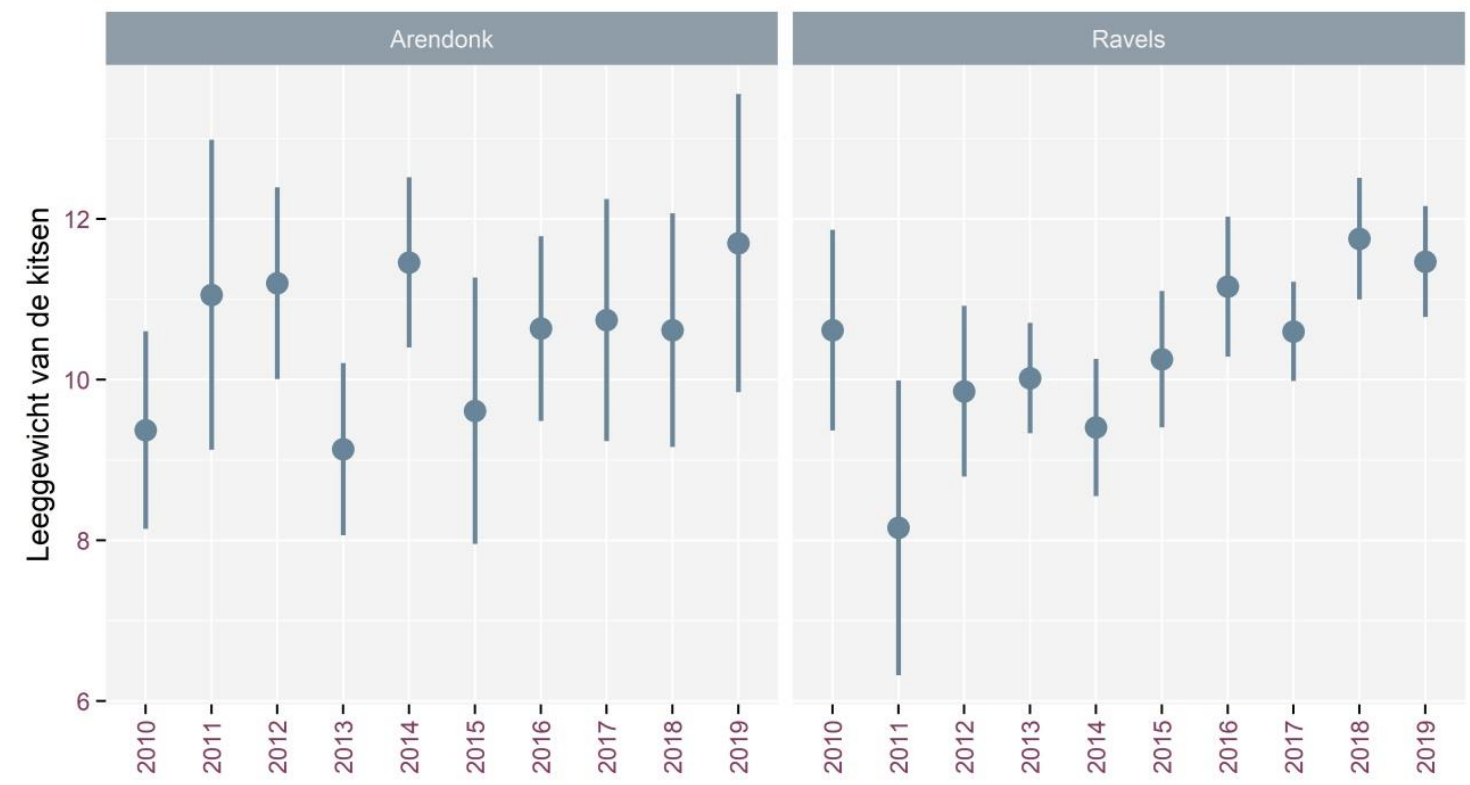

Figuur 21: Evolutie van de leeggewichten van de kitsen per jaar en per deelgebied. Elk punt stelt de gemiddelde waarde voor een bepaald jaar voor, de lijn het betrouwbaarheidsinterval rond deze waarde 


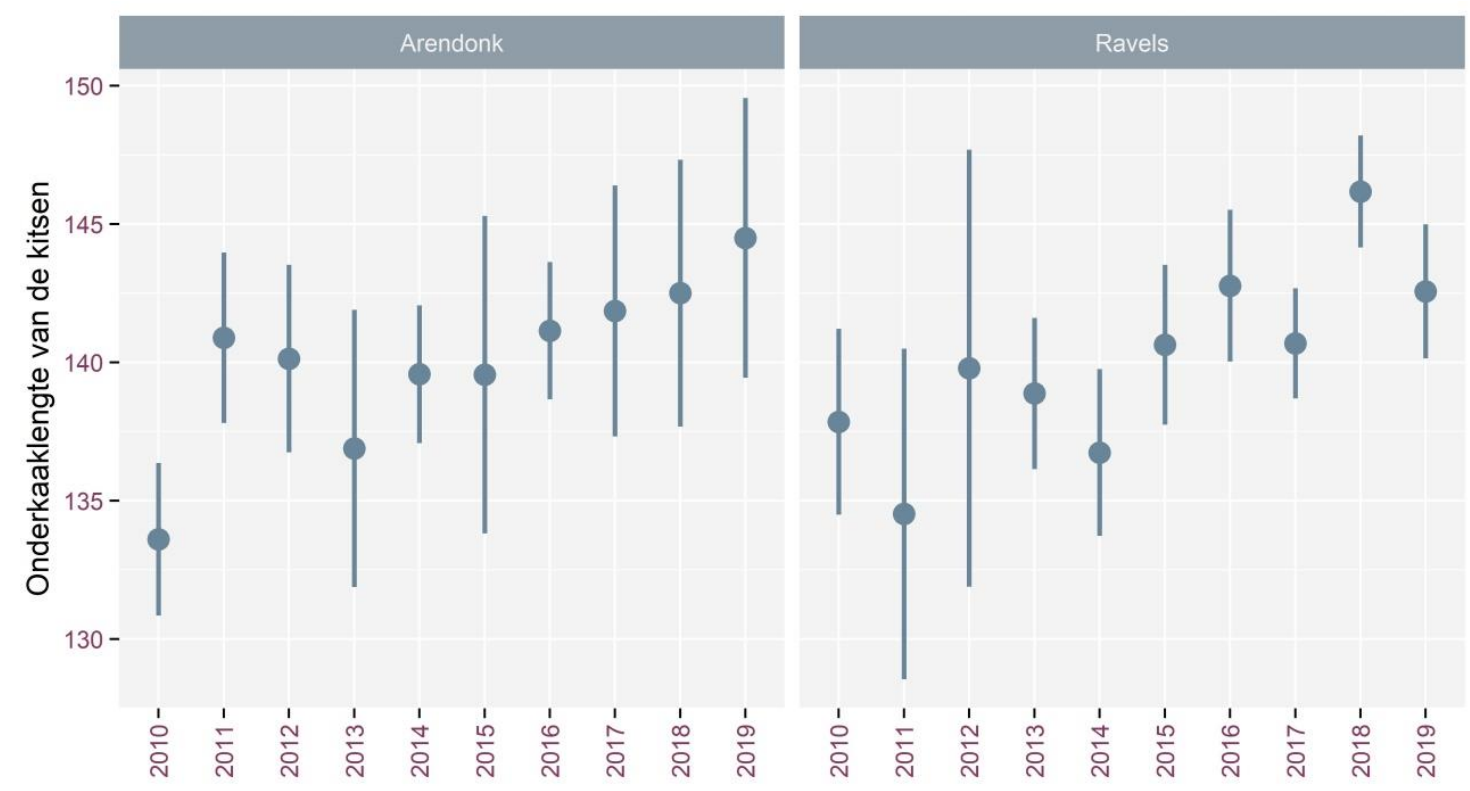

Figuur 22: Evolutie van de onderkaaklengte van de kitsen per jaar en per deelgebied. Elk punt stelt de gemiddelde waarde voor een bepaald jaar voor, de lijn het betrouwbaarheidsinterval rond deze waarde

\subsection{Aantal drachtige geiten, aantal embryo's per drachtige geit}

Tijdens het proefproject werden 147 vrouwelijke dieren ouder dan 12 maanden geschoten (46 in Arendonk en 101 in Ravels). Zowel het percentage drachtige vrouwelijk dieren ouder dan 12 maanden als het gemiddeld aantal embryo's per drachtig dieren zijn parameters die richtinggevend zijn voor de reproductiecapaciteit van de populatie. Figuur 23 geeft per jaar en per gebied de verdeling weer van het aantal embryo's per geschoten vrouwelijk dier ouder dan 12 maanden. Gezien de beperkte steekproef en het feit dat deze parameter voor reewild niet gevalideerd is, werden hier geen verdere analyses op uitgevoerd. Tabel 5 geeft het percentage drachtige vrouwelijke dieren voor elk jaar in elke gebied weer. Over de volledige proefperiode bedraagt die gemiddeld $91 \%$ voor Ravels en $84 \%$ voor Arendonk. 


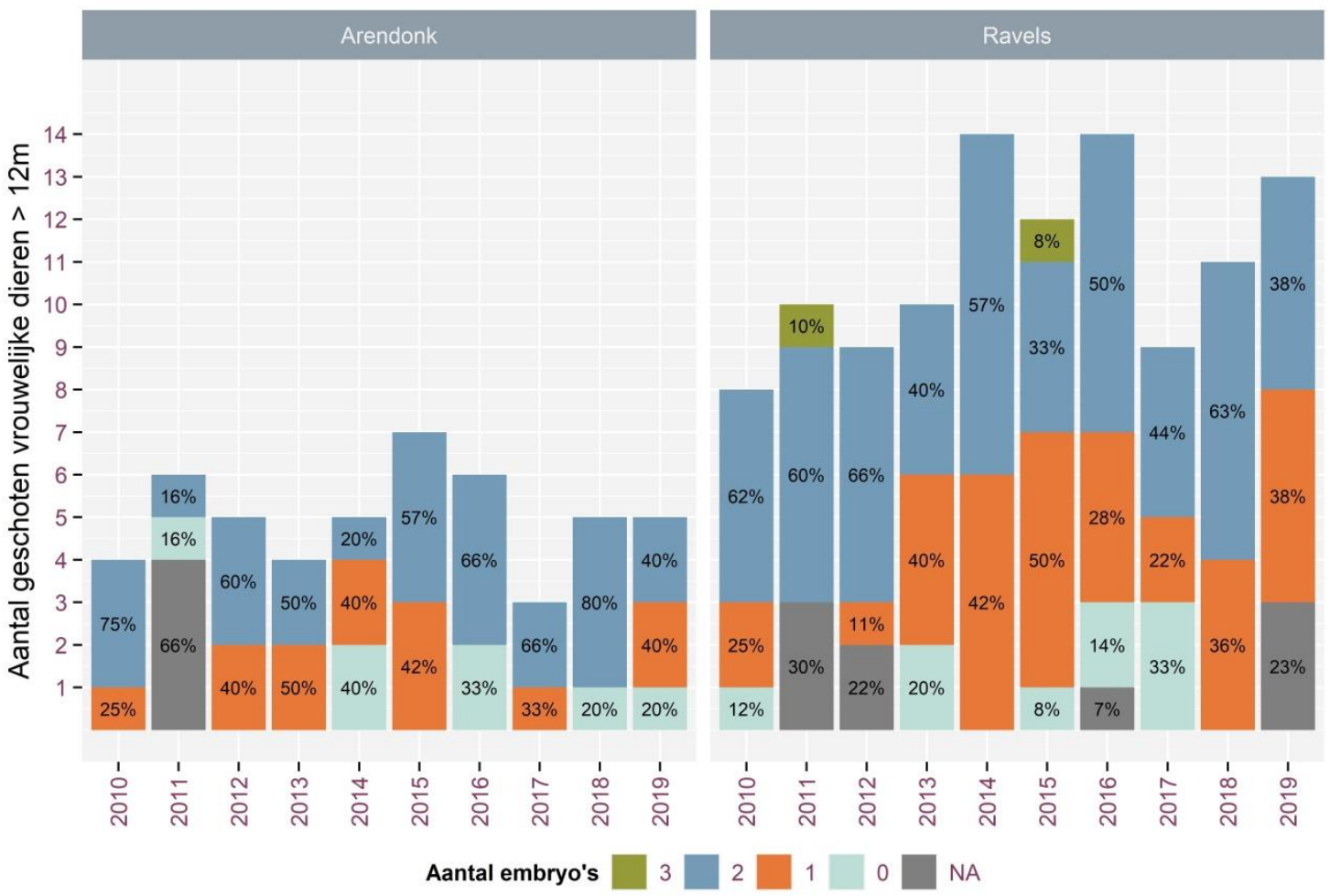

Figuur 23: Aantal embryo's per geschoten vrouwelijk dier (ouder dan 12 maanden), opgedeeld naar jaar en deelgebied. NA verwijst naar dieren waarvan het aantal embryo's niet bekend is

Tabel 5: Percentage drachtige geiten in het afschot - opgedeeld naar jaar en deelgebied (voor de steekproefgrootte zie Figuur 23)

\begin{tabular}{|c|c|c|c|c|c|c|c|c|c|c|c|}
\hline & 2010 & 2011 & 2012 & 2013 & 2014 & 2015 & 2016 & 2017 & 2018 & 2019 & Gemiddelde \\
\hline Arendonk & $100 \%$ & $50 \%$ & $100 \%$ & $100 \%$ & $60 \%$ & $100 \%$ & $67 \%$ & $100 \%$ & $80 \%$ & $80 \%$ & $84 \%$ \\
\hline Ravels & $88 \%$ & $100 \%$ & $100 \%$ & $80 \%$ & $100 \%$ & $92 \%$ & $85 \%$ & $67 \%$ & $100 \%$ & $100 \%$ & $91 \%$ \\
\hline
\end{tabular}

\subsubsection{Vergelijking met de rest van Vlaanderen, de provincie Antwerpen en de omliggende wildbeheereenheden}

Om een idee te krijgen van de toestand van de leeggewichten en onderkaaklengtes van de populatie in de licentiejacht, werden ze vergeleken met de waarden in de omliggende WBE's (Bos en Duin Kasterlee, De Vart, Groot-Lille, Merksplas, Retie, De AA, Dessel, Klei en zand, Postel Jacht en Natuur, Tulderheide), de WBE's in de provincie Antwerpen (exclusief Arendonk en Ravels) en de WBE's in heel Vlaanderen (exclusief Arendonk en Ravels). Per jaar wordt de gemiddelde waarden van de licentiejacht (Arendonk en Ravels samen) met de gemiddelde waarde van de WBE's van het betreffende gebied vergeleken. Hierbij werd telkens ook het 95\%-betrouwbaarheidsinterval berekend (Figuur 24). We zien doorheen de jaren een stabiel verloop van de leeggewichten in Vlaanderen, in de provincie Antwerpen en in de omliggende WBE's. Bij de start van het project lag het gemiddelde leeggewicht in de licentiejacht lager dan in de omliggende WBE's, Antwerpen en Vlaanderen. Naarmate het proefproject vorderde, kwam het gemiddelde leeggewicht dichter bij de waarden van de overige gebieden te liggen. Wel dient er gewezen te worden op de grootte van de betrouwbaarheidsintervallen voor de vergelijkingen. Deze wordt sterk beïnvloed door het aantal gegevens dat voor een bepaald jaar voor een bepaald gebied beschikbaar is. Het betrouwbaarheidsinterval voor Vlaanderen is 
bijgevolg kleiner dan dat voor de provincie Antwerpen dewelke op zijn beurt kleiner is dan het betrouwbaarheidsinterval voor de omliggende WBE's. De gemiddelde waarden voor de licentiejacht liggen elk jaar binnen de betrouwbaarheidsintervallen van de omliggende WBE's en de provincie Antwerpen. Dit wil zeggen dat de gemiddelde leeggewichten van de kitsen in de licentiejacht statistisch niet significant verschillen van deze in de omliggende WBE's en de provincie Antwerpen.

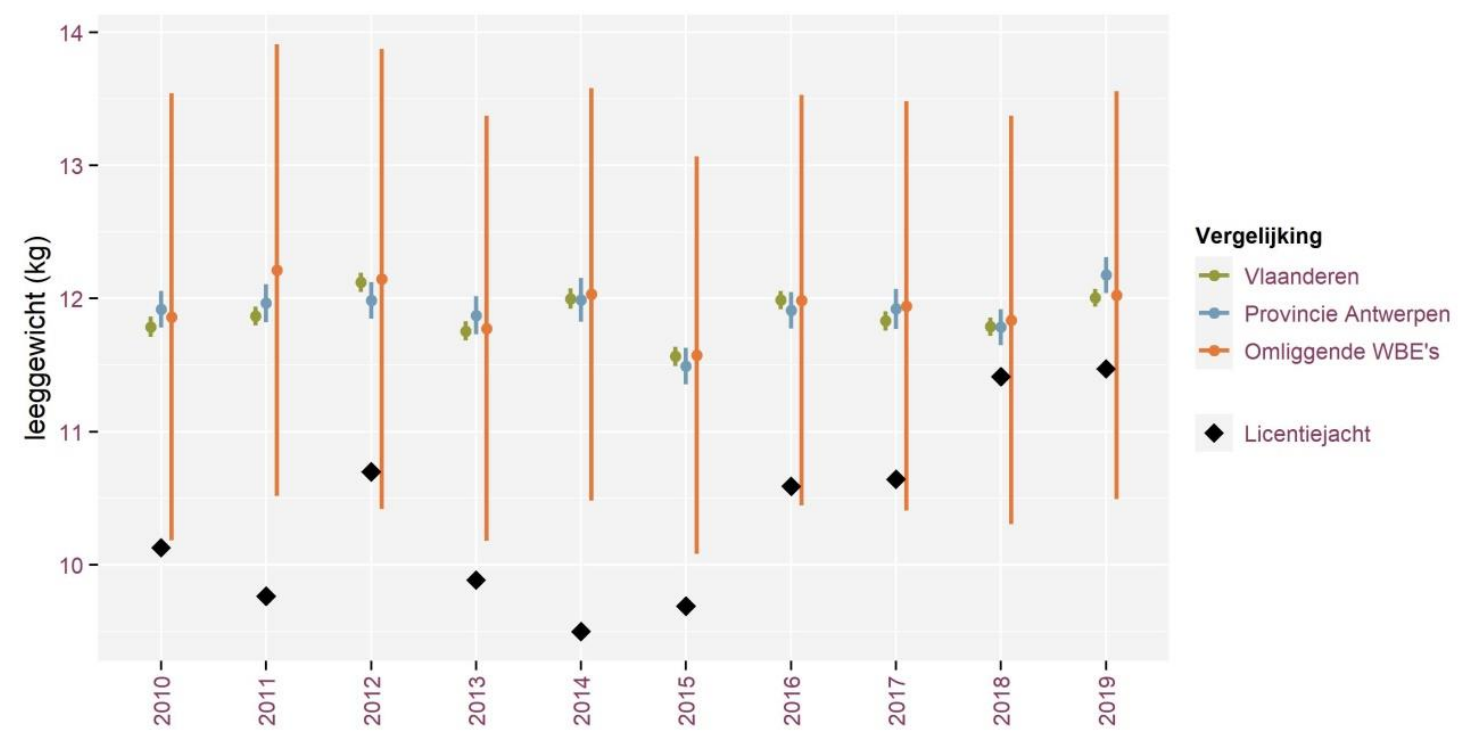

Figuur 24: Vergelijking van de leeggewichten van de kitsen binnen de licentiejacht, met leeggewichten in de omliggende WBE's, de WBE's in de provincie Antwerpen en de WBE's in heel Vlaanderen. De ruitvormige punten geven het gemiddelde van de licentiejacht aan, de bolvormige punten deze van de omliggende WBE's, de provincie Antwerpen en Vlaanderen De lijnen geven de betrouwbaarheidsintervallen aan

Om de verandering van de leeggewichten binnen de licentiejacht beter te kunnen vergelijken met veranderingen in Vlaanderen als geheel (alle WBE's samen), werd gekeken naar de trend in combinatie met de toestand in het startjaar. Hiervoor werd de mediaan van de leeggewichten in 2010 zowel binnen de licentiejacht als voor de andere WBE's in Vlaanderen berekend. Voor die WBE's waarvoor de gegevens over leeggewichten pas na 2010 geregistreerd werden, werd de startwaarde berekend voor het eerste beschikbare jaar. Daarnaast werd ook de richtingscoëfficiënt. Dat is een maat voor de verandering van de leeggewichten in functie van de tijd, waarbij positieve waarden duiden op een stijgende trend en negatieve op een dalende trend. Op basis hiervan kunnen de WBE's in vier kwadranten ingedeeld worden: een kwadrant met WBE's met een laag leeggewicht in het startjaar en met een dalende trend over de onderzoeksperiode, een kwadrant met WBE's met een lage startwaarde maar met een stijging in de leeggewichten over de duur van het project en dan twee kwadranten met WBE's met hoge leeggewichten bij aanvang, waarvan een deel een daling in het leeggewicht vertonen en andere een verdere stijging. Hoe verder een punt van de nulwaarde op de y-as ligt, hoe sterker de stijging of de daling. De positie op de $x$-as geeft aan in welke mate de startwaarde verschilt van het gemiddelde voor Vlaanderen.

Uit Figuur 25 blijkt dat de licentiejacht zich bevindt in de groep van WBE's/jachtgebieden gekenmerkt door een laag leeggewicht bij aanvang, in combinatie met een stijging doorheen de jaren. Dit beeld bevestigt wat Figuur 24 reeds illustreerde. 33\% van alle WBE's in Vlaanderen bevonden zich in een dergelijke situatie in diezelfde periode. Tegelijk maakt Figuur 25 ook duidelijk dat, in tegenstelling tot wat blijkt voor de licentiejacht, $61 \%$ van de WBE's in 
de onderzochte periode gekenmerkt werden door een dalende trend in de leeggewichten van de kitsen.

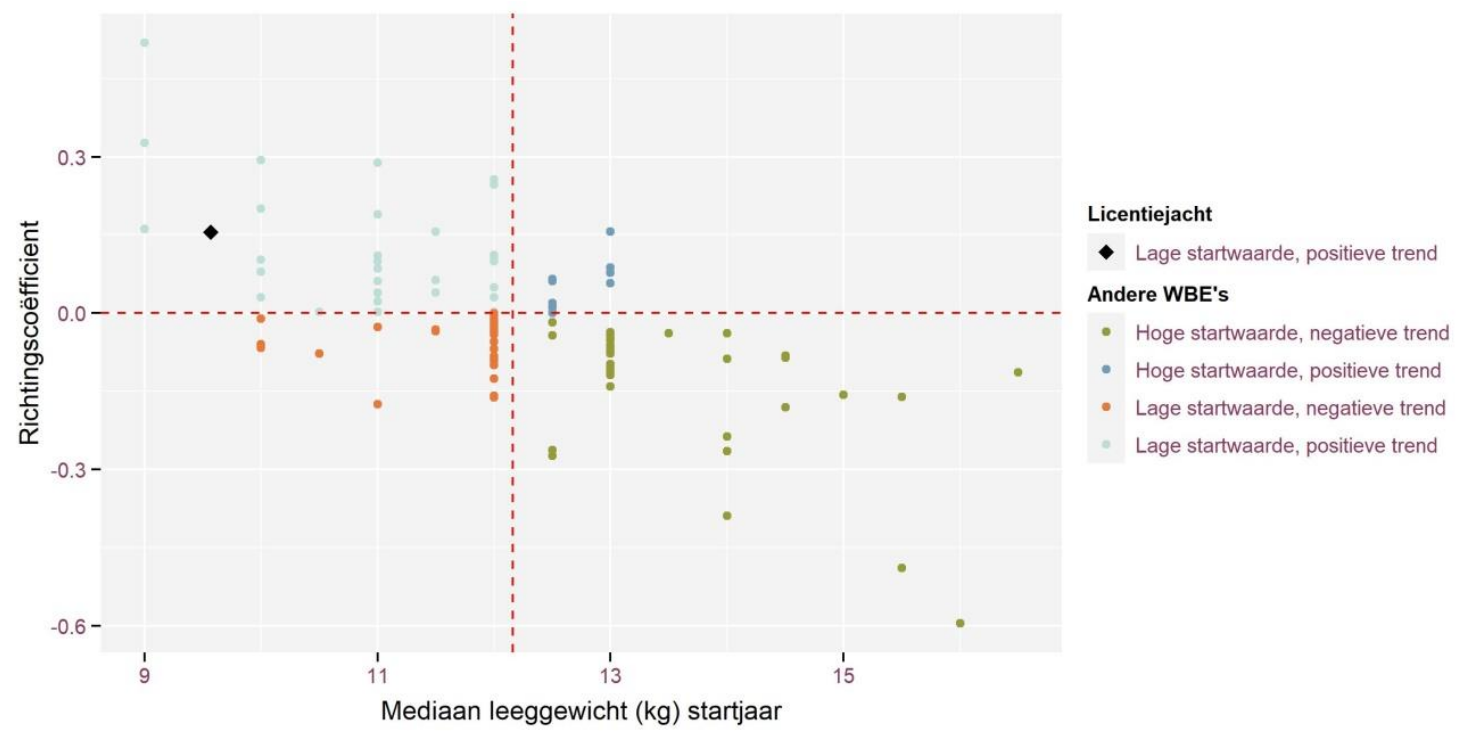

Figuur 25: Vergelijking van de trend in leeggewicht van de kitsen tussen WBE's in Vlaanderen (elk punt is een WBE) tijdens de duur van het licentiejachtproject. De mediaan van het leeggewicht als startwaarde wordt vergeleken met de richtingscoëfficiënt dewelke de evolutie in leeggewicht weergeeft. De verticale rode stippellijn duidt de gemiddelde mediaan over alle WBE's aan. Deze lijn maakt de opdeling tussen WBE's met een lage startwaarde (links van de lijn) en deze met een hoge startwaarde (rechts van de lijn). De horizontale stippellijn duidt een richtingscoëfficiënt van 0 aan. Deze lijn maakt de opdeling tussen WBE's met een positieve trend doorheen de jaren (boven de lijn) en deze met een negatieve trend (onder de lijn). Hoe verder een punt van de nulwaarde op de y-as ligt, hoe sterker de stijging of daling

Ook de verandering in de onderkaaklengtes doorheen de periode van het licentiejacht project werd op dezelfde manier vergeleken met deze in de omliggende WBE's, de WBE' $s$ in de provincie Antwerpen en de WBE's in Vlaanderen (Figuur 26). Ook hier blijkt dat de onderkaaklengtes in Ravels en Arendonk bij aanvang lager lagen dan deze in de andere gebieden. In de loop van het project stegen de waarden om uiteindelijk boven de gemiddelde onderkaaklengtes van de vergelijkende gebieden uit te stijgen. Sinds 2015 gebeurt het opmeten van de onderkaaklengtes over heel Vlaanderen gestandaardiseerd en worden de metingen gecontroleerd. Dus vooral vanaf 2015 is een zeer correcte vergelijking mogelijk. Voor de leeggewichten is op dit moment wel een vergaande standaardisatie doorgevoerd, maar controle van de data is niet mogelijk. 


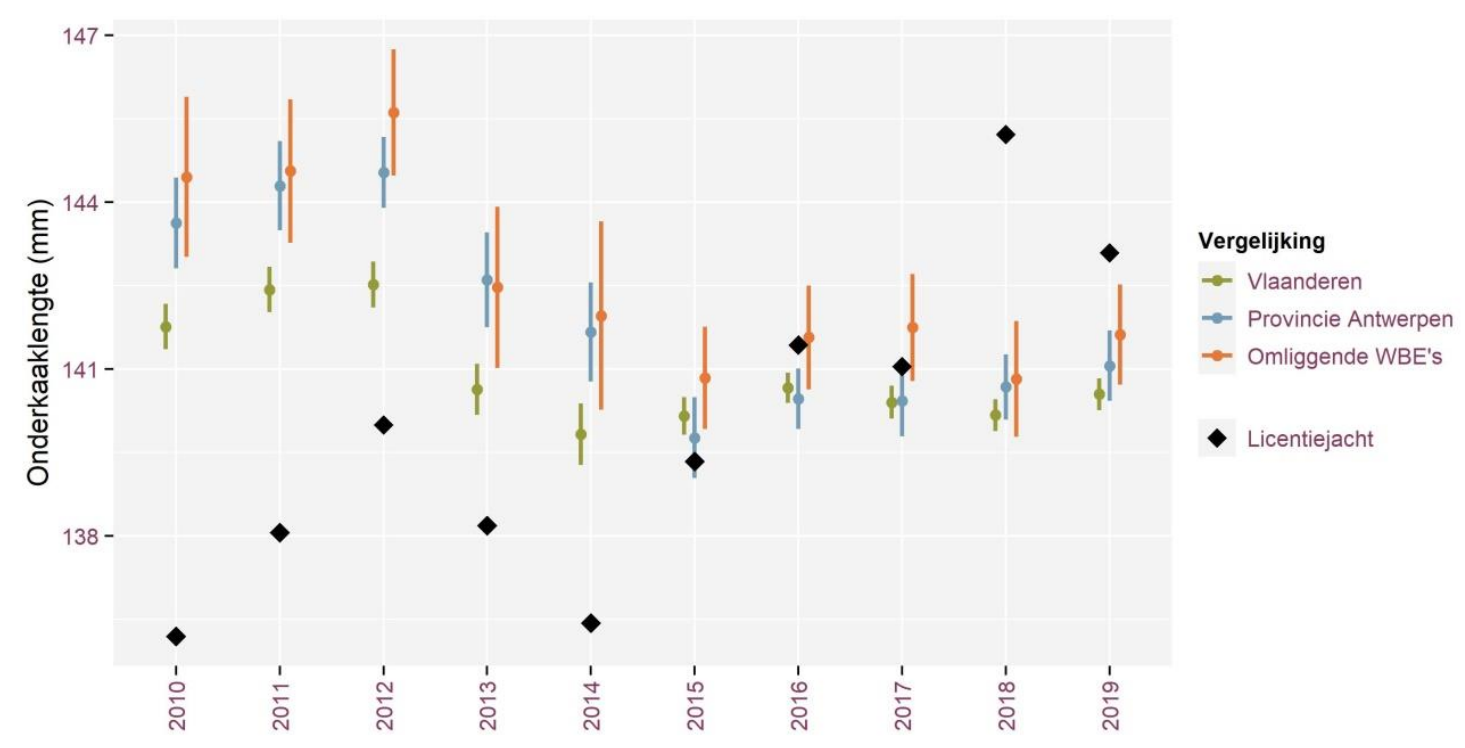

Figuur 26: Evolutie van de onderkaaklengtes van kitsen tijdens het licentiejachtproject in vergelijking met onderkaaklengtes in de omliggende WBE's, de provincie Antwerpen en Vlaanderen. De ruitvormige punten geven het gemiddelde van de licentiejacht aan, de bolvormige punten deze van de omliggende WBE's, de provincie Antwerpen en Vlaanderen. De lijnen geven de betrouwbaarheidsintervallen aan

Ook deze trend in onderkaaklengte werd op dezelfde manier als bij de leeggewichten vergeleken met andere WBE's in Vlaanderen. Hierbij zien we dat de onderkaaklengtes binnen de licentiejacht opnieuw gekenmerkt worden door een lage startwaarde en een toename doorheen de jaren (Figuur 27). Eenzelfde beeld zien we bij 34\% van alle WBE's in Vlaanderen. $54 \%$ van de wildbeheereenheden werden in diezelfde periode gekenmerkt door een dalende trend in de lengte van de onderkaken van de kitsen.

Zowel voor de onderkaken als voor de leeggewichten van de kitsen dient opgemerkt te worden dat deze vergelijking vooral indicatief is. Er wordt in deze figuur immers uitgegaan van een lineair effect om de trendanalyse mee uit te voeren en de significantie van de gevonden parameters werd hier niet mee getest. Een meer diepgaande analyse lag echter buiten het doel van dit rapport. 


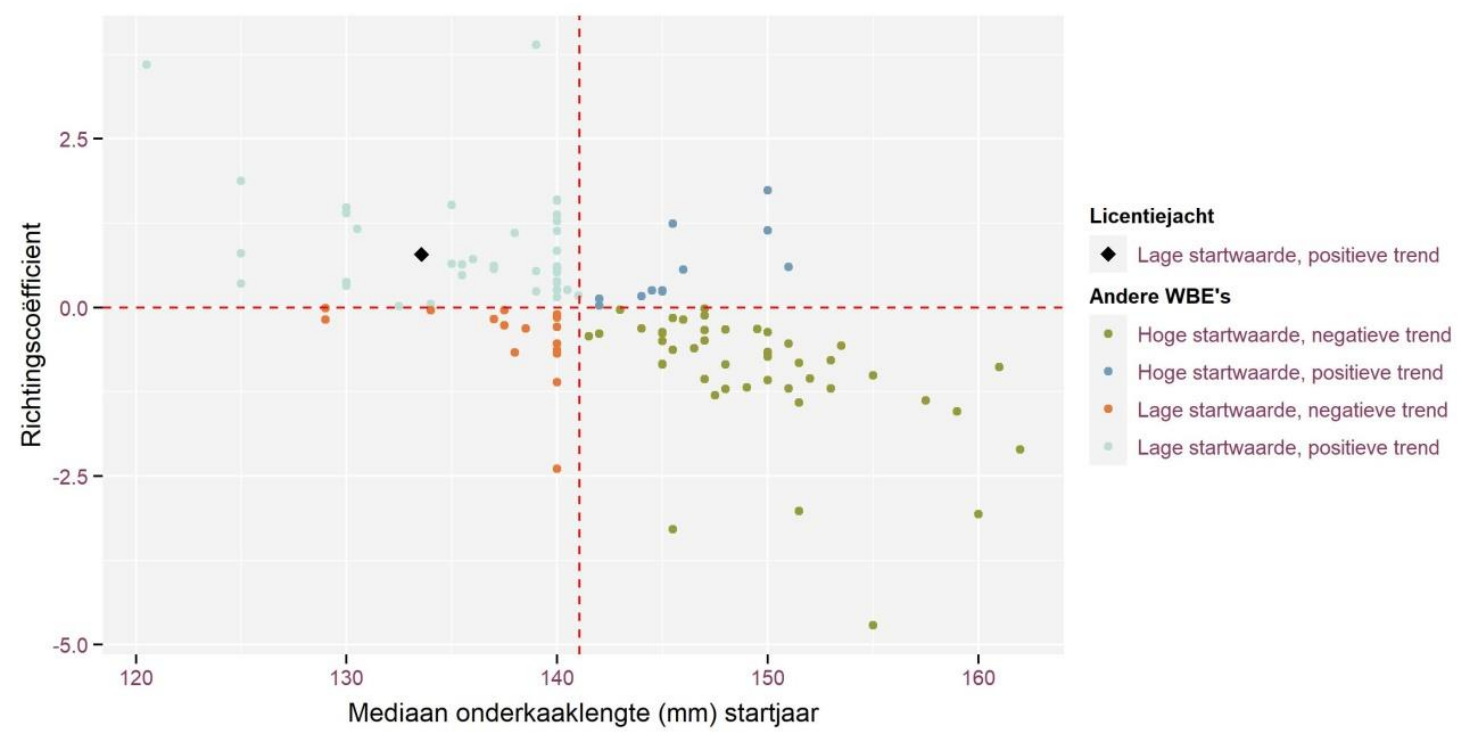

Figuur 27: Vergelijking van de trend in onderkaaklengte van de kitsen tussen de WBE's in Vlaanderen (elk punt is een WBE) tijdens de duur van het licentiejachtproject. De mediaan van de onderkaaklengte als startwaarde wordt vergeleken met de richtingscoëfficiënt dewelke de evolutie in onderkaaklengte weergeeft. De verticale rode stippellijn duidt de gemiddelde mediaan over alle WBE's aan. Deze lijn maakt de opdeling tussen WBE's met een lage startwaarde (links van de lijn) en deze met een hoge startwaarde (rechts van de lijn). De horizontale stippellijn duidt een richtingscoëfficiënt van 0 aan. Deze lijn maakt de opdeling tussen WBE's met een positieve trend doorheen de jaren (boven de lijn) en deze met een negatieve trend (onder de lijn). Hoe verder een punt van de nulwaarde op de y-as ligt, hoe sterker de stijging of daling

\subsubsection{Conclusie effect op de populatie}

De evolutie van de onderkaaklengtes en leeggewichten van de kitsen gedurende het proefproject, wijst op een verbetering van de verhouding tussen de draagkracht van het gebied en de aanwezige reepopulatie. Een vergelijking met de beschikbare data van de WBE's in de rest van Vlaanderen wijst op een een relatief hoge reewildstand in vergelijking tot de draagkracht van het gebied bij aanvang van het project in 2010. Kenmerkend hiervoor zijn de relatief lagere kitsgewichten en onderkaaklengtes dan het gemiddelde gerapporteerd door andere wildbeheereenheden. De doelstelling om verbetering te brengen in de verhouding tussen de draagkracht van het gebied en het aantal aanwezige reeën, lijkt dus op basis van deze twee gevalideerde bio-indicatoren geslaagd te zijn.

lets meer dan een derde van de WBE's in Vlaanderen vertoonde in de periode 2010-2019 eenzelfde combinatie van lage startwaarden en een positieve trend van beide bioindicatoren.

\section{$5.4 \quad$ REEVRAAT}

Opmerking : Dit deel van het rapport is slechts in beperkte mate uitgewerkt door de langdurige afwezigheid van de onderzoekster die verantwoordelijk was voor dit deel van het proefproject. Met de rest van het team willen we in onderstaand deel de basisresultaten van het opmaken van de reevraatindex meegeven. Een meer uitgebreide rapportering over de gevolgde methode en een bespreking in detail van alle opnames binnen en buiten kleine reewildwerende rasters, zowel als de methodologische aspecten ervan, hopen we op latere datum te kunnen realiseren. 


\subsubsection{Inleiding}

Naast de bio-indicatoren die rechtstreeks gelinkt zijn aan de reepopulatie, is ook bosverjonging een waardevolle bio-indicator in het kader van het reewildbeheer(Michallet et al., 2015; Morellet et al., 2001; Morellet et al., 2007). Reevraat aan houtige gewassen kan een negatieve invloed hebben op de realisatie van bosdoeltypes, waarbij een te hoge reevraat aanleiding kan geven tot onaanvaardbare schade aan bosverjonging. De oppervlaktedoelen voor habitattype 9190 zullen in de Antwerpse Kempen voor een groot deel verwezenlijkt moeten worden door de omvorming van naaldhout naar loofhout op basis van eik via natuurlijke verjonging. Een hoge reewilddruk vormt hiervoor een hindernis omdat loofhoutverjonging selectief begraasd wordt.

Om inzicht te krijgen in de druk op de bosverjonging door reewild, werd gebruik gemaakt van een vraatindex ICE (Indice de consommation (ONCFS, 2015a)). Deze vraatindex geeft een beeld van de druk die reewild uitoefent op een bos, door de verhouding te bepalen van het aandeel aangevreten houtige planten met de totale aanwezigheid van deze houtige planten. Hiervoor wordt gebruik gemaakt van 'plots' die ad random verdeeld worden in het bos. De ICE wordt vervolgens berekend door voor alle houtige gewassen samen (of een subgroep ervan) de verhouding te berekenen tussen de plots waar de soorten voorkomen en aangevreten zijn en deze waar de soorten aanwezig zijn. De ICE kan ook voor één specifieke soort of voor een soortengroep (bv. loofboomsoorten) berekend worden.

$$
I C E=\frac{\text { aantal plots houtige gewassen met vraat }+1}{\text { aantal plots houtige gewassen }+2}
$$

Zowel in Ravels als in Arendonk werden telkens minstens 150 punten at random uitgekozen. Voor bepaalde punten werden omwille van voorafvastgestelde criteria (geen bos aanwezig, afgesloten door omheining, te jong, rand of punten op de weg) geen opnames uitgevoerd (Tabel 6). Op alle andere punten werd de aanwezigheid en vraat van houtige gewassen opgemeten binnen een plot van $1 \mathrm{~m}^{2}$. De houtige gewassen omvatten naast boomsoorten ook bosbes, heide, hulst, braam, kamperfoelie en sporkehout. Binnen elke plot werd voor elke aanwezige soort de maximale hoogte, bedekkingsgraad en de aan- of afwezigheid van vraat genoteerd. De at random gekozen punten werden een eerste keer in 2016 bezocht en een tweede keer in 2019. Hierdoor kon een mogelijke evolutie van de ICE-waarde over 3 jaar worden aangetoond. Het opnemen van deze bio-indicator startte pas in 2016, m.a.w. op het moment dat het proefproject reeds 6 jaar liep. Hierdoor werd de vertreksituatie niet opgemeten en kan het effect van het reewildbeheer slechts gedeeltelijk geëvalueerd worden.

Tabel 6: Het aantal random gekozen punten en het aantal opgenomen punten per gebied in 2016 en 2019

\begin{tabular}{|c|c|c|c|}
\hline & $\begin{array}{l}\text { Totaal aantal random } \\
\text { gegenereerde punten }\end{array}$ & $\begin{array}{l}\text { Aantal opgenomen } \\
\text { punten } 2016\end{array}$ & $\begin{array}{l}\text { Aantal herhaalde punten } \\
2019\end{array}$ \\
\hline Arendonk & 210 & 179 & 173 \\
\hline Ravels & 339 & 283 & 271 \\
\hline
\end{tabular}

\subsubsection{Resultaten}

In een meerderheid van de opgenomen plots komen geen houtige plantensoorten voor. Bij de tweede opname (2019) is er een beperkte afname van deze categorie, zowel in Ravels als in Arendonk, maar de afname is niet significant is (de afname bevindt zich binnen de betrouwbaarheidsintervallen) (Figuur 28). In Arendonk stijgt het aantal plots met vraat (van $26,3 \%$ in 2016 tot $30,6 \%$ in 2019) terwijl er in Ravels een afname van het aantal plots met vraat waar te nemen is (van $24,7 \%$ in 2016 naar $21,4 \%$ in 2019) al zijn beide trends niet significant. 
Het aantal plots zonder vraat neemt zowel in Ravels als in Arendonk in beperkte mate toe (maar ook niet significant).

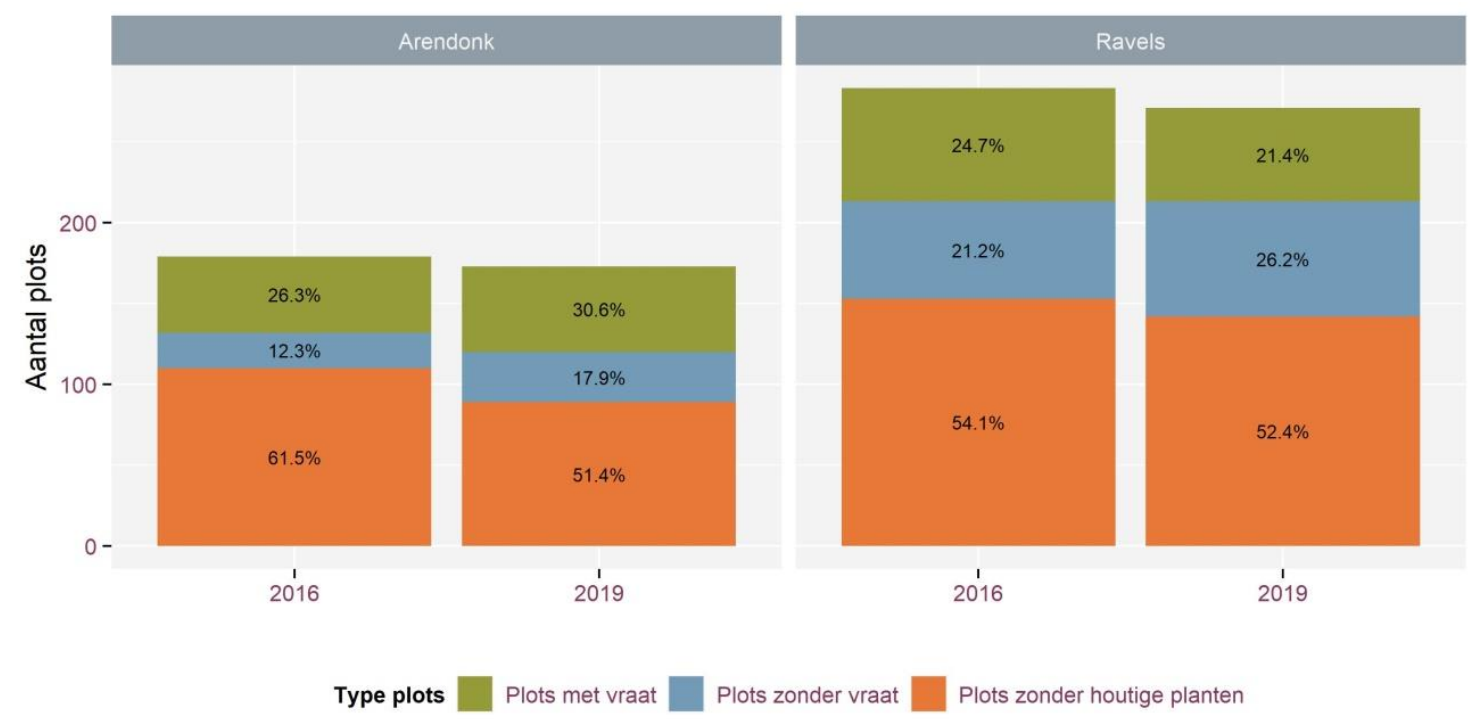

Figuur 28: Aantal plots met vraat, zonder vraat en aantal plots zonder houtige planten opgenomen in 2016 en 2019

De verdeling van de verschillende types houtige gewassen vertoont lichte variaties doorheen de jaren, al zijn deze niet significant (met uitzondering van een significante toename in plots met struikgewas in Arendonk) (Figuur 29).

De meeste plots waarin houtige gewassen voorkomen bevatten loofhout of naaldhout, een klein deel bevat zowel loof- als naaldhout. Slechts een beperkt deel van de plots bevatte enkel houtige struikgewassen.
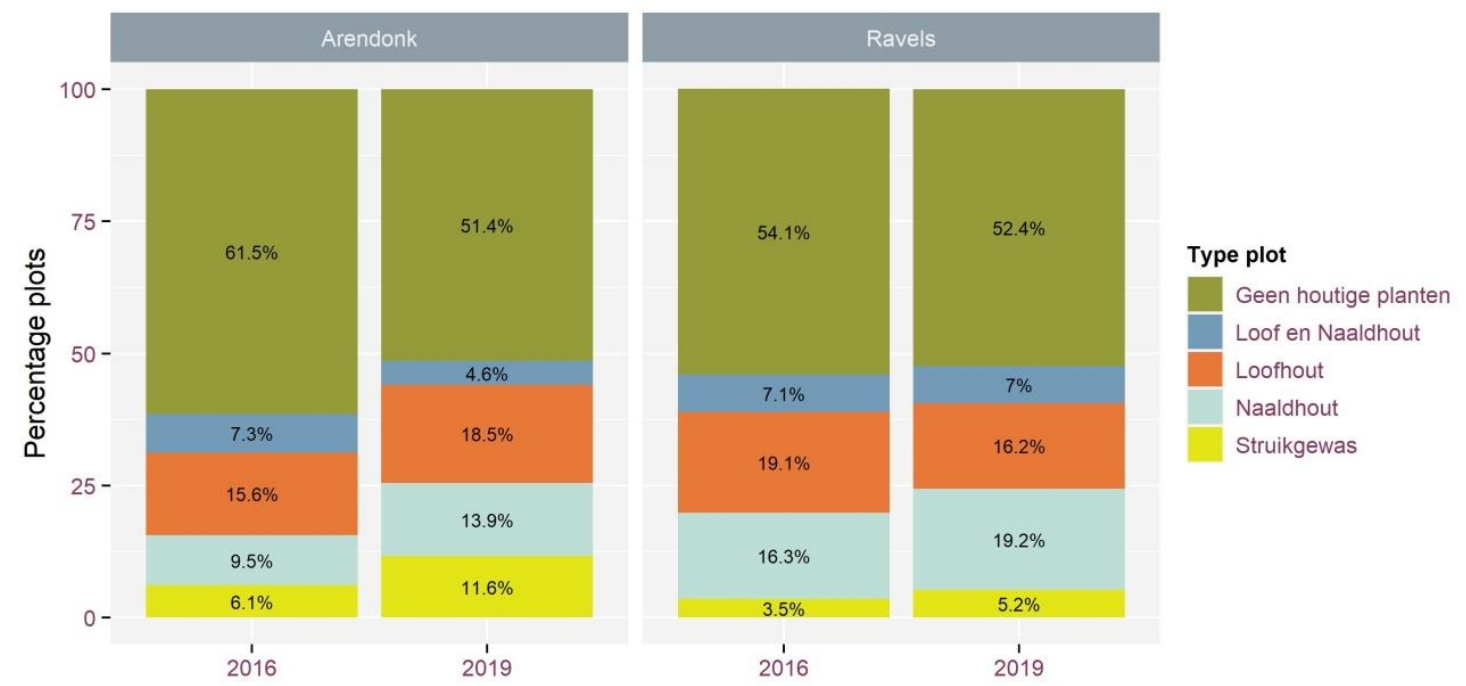

Figuur 29: Verdeling van de verschillende type houtige gewassen in de opgenomen plots

Om een beeld te krijgen van een eventuele verandering in reevraat tussen 2016 tot 2019, werd de ICE-waarde per jaar voor elk van beide deelgebieden berekend (Figuur 30). Hoewel de gemiddelde ICE-waarde per gebied een daling vertoont in 2019 ten opzichte van 2016, valt 
deze daling voor beide gebieden binnen het 95\%-betrouwbaarheidsinterval. De daling is dus niet statistisch significant. Arendonk heeft zowel in 2016 als in 2019 een hogere ICE-waarde dan Ravels, wat duidt op een hogere reevraatdruk.

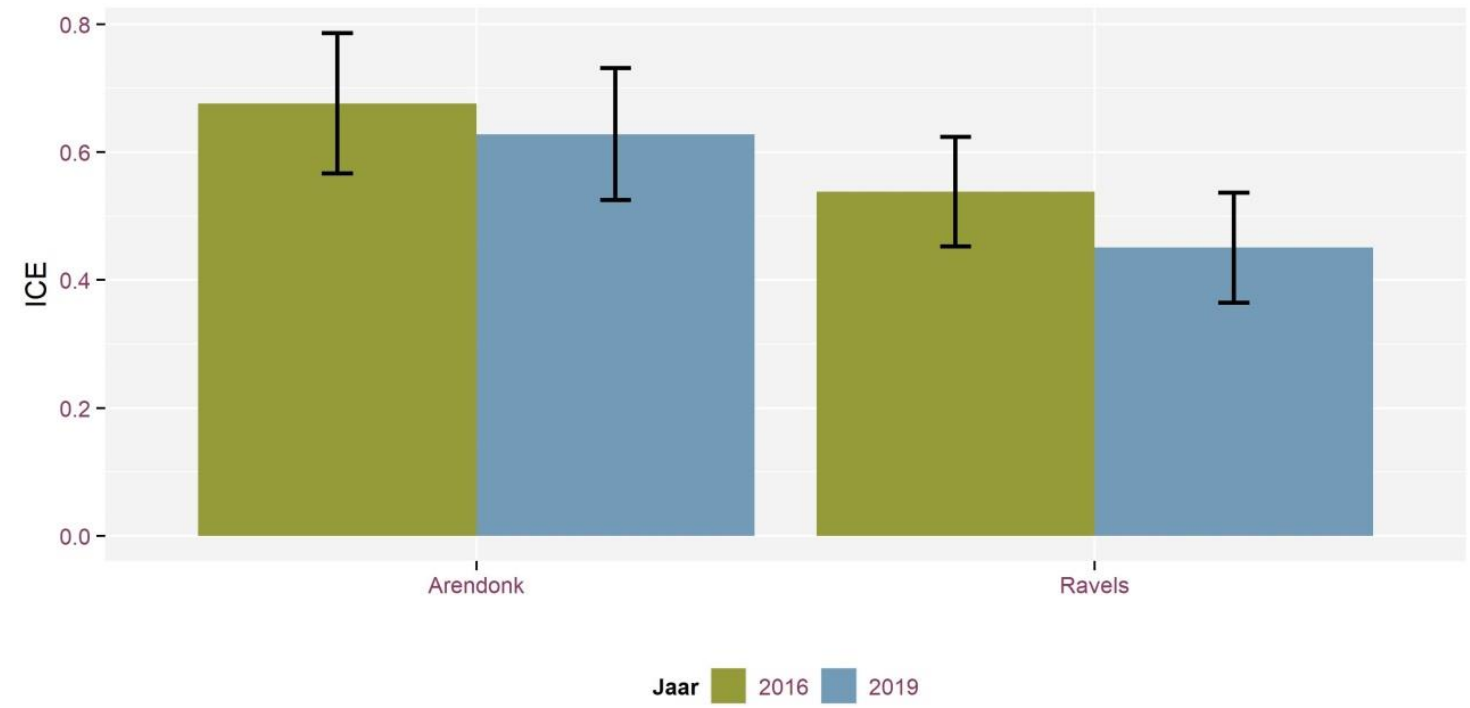

Figuur 30: ICE als maat voor reevraat in Arendonk en Ravels. De balken geven de ICE-waarde weer en de zwarte lijnen de betrouwbaarheidsintervallen

Gezien het streefdoel om de oppervlaktedoelen voor habitattype 9190 te halen door omvorming van naaldhout naar loofhout via natuurlijke verjonging, werd ook de ICE-waarde specifiek voor loofboomsoorten berekend. De ICE-waarde is in beide gebieden hoger voor loofhout (Figuur 31) dan voor houtige gewassen in het algemeen (Figuur 30). Ook voor loofhout is de daling in reevraat tussen 2016 en 2019 niet significant en ligt de druk door reevraat hoger in Arendonk dan in Ravels. In Ravels lijkt de druk op de loofboomsoorten hetzelfde gebleven te zijn.

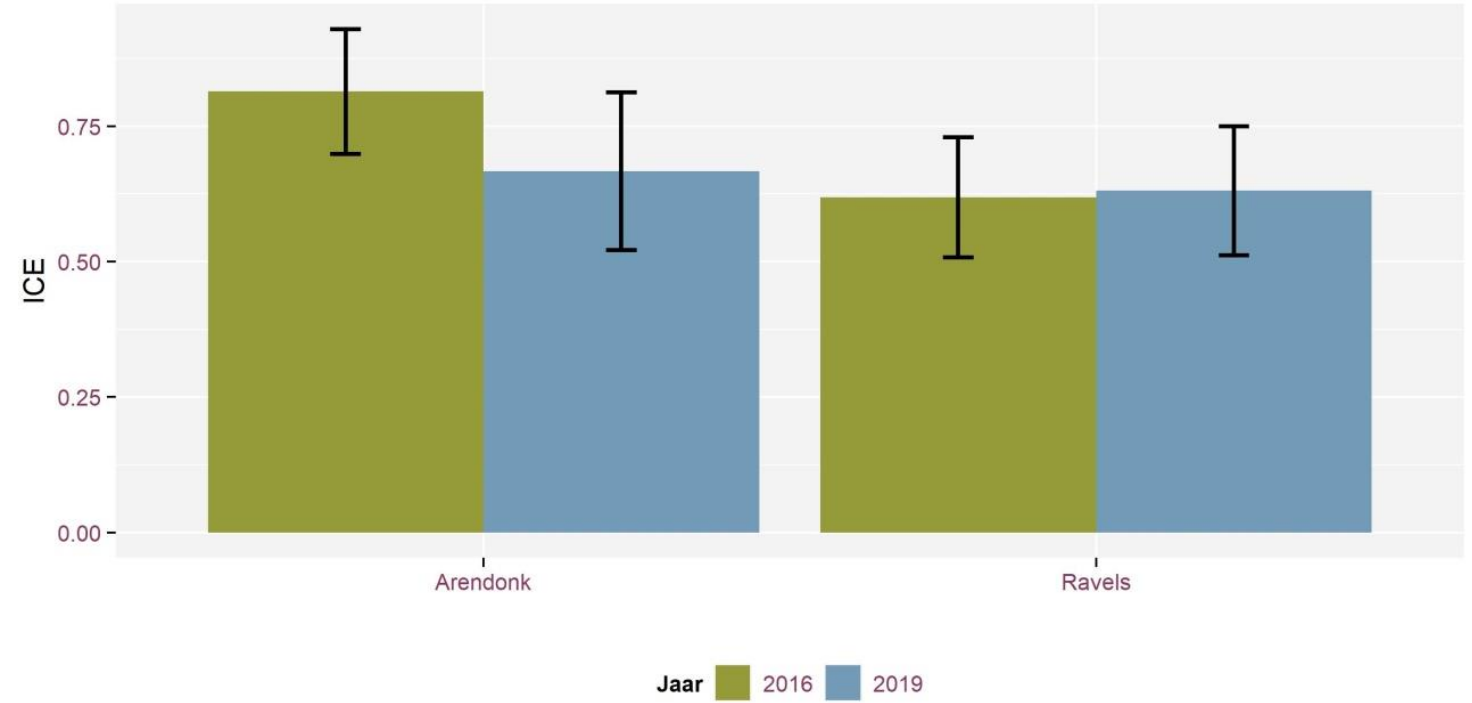

Figuur 31: ICE evolutie specifiek voor loofhout in Arendonk en Ravels. De balken geven de ICE-waarde weer en de zwarte lijnen de betrouwbaarheidsintervallen 
Als laatst werd ook de reevraatdruk per houtige soort bekeken. Hiervoor werd enkel de ICEwaarde berekend van soorten die in minstens $5 \%$ van de plots voorkomen. Het ONCFS (2015b)raadt zelfs aan om enkel ICE-waarden te berekenen voor die soorten die minstens in $10 \%$ van de plots voorkomen. De hoogste ICE-waarden (hoogste vraatdruk) werden waargenomen voor bramen, berk, wilde lijsterbes en Amerikaanse eik (Figuur 32). Voor sommige soorten (bramen, berk, lork, den) is er een afname in de gemiddelde ICE-waarde, voor andere een toename (wilde lijsterbes, Amerikaanse eik, Douglas). Met uitzondering voor Douglas is geen enkele verandering significant. De grote betrouwbaarheidsintervallen, waardoor er bijna geen significante trends zijn waar te nemen, kunnen deels worden verklaard door het lage aantal plots waarin sommige soorten zijn waargenomen.

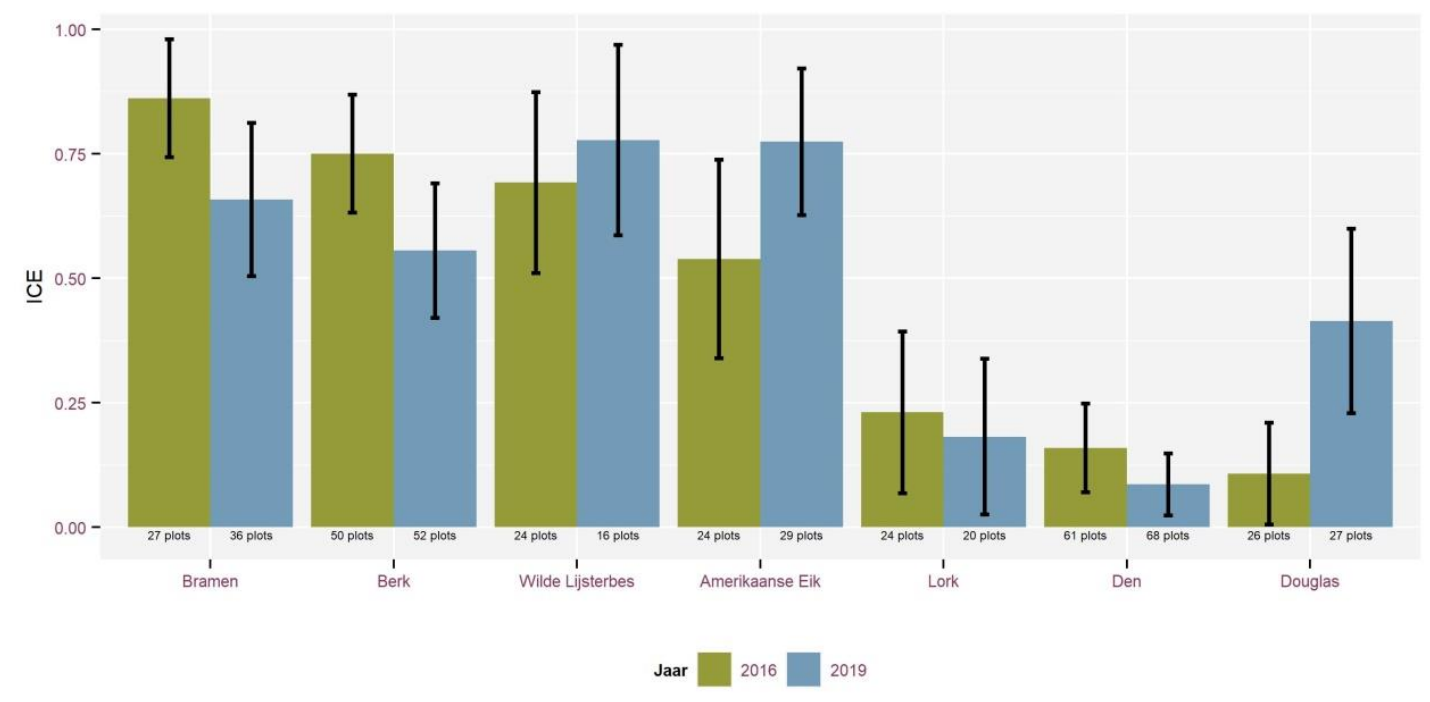

Figuur 32: ICE evolutie per houtige soort (enkel voor soorten die in minstens $5 \%$ van de plots voorkomen in beide jaren). De balken geven de ICE-waarde weer en de zwarte lijnen de betrouwbaarheidsintervallen

\subsubsection{Conclusie reevraat}

De vergelijking van de reevraatindex (ICE) tussen 2019 en 2016 toont een lichte, maar niet significante, daling wanneer alle houtige gewassen in beschouwing genomen worden. Indien enkel de loofboomsoorten in beschouwing genomen worden is dit effect in Ravels niet meer te zien. Algemeen lijkt de druk door de reeën in Arendonk hoger te zijn dan in Ravels. De druk op de loofboomsoorten en braam is hoger dan op den en lork. Algemeen dienen twee opmerkingen gemaakt te worden: i) De eerste opname vond pas in 2016 plaats en niet bij de start van het project. Dat maakt het onmogelijk om het effect van het beheer en de vermindering van de reewildstand goed te evalueren. Het verderzetten van het opmeten van de reevraat is daarom aan te raden, ii) opvallend is het hoge percentage plots waar helemaal geen houtige gewassen voorkomen. Dit bemoeilijkt de interpretatie van de data gezien er daardoor maar een beperkte steekproef is van plots waar de soorten voorkomen. Een beter begrip van de reden waarom er geen houtige gewassen voorkomen is dan ook belangrijk. Mogelijke opties zijn een algemene hoge reevraat op de zaailingen dan wel een vergrassing die het vestigen van zaailingen onmogelijk maakt. 


\section{EVERZWIJNEN IN HET PROJECTGEBIED}

\section{$6.1 \quad$ INLEIDINING}

Sinds 2006 zijn everzwijnen opnieuw aanwezig in Vlaanderen. Vanaf 2013 werden ze ook waargenomen in het projectgebied. Het eerste afschot op everzwijnen in het projectgebied dateert van 2015. Om een exponentiële toename van de everzwijnenpopulatie te vermijden, organiseerde het ANB in samenwerking met naburige jagers, landbouwers en lokale besturen vanaf 2017 drukjachten. Licentiehouders konden hier aan deelnemen. Net zoals bij reewild werd verplicht om waarnemingen en afschot van everzwijnen te noteren in de jachtdagboekjes van het licentiejachtproject.

Aangezien de aanwezigheid van everzwijnen vrij recent is en dit rapport focust op reewildbeheer als hoofddoelstelling van het licentiejachtproject, worden in dit hoofdstuk de bevindingen kort beschreven. Uitgebreide analyses van populatiestructuur etc. werden hier niet uitgewerkt.

\subsection{EVOLUTIEEVERZWIJNEN}

Sinds de eerste waarneming van everzwijn tijdens een aanzit in 2015 (Figuur 33), is er een duidelijke sterke toename doorheen de jaren. Deze toename is meer uitgesproken in Ravels dan in Arendonk.

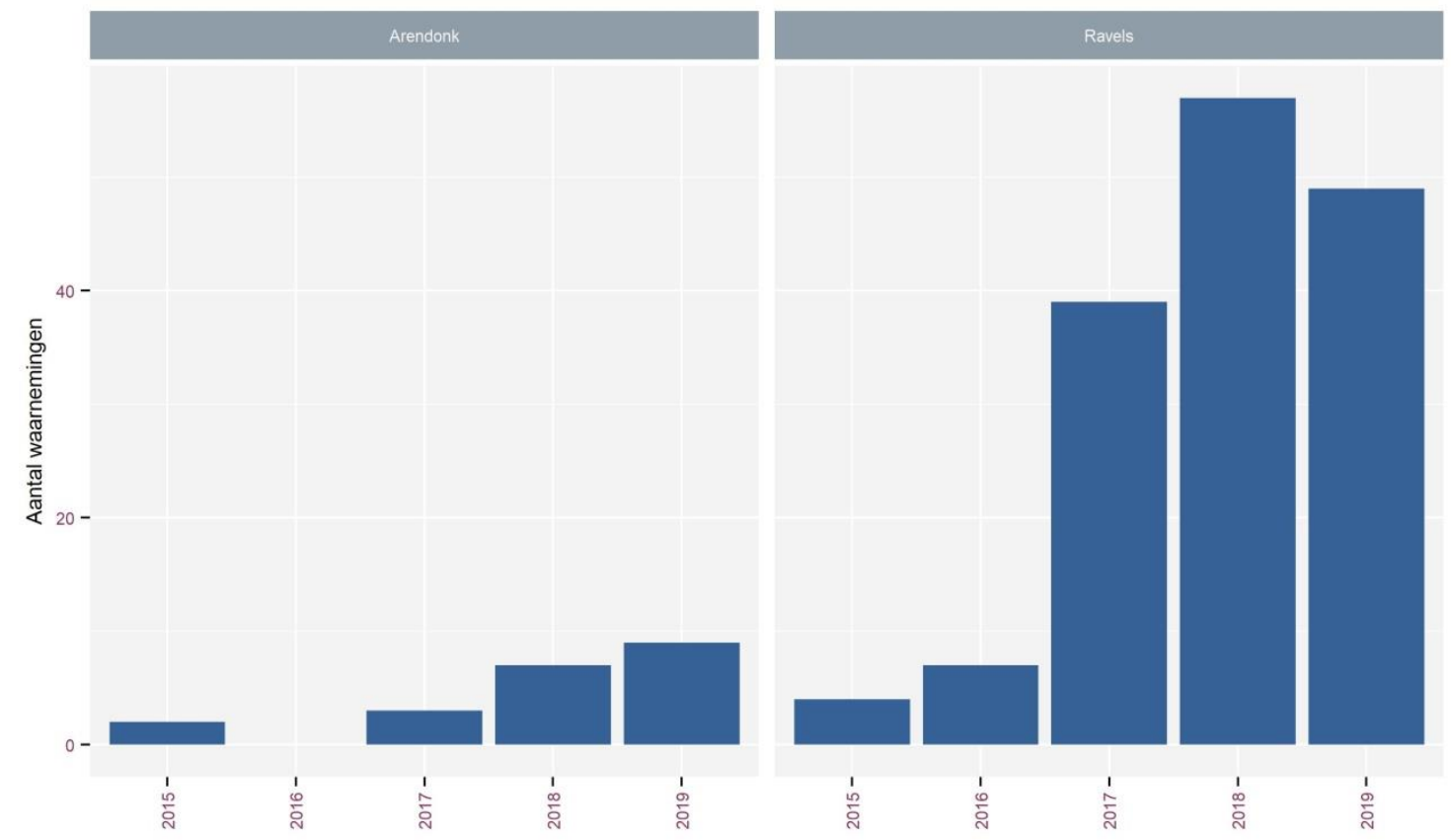

Figuur 33: Evolutie van het aantal waarnemingen van everzwijn op basis van de data uit de jachtdagboekjes. Deze grafiek toont het aantal keren dat everzwijnen werden waargenomen en niet het aantal waargenomen everzwijnen

In 2015 werden 5 everzwijnen geschoten in het projectgebied. Dit aantal steeg tot 27 in 2019, waarbij het grootste aandeel uit frislingen bestond (Figuur 34). Het grootste deel van het jaarlijks afschot wordt gerealiseerd tijdens de drukjachten (Tabel 7). In 2019 werden ook 
kooien ingezet. In vergelijking met andere gebieden en WBE's waar drukjachten op everzwijnen worden georganiseerd, is het aandeel van het afschot dat tijdens drukjachten wordt gerealiseerd, binnen het projectgebied vrij hoog (Figuur 35).

Tabel 7: Overzicht van de georganiseerde drukjachten in het projectgebied en het aantal tijdens die drukjachten geschoten everzwijnen

\begin{tabular}{ll}
\hline Datum & Aantal everzwijnen \\
\hline $13 / 11 / 2017$ & 13 \\
$13 / 11 / 2018$ & 1 \\
$27 / 11 / 2018$ & 9 \\
$13 / 11 / 2019$ & 10
\end{tabular}

a

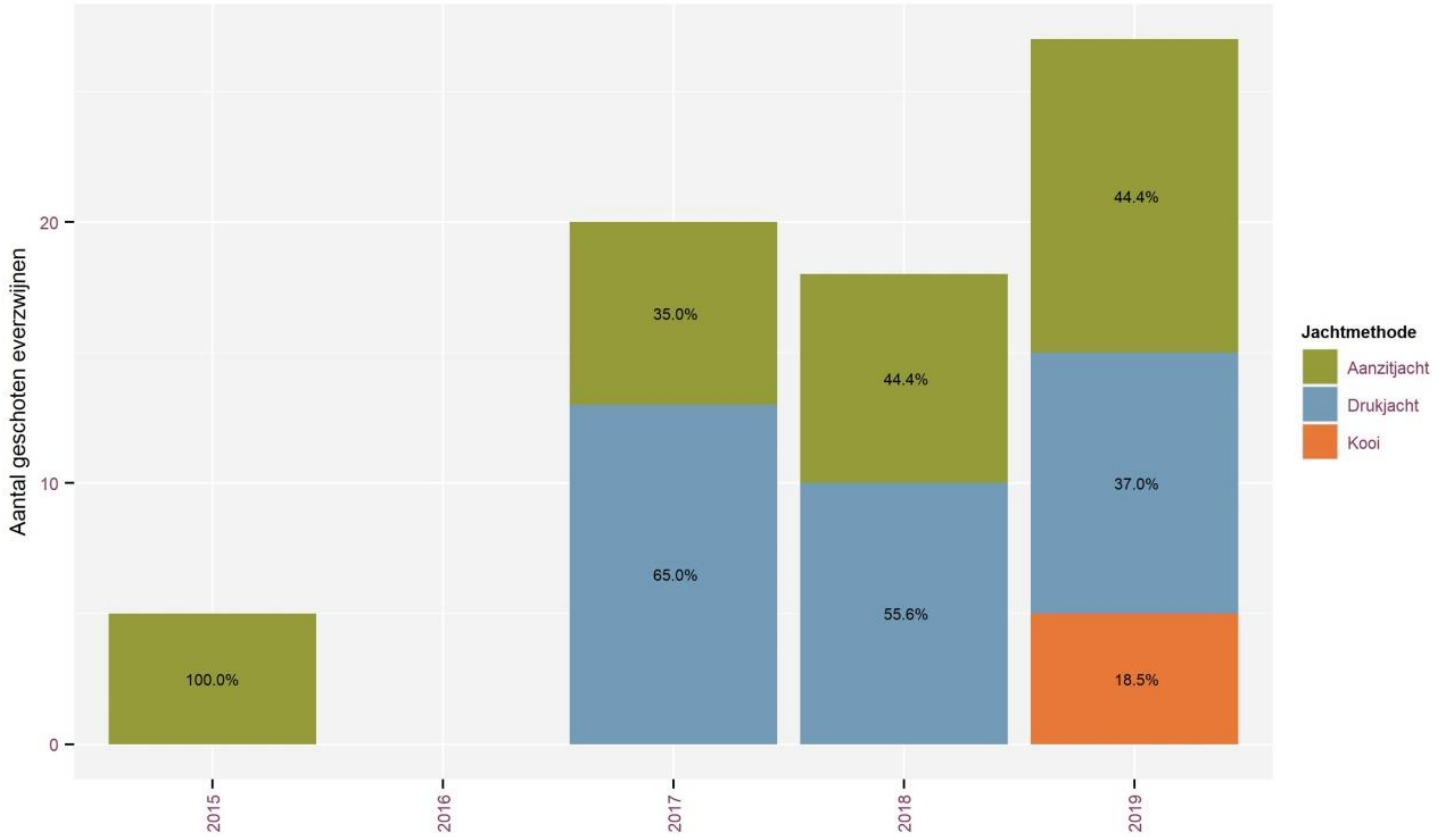




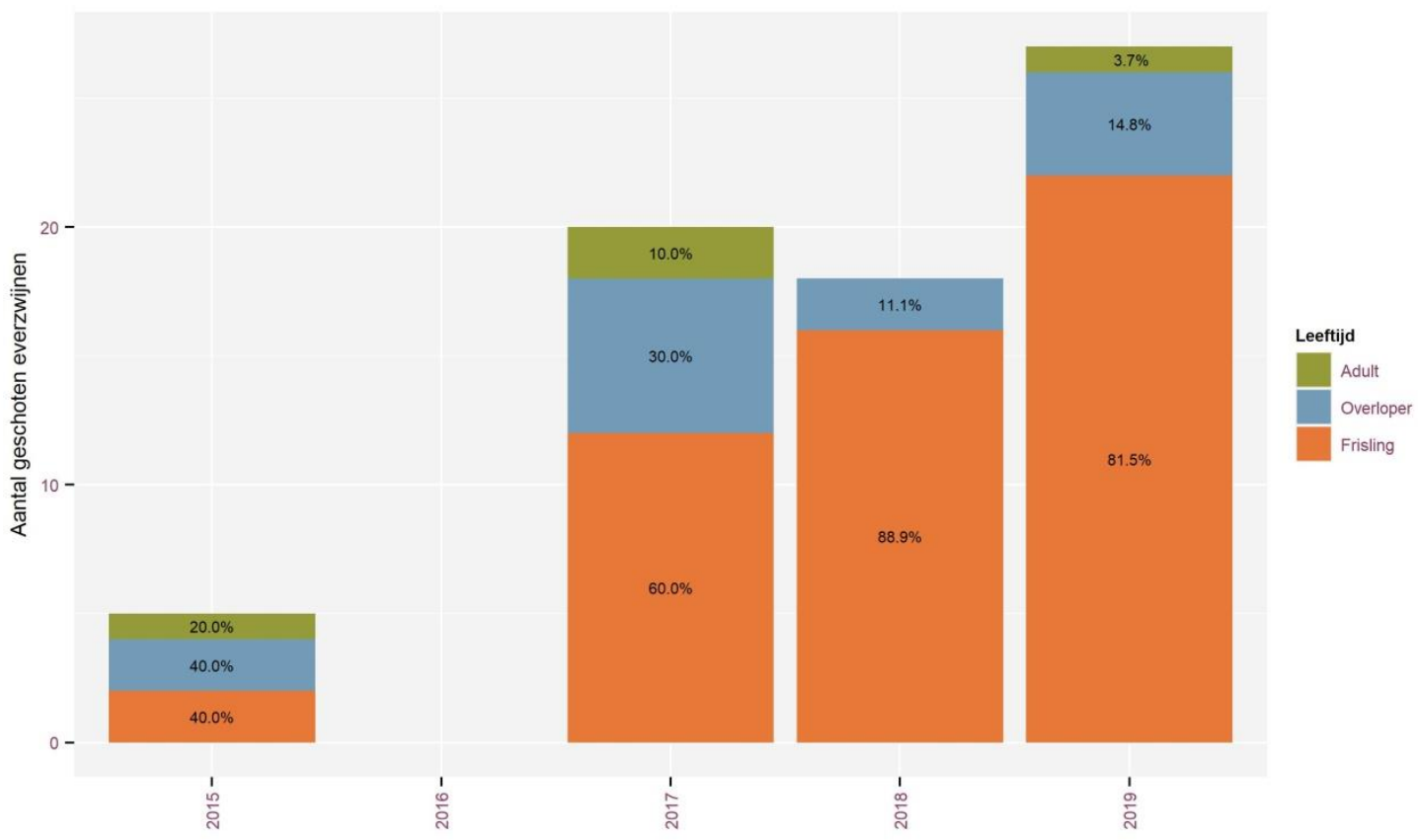

Figuur 34: Afschot van everzwijnen in het projectgebied, opgedeeld naar jachtmethodes (a) en leeftijdscategorie (b)

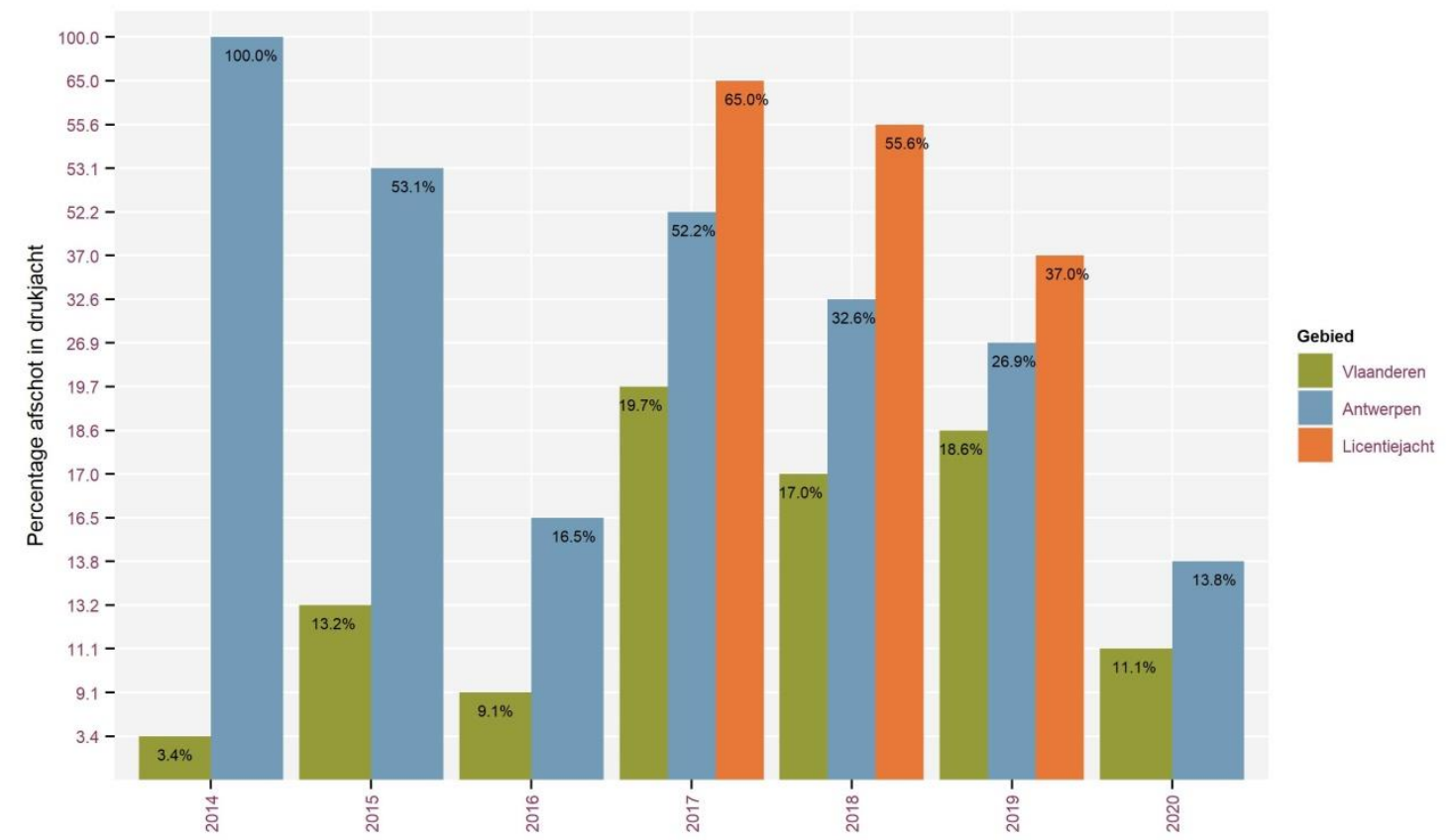

Figuur 35: Percentage afschot dat via drukjacht werd gerealiseerd in Vlaanderen, in de provincie Antwerpen en in het projectgebied in de periode $2014-2020$ 


\section{EVALUATIE VAN DE SOCIO-ECONOMISCHE ASPECTEN}

\subsection{INLEIDINING}

Een degelijke onderbouwde keuze en vergelijking van de voor- en nadelen van een bepaalde beheerstrategie of -methode, in deze het instrument van licentiejacht, is maar mogelijk door alle verschillende invalshoeken en doelstellingen in de evaluatie mee te nemen. Het vergelijken en afwegen van mogelijke opties vergt dat de verschillende nagestreefde doelstellingen gekend zijn (Gregory et al., 2012; Hammond et al., 2002; Runge et al., 2013). In het kader van het uittesten van licentiejacht als beheerinstrument wil dit zeggen dat er niet alleen gekeken moet worden naar de mate waarin het nagestreefde populatiebeheer van ree effectief gerealiseerd kan worden, maar ook naar de finaliteit van het populatiebeheer, namelijk de verjonging van loofboomdoelsoorten en de andere doelstellingen (zie hoofdstuk 3). De mate waarin de ene doelstelling zwaarder doorweegt dan de andere bij de keuze voor een bepaalde aanpak/beheermaatregel, is een waardekeuze voor de beheerder of van beleidsmakers(Casaer and Huysentruyt, 2017).

Een van de terugkerende doelstellingen (zie hoofdstuk 3 ) is het minimaliseren van de kosten van het wildbeheer, zowel voor de overheid als voor de licentiehouders. Een andere doelstelling, en algemene voorwaarde voor een duurzaam wildbeheer, is dat er voldoende maatschappelijk draagvlak is voor het gevoerde beheer. Dit vereist dat de gekozen maatregelen en de manier waarop ze toegepast worden, op voldoende steun kunnen rekenen bij het brede publiek en bij de stakeholders die rechtstreeks impact ondervinden van de beheermaatregelen of instaan voor de implementatie ervan. In het geval van de licentiejacht gaat dit over het brede publiek, mogelijke andere bosgebruikers (recreanten, houtexploitanten), het betrokken ANB-personeel, de licentiehouders zelf alsook de jachtsector.

\subsection{ECONOMISCHE ASPECTEN: INKOMSTEN EN KOSTEN}

\subsubsection{Inleiding}

Voor het analyseren van de economische aspecten van een vorm van jacht, dienen de verschillende invalshoeken van de verschillende betrokken partijen mee in rekening genomen te worden. In dit hoofdstuk willen we vooral de beschikbare data op een geobjectiveerde manier weergeven om zo vergelijkingen met andere bronnen of toekomstige ervaringen mogelijk te maken.

Objectiveerbare economische gegevens zijn de inkomsten (de prijs die de jager betaalt om te mogen jagen en de prijs per geschoten dier) en de kosten (bv. wildbescherming, investeringen in jachtinfrastructuur zoals hoogzitten en de kost van werkuren) voor de verpachter.

Bij het licentiejachtproject werden de licenties jaarlijks toegekend aan de hoogste bieders. Het aantal licenties is doorheen het project voor zowel Arendonk als Ravels toegenomen en dit zowel voor de winterperiode als voor de zomerperiode. Vanaf 2013 werd er een minimumbod van $€ 150$ opgenomen in de verpachtingsvoorwaarden. 


\subsubsection{Inkomsten uit licentiejacht voor de verpachtende overheid}

De inkomsten voor de overheid bestonden uit licenties die betaald werden en uit het bedrag betaald per geschoten stuk wild. In de verpachtingsvoorwaarden was aangegeven dat alle stukken door de licentiehouder gekocht moesten worden met een vooraf bepaalde prijs per $\mathrm{kg}$. Dit bedrag werd vastgelegd op $€ 4$ per $\mathrm{kg}$ leeggewicht voor reewild, $€ 1,5$ per $\mathrm{kg}$ voor everzwijnen onder de $50 \mathrm{~kg}$ en $€ 1$ per $\mathrm{kg}$ voor everzwijnen van meer dan $50 \mathrm{~kg}$ leeggewicht.

De licenties waren ongeveer goed voor 65 à $80 \%$ van de inkomsten. We zien dat de inkomsten uit wildbraad van ree vrij constant blijven doorheen de duur van het project (Figuur 36). De inkomsten van wildbraad van everzwijnen werden niet mee opgenomen in de grafiek.

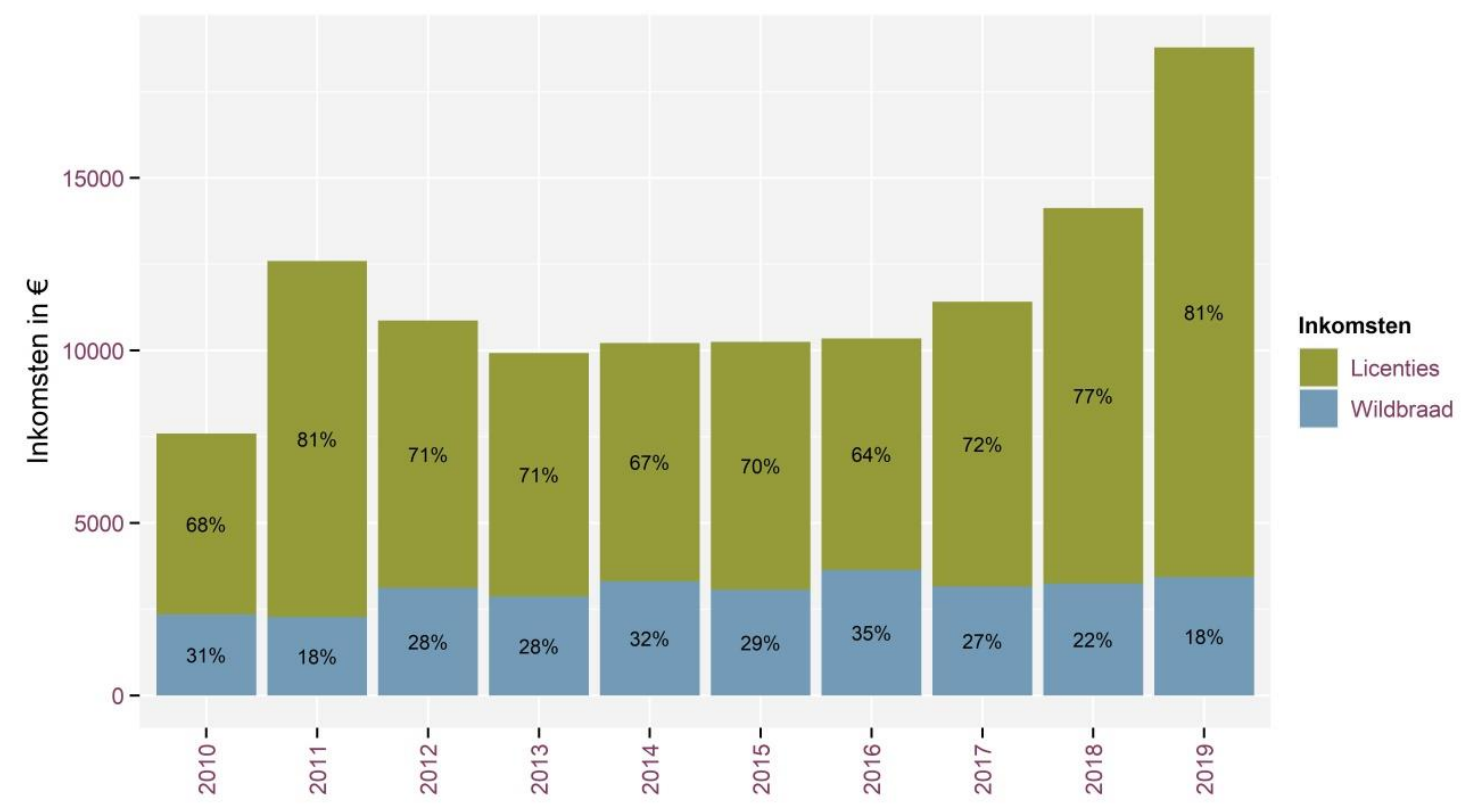

Figuur 36: Inkomsten uit de licentiejacht. Het percentage geeft het deel van de inkomsten weer dat respectievelijk door de licenties, dan wel door de verkoop van wildbraad gegenereerd werd. Voor wildbraad worden hier enkel de inkomsten van reewild meegenomen

De stijging van inkomsten na 2015 is het gevolg van de hogere bedragen die geboden werden voor een licentie. Dit blijkt ook uit het gemiddeld bedrag dat jaarlijks voor een licentie betaald werd (Figuur 37): Nadat de prijs per licentie daalde tussen 2011 en 2015, steeg deze vervolgens weer. Mogelijk speelt de aanwezigheid van everzwijn hier een rol. Ravels lijkt niet systematisch duurder dan Arendonk en ook lijkt geen van beide seizoenen systematisch tot een hogere prijs geleid te hebben. Dat hier zeker ergens het effect van vraag en aanbod speelt, blijkt ook uit de verhouding tussen het aantal beschikbare licenties en het aantal biedingen per seizoen (Figuur 38). 


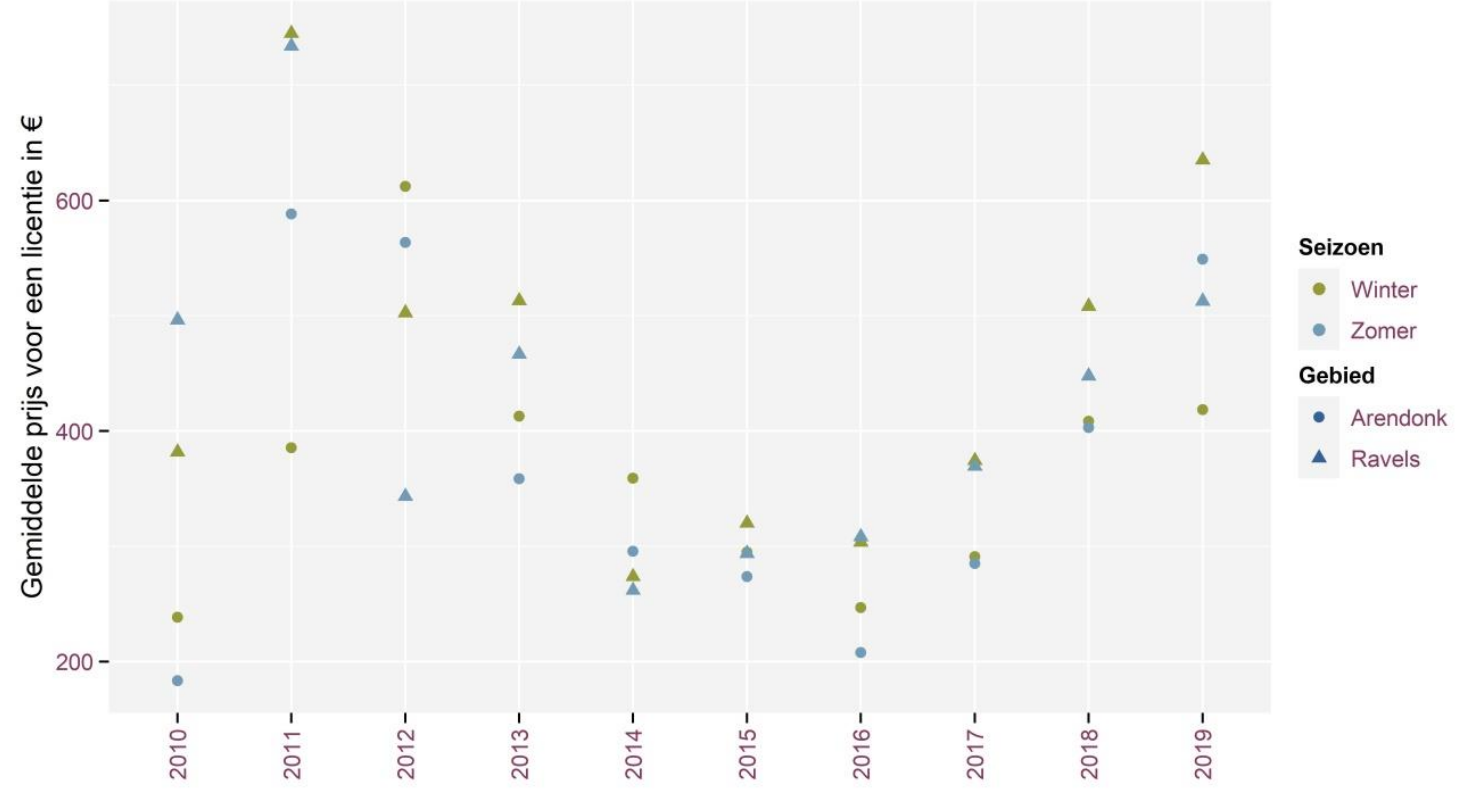

Figuur 37: Gemiddelde prijs per licentie die door een deelnemende jager betaald werd. Groen staat voor de wintermaanden, blauw voor de zomermaanden. De driehoekjes geven de gemiddelde pacht voor Ravels weer, de bolletjes voor Arendonk

Net voor het beëindigen van de jacht in Arendonk in 2001, bedroeg de totale pachtprijs $\pm €$ 17.000. De totale inkomsten van de licentiejacht lijken dus lager te liggen dan bij de vorige verpachting. Hierbij zijn de kosten niet in rekening gebracht.

Om vergelijkingen mogelijk te maken met andere gebieden, berekenden we voor de licentiejacht de prijs per hectare: de pachtinkomsten per 100 ha startten aan $€ 566$ per 100 ha in het eerste jaar. Daarna situeerden de inkomsten per 100 ha zich een aantal jaren tussen $€$ 700 en $€ 800$. Na 2016 stegen de inkomsten per 100 ha tot $€ 1435$ in 2019. Vergelijken we de betaalde pacht per 100 ha met deze van 16 andere gebieden van ANB, valt op dat er voor deze andere gebieden een heel grote spreiding is: van $€ 300$ tot meer dan $€ 10000$ per 100 ha of minder dan $€ 10$ per ha tot meer dan $€ 100$ per ha. Hoewel de dataset van de andere gebieden beperkt is, situeert het gemiddelde zich binnen die dataset rond $€ 2000$ per 100 ha en de mediaan rond $€ 1000$ per 100 ha. Het grote verschil tussen deze twee waarden is het gevolg van enkele gebieden met zeer hoge pachtprijzen per 100 ha. Ten opzichte van deze beperkte steekproef situeert de licentiejacht zich dus ergens tussen het gemiddelde en de mediaan.

Ter vergelijking: de 46 licenties van de licentiejacht in het Forêt D'Anlier in Wallonië brachten in 2017 samen $€ 30.500$ op of om en bij de $€ 665$ per licentie. Daarnaast leverde deze jachtverpachting nog $€ 15911$ op door de verkoop van wild. De inkomsten voor deze twee posten samen - op een verpachte oppervlakte van 1406 ha - bedroegen dus $€ 3300$ per 100 ha. Deze hogere inkomsten kunnen deels te verklaren zijn door de aanwezigheid van edelhert waarop via enkele licenties gejaagd kon worden.

\subsubsection{Kosten van licentiejacht voor de verpachtende overheid}

Aan de organisatie van de jacht zijn ook kosten verbonden. Het gaat hierbij over investeringen in infrastructuur op het terrein (hoogzitten), materiaal om te ontweiden en de inzet van personeel bij de voorbereiding en bij de uitoefening van de jacht. Voor het plaatsen van de hoogzitten op het terrein is zowel voorbereidend werk nodig (prospectie) als een jaarlijkse controle en eventueel ook het vrijmaken van de vegetatie voor de hoogzit om een goed zicht te garanderen en zo de kansen tot veilig afschot te vergroten. Hoewel in de loop van het IIIIIIIIIIIIIIIIIIIIIIIIIIIIIIIIIIIIIIIIIIIIIIIIIIIIIIIIIIIIIIIIIIIIIIIIIIIIIIIIIIIIIIIIIIIIIIIIIIIIIIIIIIIIIIIIIIIIIII 
project geen gedetailleerde gegevens hierover verzameld werden, staat wel vast dat aan het verpachten van de jacht via licenties inherent een aantal kosten verbonden zijn voor de overheid/terreinbeheerder die bij een klassieke verpachting niet voorkomen (vb. aankoop van hoogzitten)

\subsubsection{Kosten voor de deelnemende jagers aan licentiejacht}

De directe kosten voor de licentiehouder bestaan uit het betalen van de geboden prijs voor de licentie, een administratieve kost ( $10 \%$ van het bod) en de aankoopprijs voor het geschoten wildbraad. Kosten voor uitrusting, kleding of andere kosten verbonden aan het uitoefenen van de jacht werden hier niet mee opgenomen. Er is tijdens de eerste twee jaren een grote spreiding in de geboden bedragen (Figuur 39). De stijging sinds 2016 valt - al dan niet toevallig - samen met de terugkeer van everzwijn en de mogelijkheid om als licentiehouder everzwijn te bejagen gedurende de licentiejacht en ook deel te nemen aan drukjachten als die georganiseerd worden (Figuur 38).

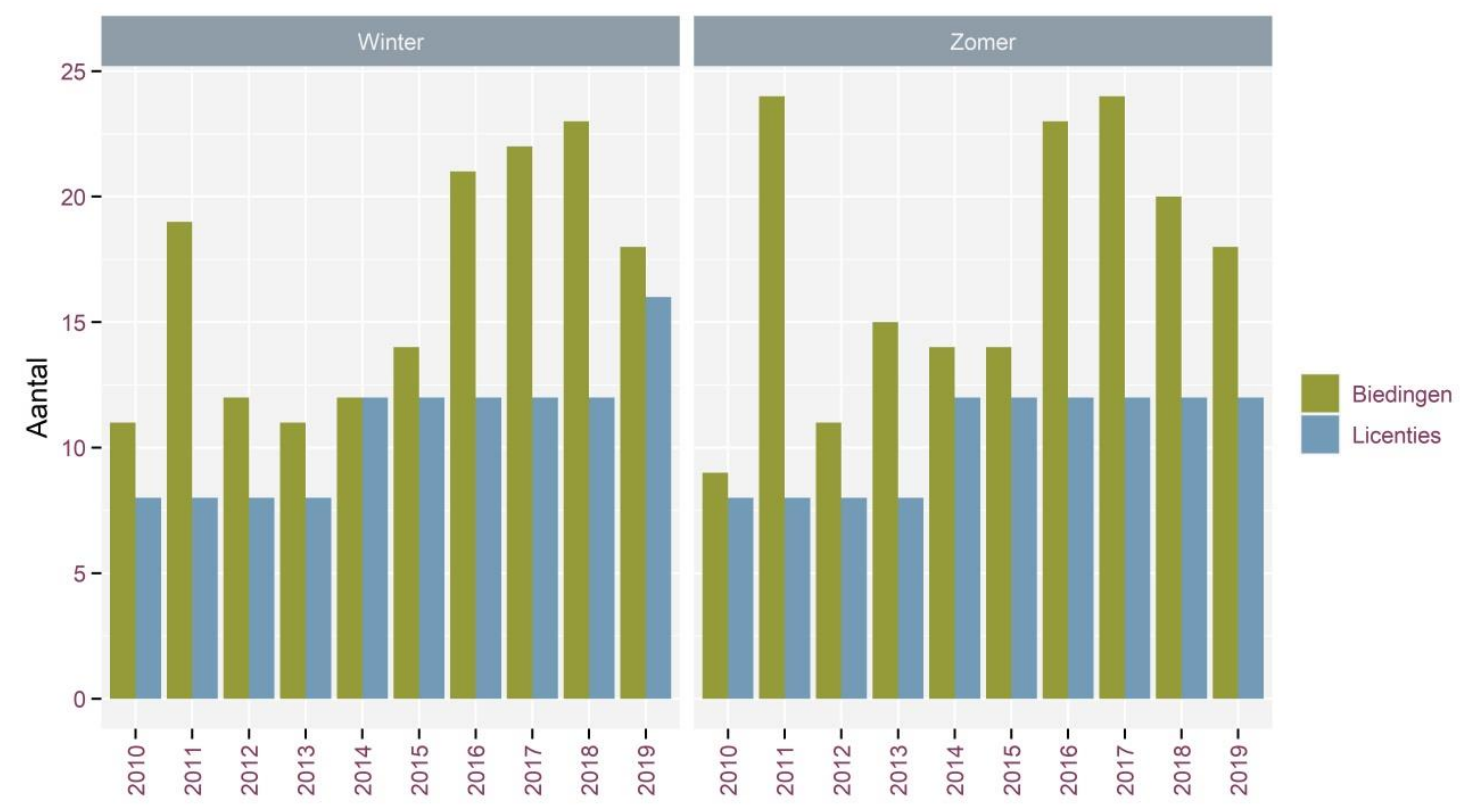

Figuur 38: Het aantal beschikbare licenties voor Ravels en Arendonk, en het aantal biedingen per seizoen en per jaar 


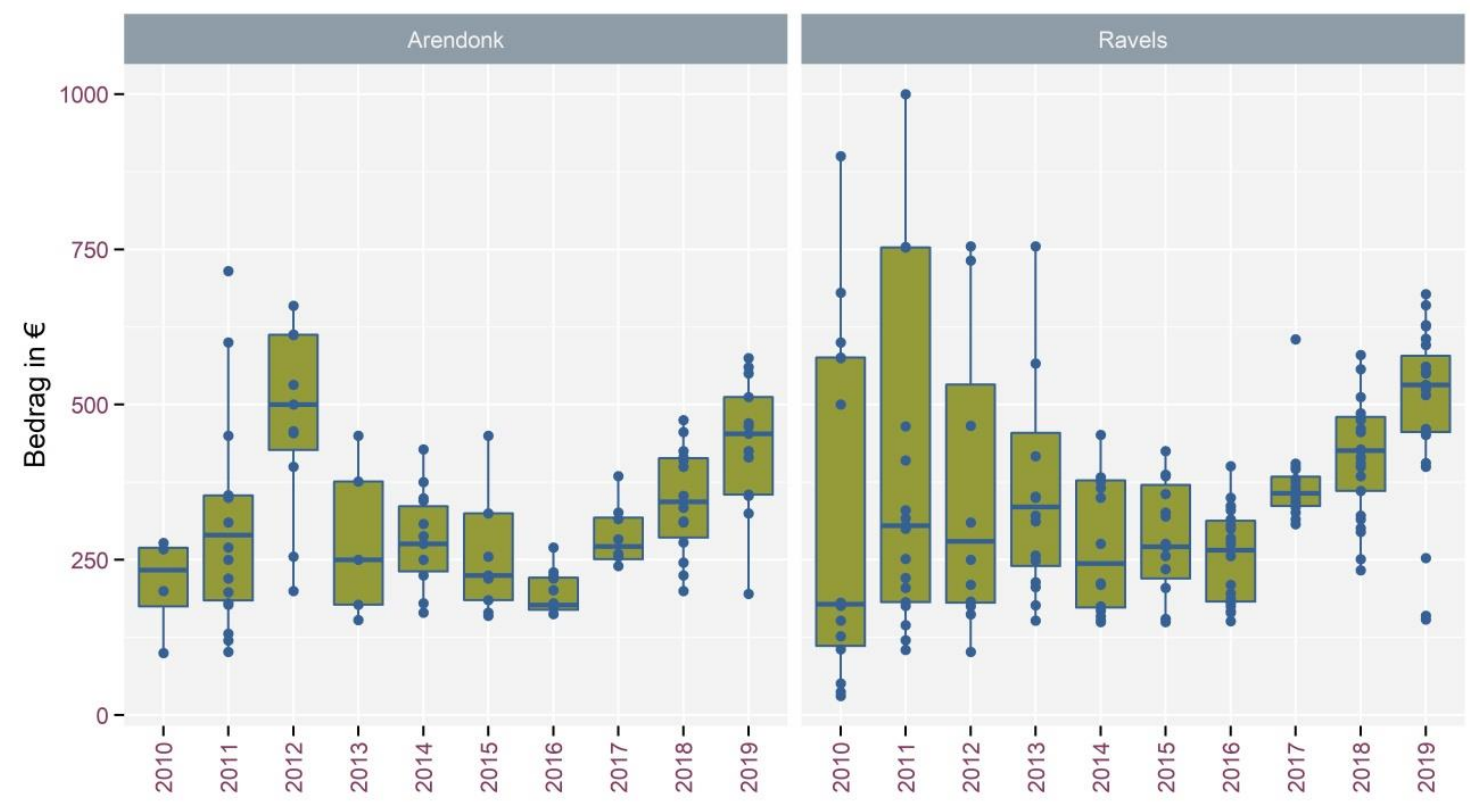

Figuur 39: Bedragen geboden voor een licentie in Ravels en Arendonk gedurende het proefproject. Voor 2013, 2016 en 2017 zijn enkel de weerhouden hoogste biedingen gekend. Mogelijk zijn er dus nog lagere biedingen geweest die niet opgenomen zijn in de figuur

\subsection{BEVRAGING VAN LICENTIEHOUDERS}

\subsubsection{Inleiding}

Om een zicht te krijgen op de ervaringen van de licentiehouders, werd een online enquête opgesteld. De enquête werd verstuurd naar alle licentiehouders met een gekend e-mailadres (49 personen van 54 deelnemers) in april 2020. In de enquête werd gepeild naar de achtergrond van de licentiehouder alsook over de jachtervaring buiten en tijdens het licentiejachtproject. Op die manier werd een profiel verkregen van de deelnemers aan het proefproject (subthema 1 van de enquête). Daarnaast werden ze bevraagd over hun verwachtingen, ervaringen en meningen m.b.t. de licentiejachtdoelstellingen (subthema 2) en het gebruik van jachtdagboekjes (subthema 3 ) (De volledige vragenlijst is terug te vinden in bijlage 3).

In totaal werden 43 volledig ingevulde vragenlijsten ontvangen wat resulteerde in een antwoordpercentage van $88 \%$. Per thema werden de antwoorden geanalyseerd. Voor het grootste deel van de vragen werd de verdeling van de antwoorden over de verschillende antwoordmogelijkheden berekend en gevisualiseerd aan de hand van staafdiagrammen. Voor enkele vragen (de mate van akkoord gaan met uitspraken over licentiejacht en de mate van het belang dat verschillende aspecten van het toepassen van licenties hebben voor de deelnemers) werden figuren gemaakt die Potential for Conflict Indices (PCI) weergeven (Vaske et al., 2010; Vaske et al., 2006). Deze grafische voorstelling van PCl-waardes laat toe om voor de antwoorden op een bepaald vraag tegelijkertijd de gemiddelde mening weer te geven (positie van de bubbel) als de mate van eensgezindheid of verschillen in mening tussen de personen die antwoordden: grote bubbels duiden op een grote variatie in meningen terwijl kleine bubbels duiden op eensgezindheid over een bepaalde vraag (zie Figuur 50 \& Figuur 51). Deze mate waarin meningen verdeeld zijn, wordt ook aangeduid door de $\mathrm{PCl}$-waarde dewelke varieert tussen 0 (helemaal geen meningsverschillen) en 1 (opvattingen liggen totaal uit elkaar) 


\subsubsection{Subthema 1: profiel van licentiehouders}

Aan de hand van de gestelde achtergrondvragen werd een duidelijk beeld verkregen van het profiel van de deelnemende jagers. De leeftijdscategorie 40- tot 60-jarigen is het best vertegenwoordigd (53,5\% van de respondenten), jongere jagers zijn minder vertegenwoordigd $(18,6 \%), 27,9 \%$ van de licentiehouders zijn ouder dan 60 jaar (Figuur 40a). Daarnaast is er een grote variatie te zien in de afstand van de woonplaats van de licentiehouders tot het licentiejachtgebieden. De afstand gaat van 0-5 km (18,6\%) tot meer dan $40 \mathrm{~km}(32,6 \%)$ (Figuur 40b). Buiten de licentiejacht jagen de meeste personen zowel op grofwild als op kleinwild en overig wild (69,8\%). Slechts 4,7\% jaagt buiten de licentiejacht niet op grofwild (Figuur 40c).

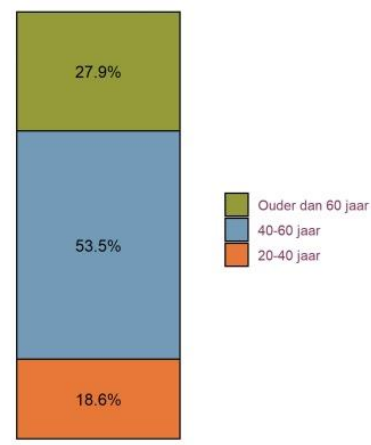

b

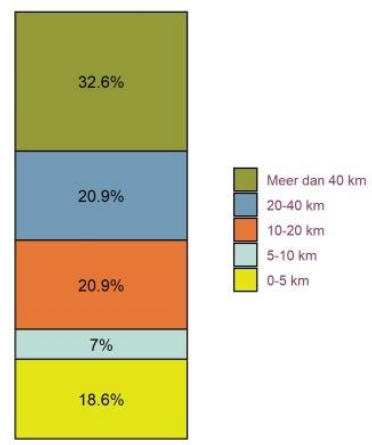

c

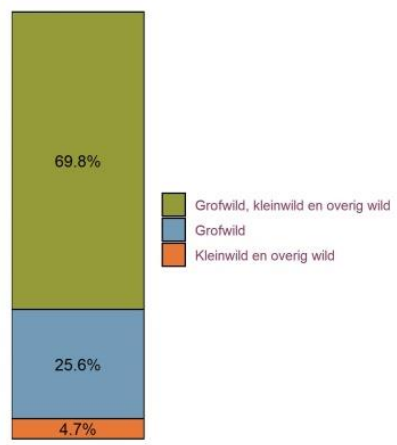

Figuur 40: De achtergrond van de licentiehouders: leeftijd van de licentiehouders (a), afstand van de woonplaats van de licentiehouder tot de licentiejachtgebieden (b) en door de licentiehouders bejaagde soorten buiten het licentiejachtproject

Op basis van het aantal jachtverloven van de licentiejachthouders - als maat voor het aantal jaren ervaring de deelnemers hadden als jagers (Figuur 41), varieert de ervaring van beginnende jager ( 2 jachtverloven in Vlaanderen) tot jagers met jarenlange ervaring (61 jachtverloven in Vlaanderen en/of Wallonië). Hierbij dient wel aangegeven te worden dat het aantal jachtverloven op zich enkel een richtinggevende maat is. Het aantal keer dat een jager tijdens een jaar jaagt, kan hier niet uit worden afgeleid. Tussen personen met een gelijk aantal jachtverloven kunnen dus nog grote verschillen in jachtervaring bestaan. 


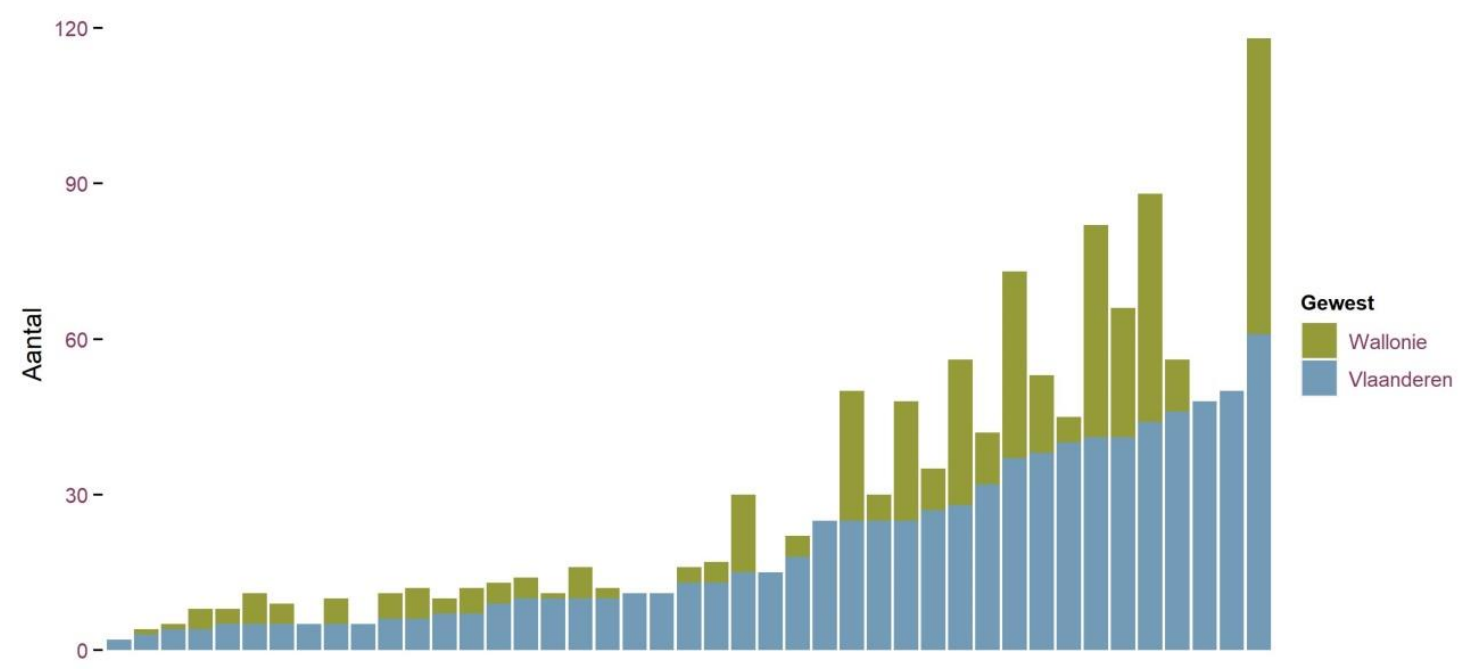

Respondenten

Figuur 41: Het aantal jachtverloven van de licentiehouders in Vlaanderen en Wallonië

Het grootste deel van de licentiehouders $(78,6 \%)$ had geen ervaring had met jacht onder licenties in het buitenland (Figuur 42). De meeste jagers hebben wel al deel genomen aan jachtdagen op terreinen waar ze zelf geen jachtrechthouder of medejachtrechthouder zijn (bijvoorbeeld als genodigde of gedurende een jachtreis) in Wallonië $(54,8 \%)$ of in het buitenland (76,2\%). 56\% van de respondenten geeft aan medejachtrechthouder en $28 \%$ hoofdjachtrechthouder te zijn van jachtterreinen in België, $7 \%$ is terreineigenaar. $26 \%$ is momenteel licentiehouder ergens anders in België. $56 \%$ van de respondenten heeft als genodigde in België gejaagd (Figuur 43).
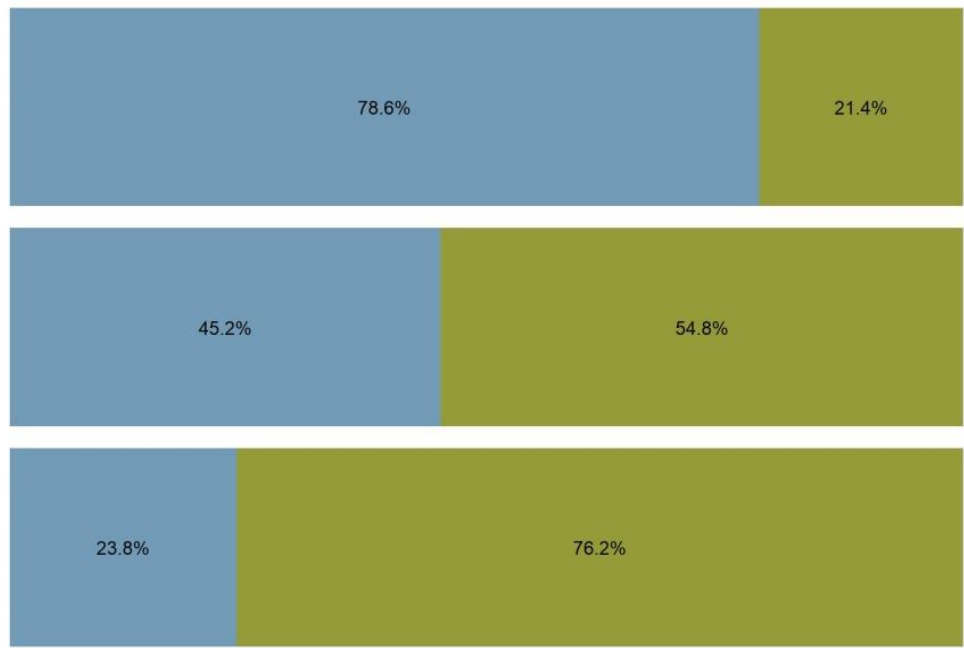

Figuur 42: De ervaring van de respondenten met licentiejachtprojecten in het buitenland alsook hun deelname aan jachtdagen buiten Vlaanderen op terreinen waar men geen jachtrechthouder of medejachtrechthouder is (bijvoorbeeld als genodigde of gedurende een jachtreis) 


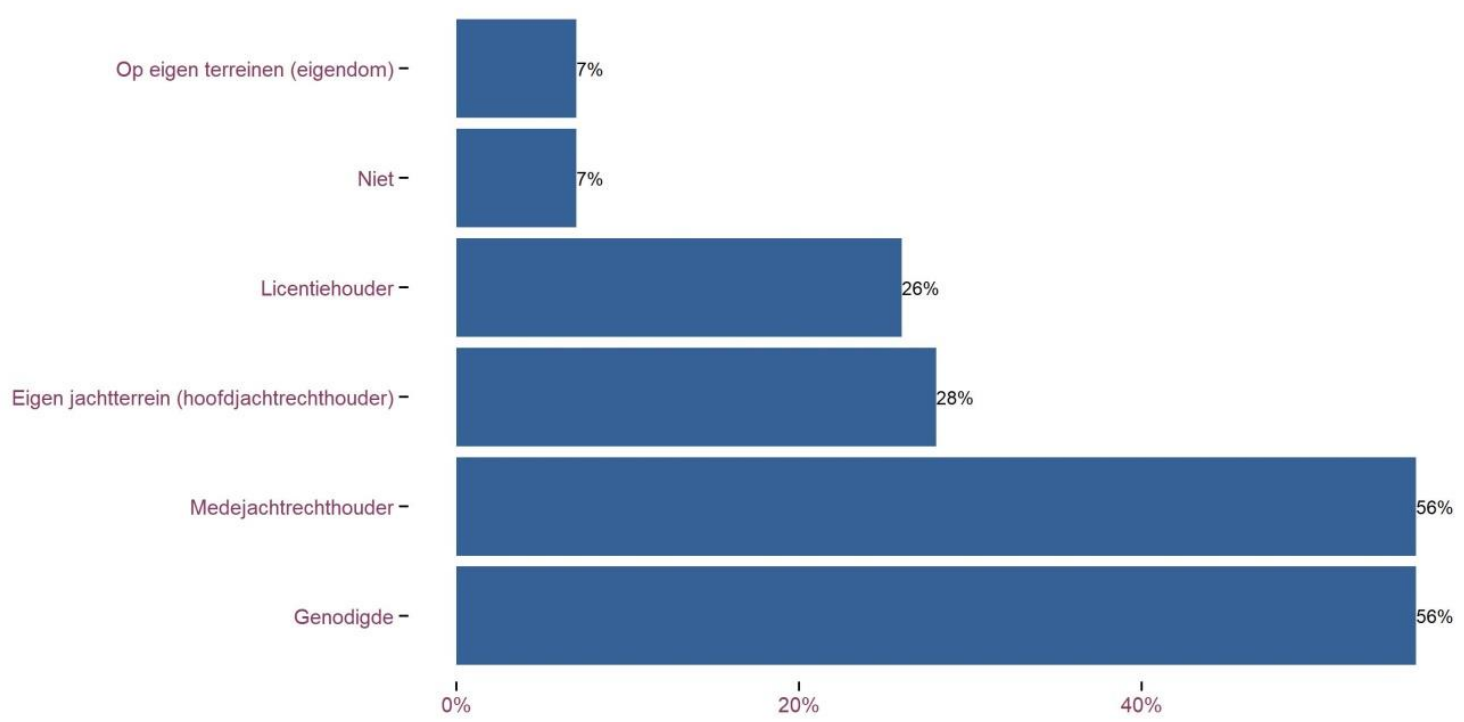

Figuur 43: De verdeling van de verschillende hoedanigheden van jacht waaraan de respondenten in België deelnemen

Figuur 44 illustreert op welke manier de licentiehouders kennismaakten met het licentiejachtproject: het grootste deel (53\%) hoorde over het project via mond-aan-mond reclame van collega-jagers. Anderen vonden de weg via de Vlaamse Jager (15\%), de nieuwsbrief Hunting (7\%) of via het ANB (21\%).

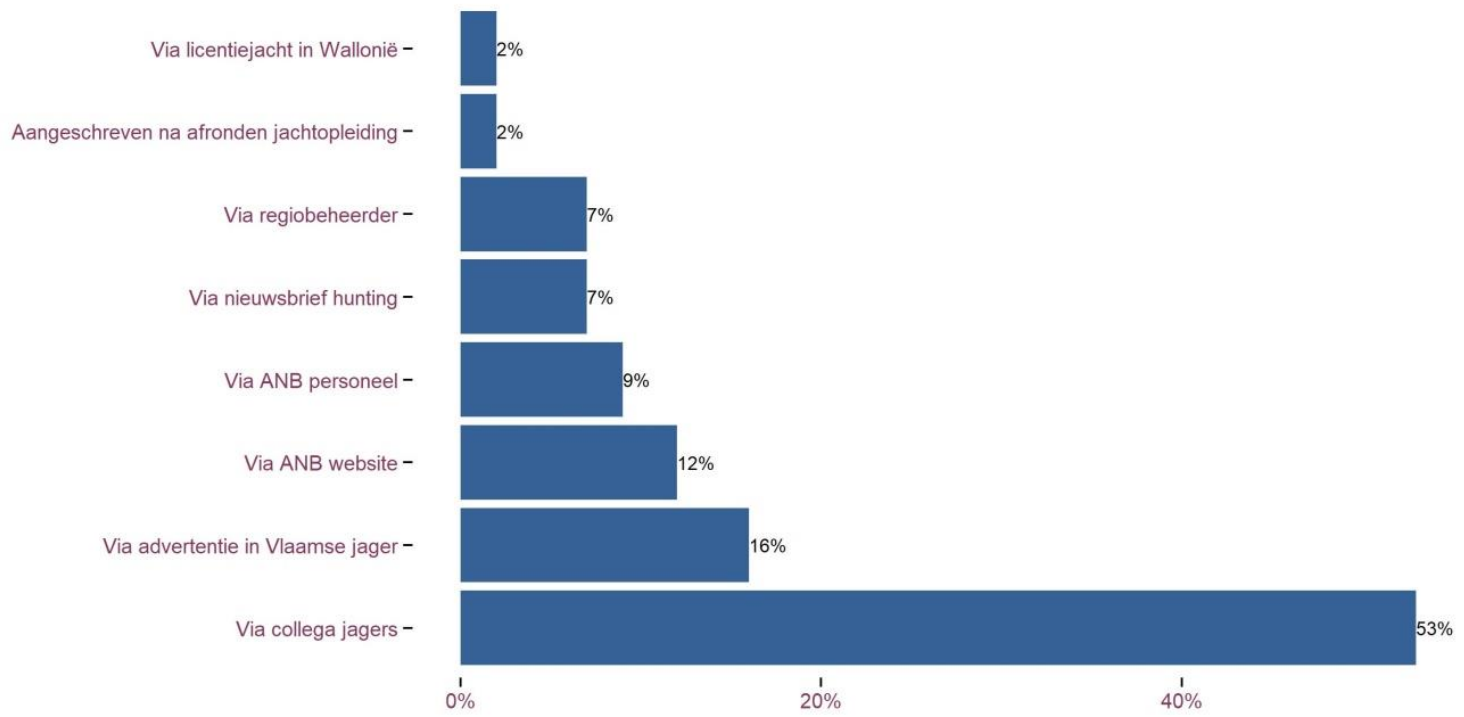

Figuur 44: Weergave van hoe de licentiehouders kennismaakten met het licentiejachtproject

\subsubsection{Subthema 2: ervaringen, verwachtingen en meningen}

Kijkend naar de ervaring van de licentiehouders binnen het licentiejachtproject (Figuur 45), is een grote variatie te zien in het aantal keren dat een licentiehouder doorheen de jaren deelnam aan het proefproject. Sommigen namen slechts één enkele keer deel, het maximum lag op 22 licenties. Bepaalde licentiehouders hebben altijd in hetzelfde gebied licenties verkregen, terwijl anderen in zowel Ravels als Arendonk en zowel in de zomer als in de winter deelnamen. 


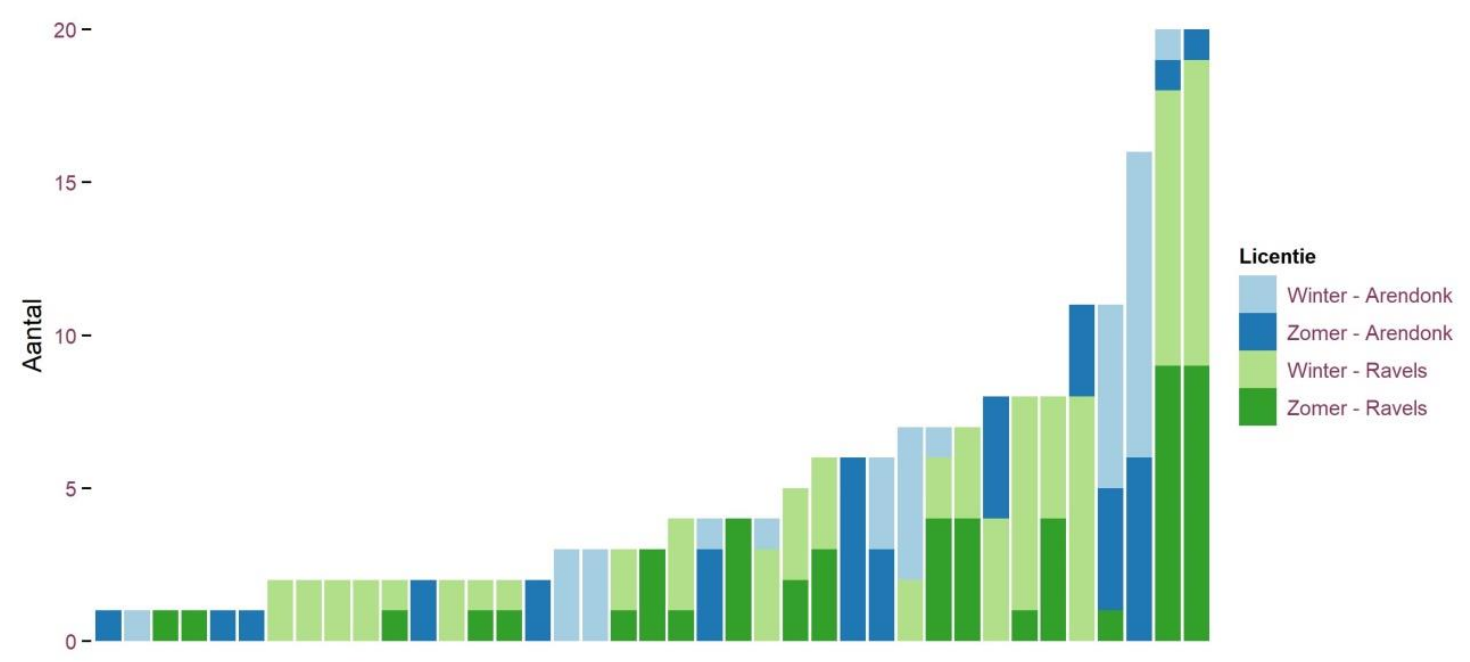

Respondenten

Figuur 45: De verdeling van het aantal verkregen licenties bij de verschillende respondenten over de gehele duur van het licentiejachtproject

Het grootste deel van de licentiehouders geeft aan dat ze de deelname positief (57\%) tot heel positief (21\%) ervaren hebben. Slechts $5 \%$ heeft het project als negatief ervaren en niemand als heel negatief (Figuur 46a). Een groot aandeel van de licentiehouders (38\%) staat neutraal tegenover het feit dat beslissingen en acties (zoals de omvang van het afschot en de plaatsing van de hoogzitten) niet door de licentiehouder zelf, maar door de terreinbeheerder wordt genomen (Figuur 46b). Een grote meerderheid staat hier eerder positief tegenover (33\% ervaart dit als positief en $12 \%$ als heel positief). $16 \%$ van de licentiehouders heeft hier wel een probleem mee en geeft aan hier negatief (14\%) of heel negatief $(2 \%)$ tegenover te staan.

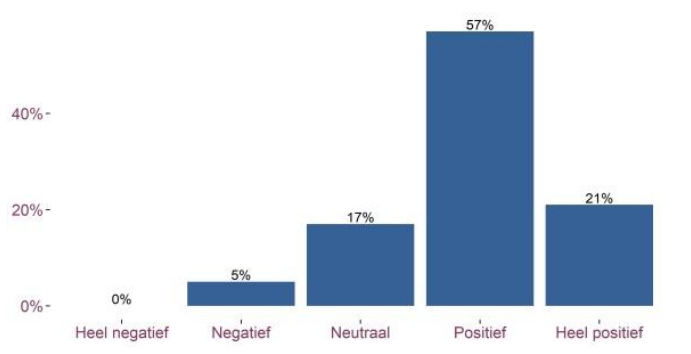

b

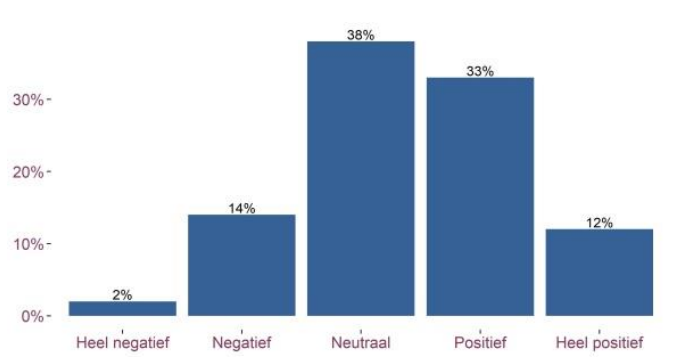

Figuur 46: Perceptie van de respondenten van hun deelname aan het licentiejachtproject (a). De verdeling van hoe licentiehouders staan tegenover het feit dat beslissingen en acties (zoals de omvang van het afschot en de plaatsing van de hoogzitten) niet door de licentiehouder maar door de terreinbeheerder wordt genomen (b)

Een vraag die doorheen de jaren verschillende keren aan bod kwam, is de communicatie en informatiedoorstroming tussen de overheid als terreinbeheerder en de licentiehouders. Figuur 47 illustreert dat het grootste aandeel van de respondenten $(78,6 \%)$ zegt zicht te hebben op de motieven van de terreinbeheerder achter de genomen beslissingen en $50 \%$ heeft ervaren dat er inspraak mogelijk is op de organisatie van de licentiejacht. $82,5 \%$ denkt dat licentiejacht ook mogelijk is in andere gebieden en $83,3 \%$ zou licentiejacht aanraden aan andere jagers. $81 \%$ van de respondenten zou in de toekomst opnieuw deelnemen aan licentiejacht. Op basis van deze cijfers kunnen we besluiten dat de meeste deelnemers hun deelname aan het proefproject positief evalueerden. 

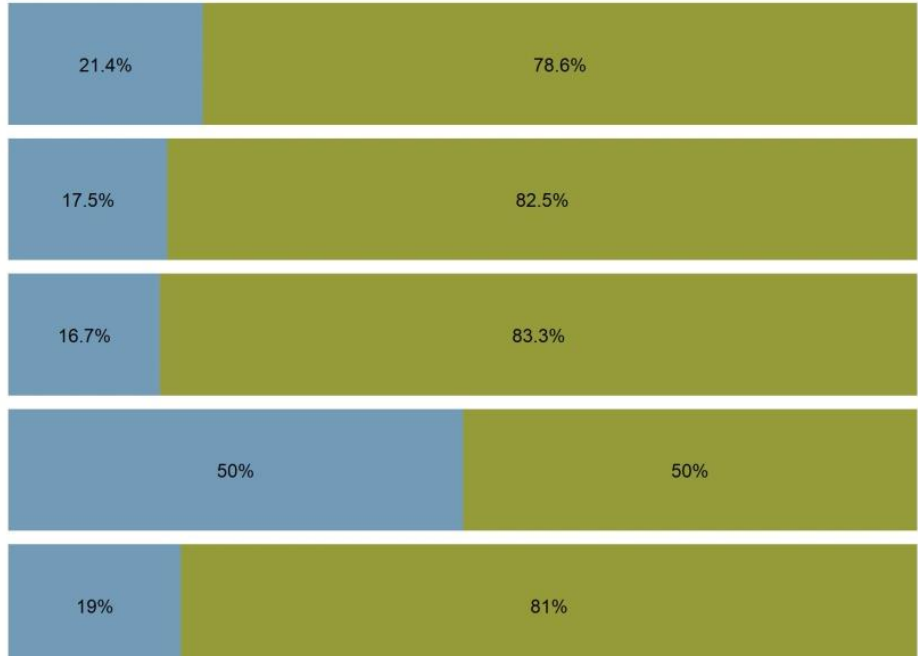

Figuur 47: De meningen van licentiehouders over het licentiejachtproject

Ook de perceptie over de samenwerking met de boswachters, met de regiobeheerder en tussen de licentiehouders (Figuur 48) werd over het algemeen goed (45\% t.o.v. regiobeheerder tot $67 \%$ t.o.v. medelicentiehouders) tot heel goed ( $40 \%$ t.o.v. boswachters en $48 \%$ t.o.v. regiobeheerder) ervaren. Slechts 1 persoon geeft aan een slechte ervaring opgelopen te hebben, en wel met de regiobeheerder.

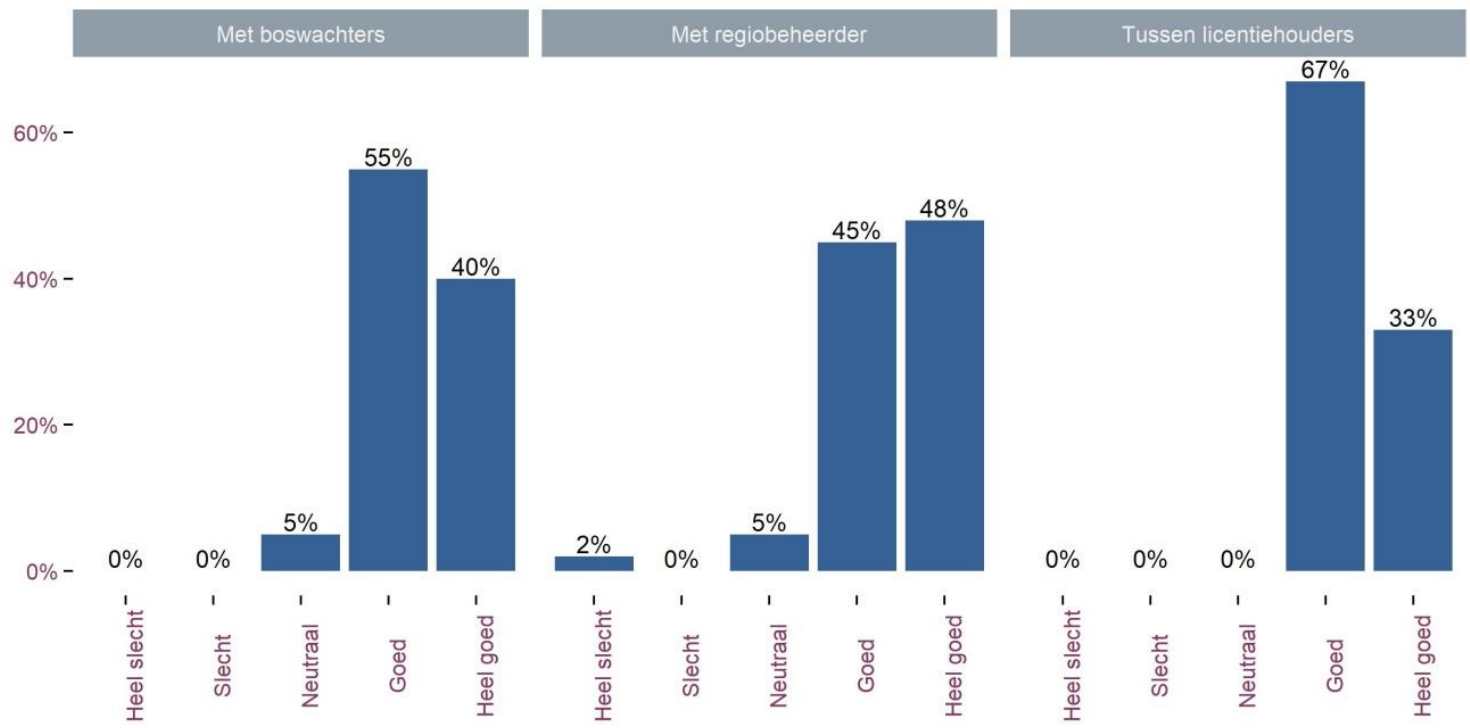

Figuur 48: Overzicht van hoe de samenwerking met boswachters, met regiobeheerder en tussen licentiehouders werd ervaren

Wanneer we de licentiehouders vragen wat zij vinden over de prijs van een licentie, dan zien we dat $10 \%$ van de respondenten de prijzen laag vindt, $29 \%$ vindt de prijzen hoog (Figuur 49). De overgrote meerderheid (62\%) staat neutraal tegenover de geboden bedragen. 


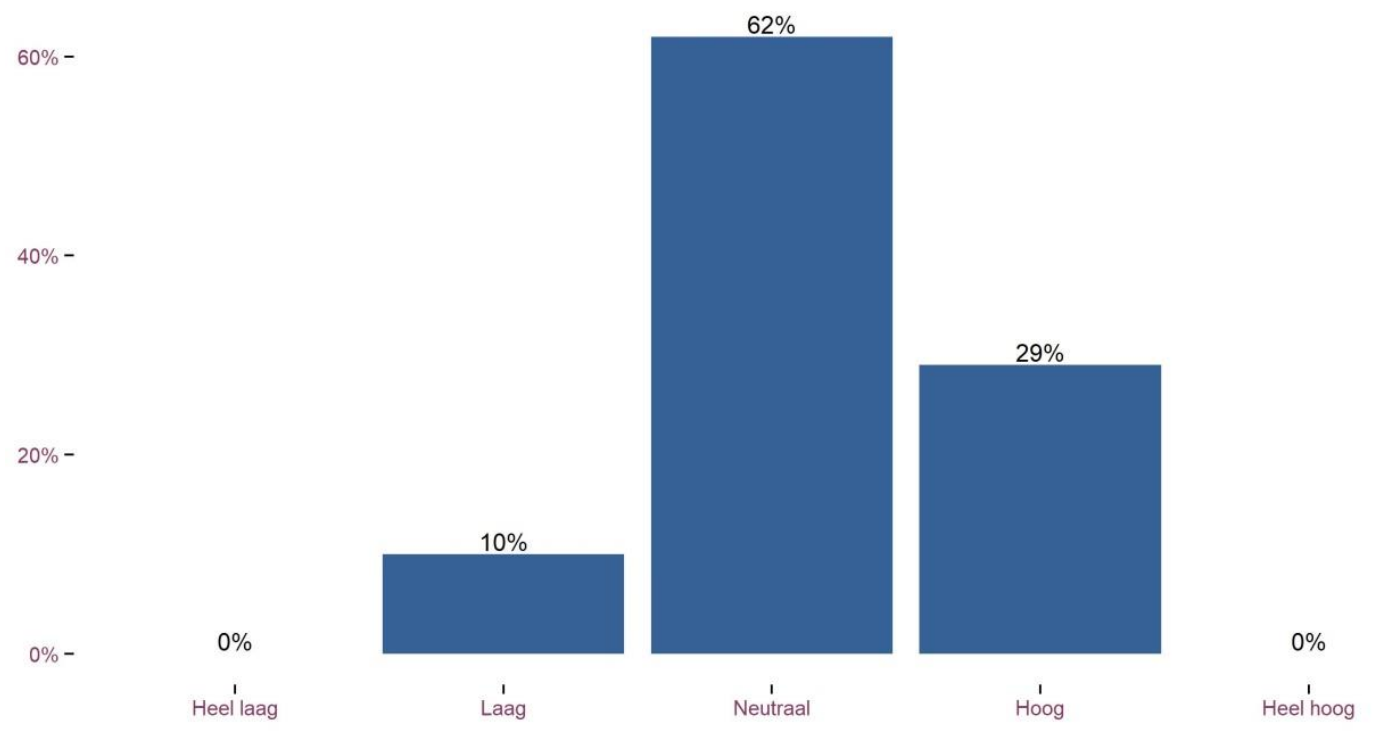

Figuur 49: Meningen over de prijs van een licentie tijdens het licentiejachtproject

De PCl-plot in Figuur 50 geeft aan in welke mate een bepaalde reden een belangrijk element vormde voor de jagers om deel te nemen als licentiehouder. Zoals hoger toegelicht wijzen kleine bollen erop dat de meeste deelnemers die mening delen, grote bollen dat er veel verschillen bestaan tussen de licentiehouders over een bepaald element.

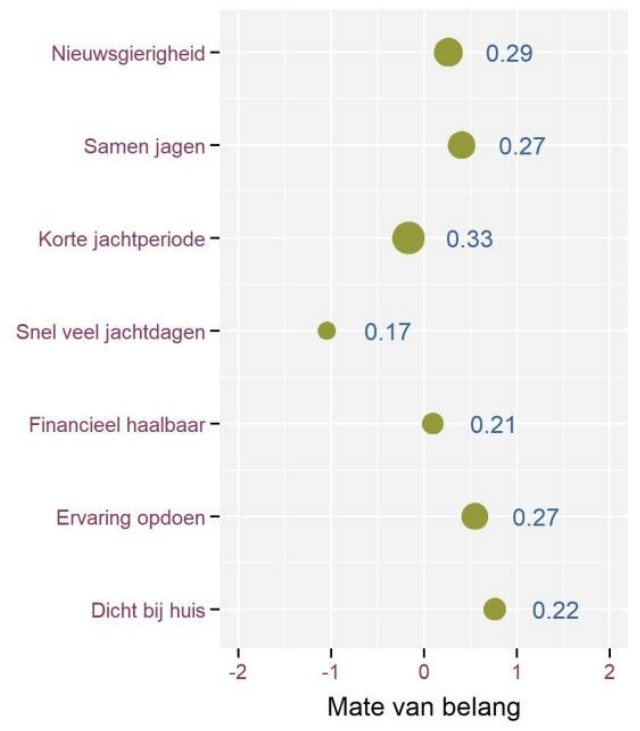

Figuur 50: PCl-plot dewelke beschrijft hoe belangrijk bepaalde redenen waren om mee te doen aan het licentiejachtproject. Respondenten konden deze redenen scoren van 'helemaal niet belangrijk' tot 'heel belangrijk'. Hoe groter de bubbel, hoe groter de variatie in meningen. Hoe kleiner de bubbel, hoe groter de eensgezindheid. Het getal geeft de $\mathrm{PCl}$-waarde weer. Deze varieert tussen 0 (helemaal geen meningsverschillen) en 1 (opvattingen liggen totaal uit elkaar)

Uit Figuur 50 blijkt dat het feit dat licentiejacht toelaat om gedurende een korte periode van het jaar veel jachtdagen te hebben zodat men de rest van het jaar met niet-jachtgerelateerde zaken bezig kan zijn (snel veel jachtdagen) weinig belang gehecht wordt (linkse ligging op de $x$ as, waarde van -1) en de meeste licentiehouders deze mening delen (kleine bubbel, $\mathrm{PCl}$ van $0,17)$. Het feit dat licentiejacht het mogelijk maakt om gedurende een korte periode van het 
jaar aan licentiejacht te doen en de rest van het jaar op een andere jacht actief te zijn, wordt beschouwd als een neutrale deelnamereden (centrale ligging op de $x$-as), hoewel er veel variatie is in mening van de respondenten (grote bubbel, $\mathrm{PCl}$ van 0,33 ). De mogelijkheid om dicht bij huis te kunnen jagen kreeg de hoogste score (belangrijkste argument) en werd door de meeste jagers zo ervaren (relatief kleine bubbel). Ook de mogelijkheid om ervaring op te doen als grofwildjager omdat licentiejacht goed omkaderd is, werd als vrij belangrijk beschouwd (rechtse ligging op de $x$-as), al is dit niet voor iedereen even belangrijk (grotere bubbel, $\mathrm{PCl}$ van 0,27). De nieuwsgierigheid om te zien hoe licentiejacht verloopt, de mogelijkheid om met andere jagers op een fijne manier samen te jagen en het feit dat licentiejacht financieel beter haalbaar is dan elders een jachtpacht te nemen, zijn neutrale tot belangrijke aspecten (centrale tot meer rechtse ligging op de $\mathrm{x}$-as), al is hier ook geen grote eensgezindheid over (grote bubbels).

De volgende $\mathrm{PCl}$ plot (Figuur 51) geeft aan in welke mate de licentiehouders akkoord of helemaal niet akkoord gaan met bepaalde uitspraken over de kenmerken van het gebruik van licenties zoals toegepast in het proefproject. Figuur 51 illustreert dat de bevraagde licentiehouders het allemaal eens zijn dat licentiejacht de terreinbeheerder toelaat om het vooropgestelde afschot op korte termijn te laten uitvoeren (rechtse ligging op de $x$-as, kleine bubbel met $\mathrm{PCl}$ van 0,04). Ook het feit dat licentiejacht in vergelijking tot de klassieke 3/6/9 verpachting aan meer mensen de mogelijkheid geeft om te jagen in overheidsgebieden, was een uitspraak waar de meeste respondenten akkoord mee waren. Het minst akkoord waren de licentiehouders met de uitspraak dat het licentiesysteem nadeliger zou zijn voor omliggende WBE's dan een klassieke 3/6/9 verpachting, al is er hierover minder eensgezindheid in de antwoorden dan over de vorige twee vragen (grotere bubbel). Uitspraken dat licentiejacht resulteert in minder selectief afschot, dat licentiejacht een ideaal instrument vormt voor de overheid om bejaging te combineren met de recreatiefunctie van overheidsgebieden, dat jagers sneller de trekker overhalen omdat men geen zekerheid heeft over meerjarenpacht, dat licentiejacht vooral geschikt is voor reewildbeheer en minder voor everzwijnbeheer, en dat licentiejacht financieel interessanter is voor jagers dan een part voor grofwild buiten Vlaanderen, zijn allemaal uitspraken die een neutrale tot belangrijk element blijken te vormen, maar waarbij er een grote variatie is in de meningen van de licentiehouders. Opvallend is dat het grootste meningsverschil bestaat over de vraag of de licentiehouder nu wel of niet sneller de trekker zal overhalen (zie ook 5.2). Maar ondanks de grote spreiding, neigt de gemiddelde score zowel voor de uitspraak dat er sneller de trekker overgehaald wordt als over de uitspraak dat er minder selectief gejaagd wordt, naar 'akkoord' (positieve waarde). 


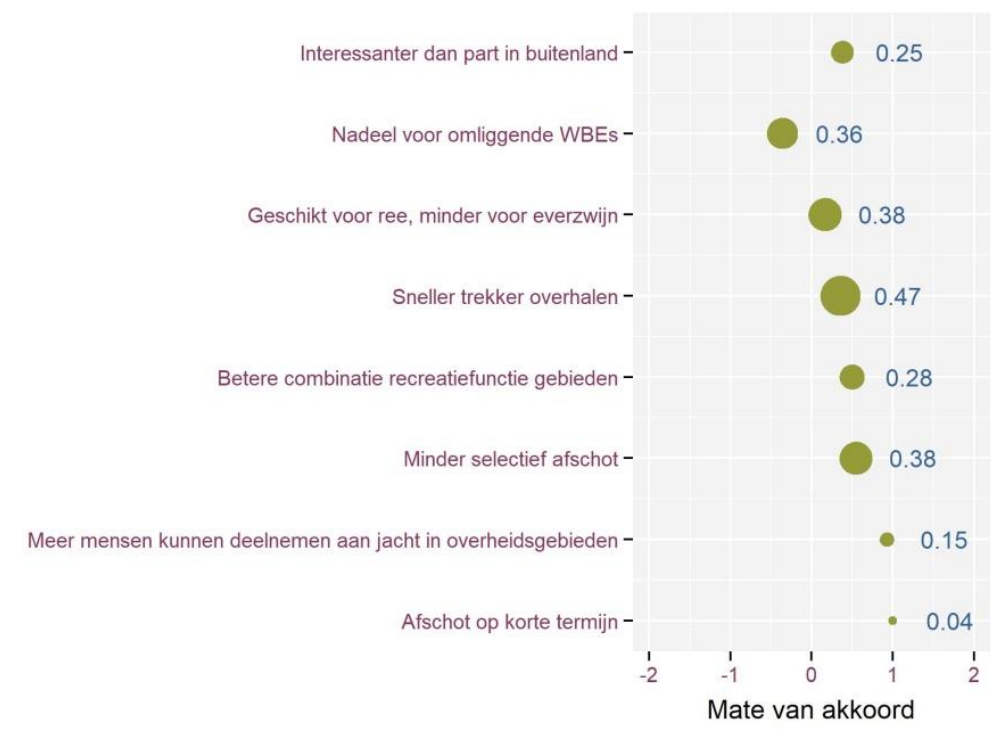

Figuur 51: $\mathrm{PCl}$ plot dewelke beschrijft in welke mate respondenten akkoord zijn met bepaalde uitspraken over het licentiejachtproject. Respondenten konden deze uitspraken scoren van 'helemaal niet akkoord' tot 'helemaal akkoord'. Hoe groter de bubbel, hoe groter de variatie in meningen. Hoe kleiner de bubbel, hoe groter de eensgezindheid. Het getal geeft de PCl-waarde weer. Deze varieert tussen 0 (helemaal geen meningsverschillen) en 1 (opvattingen liggen totaal uit elkaar)

\subsubsection{Subthema 3: jachtdagboekjes}

Als laatste aspect van deze bevraging, werd gevraagd hoe de licentiehouders het gebruik van jachtdagboekjes hebben ervaren. 90\% van de respondenten vond de jachtdagboekjes gebruiksvriendelijk (64\%) tot heel gebruiksvriendelijk (26\%). Geen van de respondenten vond de jachtdagboekjes niet gebruiksvriendelijk (Figuur 52). 97,6\% van de licentiehouders denkt dat er geen invulmogelijkheden ontbreken in de huidige jachtdagboekjes (Figuur 53). 57,1\% van de licentiehouders zou een digitale applicatie via de smartphone verkiezen boven het invullen van de analoge jachtdagboekjes.

Helemaal niet gebruiksvriendelijk - $\quad 0 \%$

Niet gebruiksvriendelijk - $\quad 0 \%$

Neutraal -

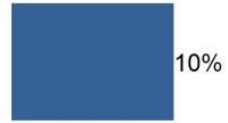

Gebruiksvriendelijk -

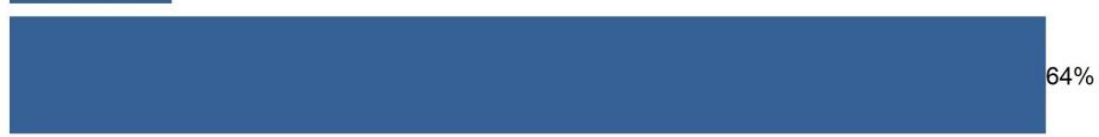

Heel gebruiksvriendelijk -

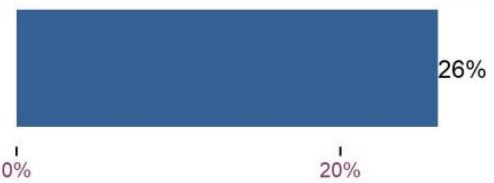

$40^{\prime} \%$

$60 \%$

Figuur 52: Meningen van de licentiehouders over de gebruiksvriendelijkheid van de jachtdagboekjes 


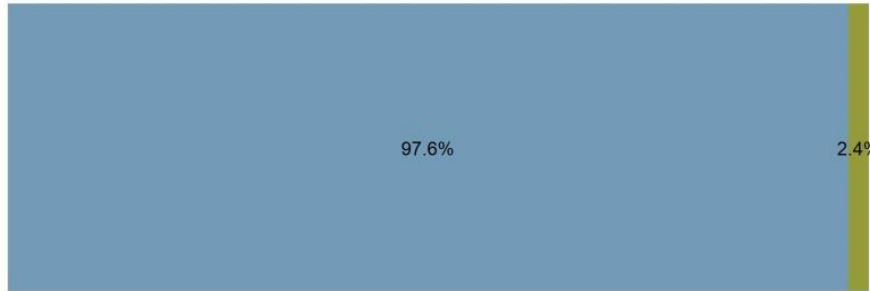

Een digitale app is beter dan jachtdagboekjes

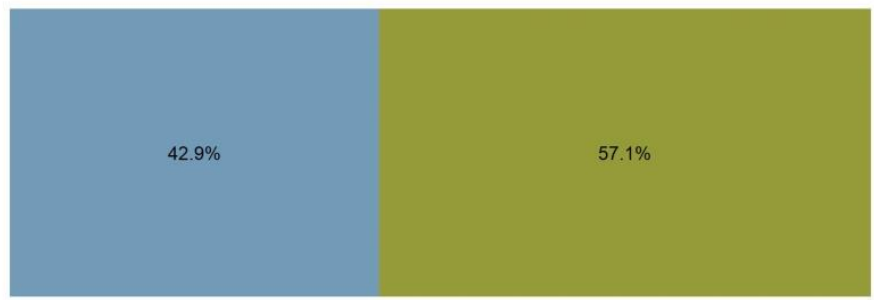

Figuur 53: Meningen over verbeteringen of aanpassingen aan jachtdagboekjes

\subsection{BEVRAGING VAN DE JACHTSECTOR}

\subsubsection{Inleiding}

Om een beter zicht te krijgen op mogelijke vragen en bezwaren, en op de houding van de jachtsector tegenover het toepassen van afschotlicenties, werd naar aanleiding van de stuurgroep en op een ANB - HVV overleg afgesproken dat gesprekken zouden plaatsvinden tussen het INBO - gezien haar rol in de wetenschappelijke evaluatie van het pilootproject - en vertegenwoordigers van de jachtsector. $\mathrm{Er}$ werd overeengekomen te overleggen met vertegenwoordigers van de omliggende WBE's, van de jagers in Limburg - gezien ook daar in sommige overheidsgebieden afgeweken wordt van de klassieke jachtverpachting - en met een vertegenwoordiging van de belangenvereniging van de jachtsector (HVV).

Deze gesprekken vonden steeds plaats met volgende stramien: (1). Eerst werd kort geschetst wat er onder het toepassen van afschotlicenties werd verstaan (zie Hoofdstuk 2). (2) Vervolgens werd het gesprek gekaderd binnen de wetenschappelijke evaluatie van het pilootproject en het deelaspect van het draagvlak voor deze vorm van jachtverpachting. Hierbij werd aangegeven dat het ging over de evaluatie van de verpachtingsvorm op zich, hoe deze toegepast werd of kan worden en niet over de gekozen reewildbeheerdoelstellingen in Ravels en Arendonk, noch over de omvang van het afschot. (3) De rest van het gesprek volgde een vrij verloop waarbij de deelnemers verschillende elementen aan bod brachten en het INBO naar bepaalde aspecten polste.

De deelnemers aan de gesprekken in Antwerpen en Limburg ontvingen na het gesprek een verslag van het overleg en konden hier nog aanvullingen of bemerkingen aan toevoegen. HVV ontving de gecompileerde tekst voor verdere aanvullingen en bemerkingen, ook voor wat betreft het gesprek dat met HVV zelf plaatsvond.

De onderstaande resultaten zijn de samenvatting van de drie gevoerde gesprekken. In alle gesprekken kwam de wettelijke dimensie van afschotlicenties, de economische kant ervan, het communicatief aspect, wederzijds respect, afstemming van doelstellingen en afschotlicenties in het algemeen aan bod. 


\subsubsection{Resultaten}

\subsubsection{Gebruik van afschotlicenties in het algemeen}

Uit de drie gesprekkenkwam naar voor dat men op zich niets tegen het principe van afschotlicenties heeft. Veel jagers nemen immers als gast deel aan buitenlandse jachten of jachtdagen in Wallonië, op terreinen waar ze zelf niet betrokken zijn bij het bepalen van de beheerdoelstellingen, de inrichting van het terrein of de organisatie en planning van de jachtactiviteiten. Daarnaast werd ook vaak aangegeven dat heel wat jagers in Vlaanderen onder een of andere vorm als licentiehouder in Duitsland jagen. Er werd ook in elk van de gesprekken aangegeven dat men kan begrijpen dat, in functie van een coherent en geïntegreerd bos- en wildbeheer, de overheid, NGO's of andere grote privé terreineigenaars ervoor kiezen om zelf het jachtbeheer en het jachtrecht in handen te houden en het afschot daarom via afschotlicenties willen laten uitvoeren.

De vraagtekens die geplaatst werden bij het gebruik van afschotlicenties betreffen bijgevolg vooral de toepassing ervan in Vlaanderen, het hoe en waarom de overheid hiertoe overgaat, het algemeen 'nut' van het gebruik van afschotlicenties en onder welke omstandigheden deze toegepast worden.

\subsubsection{Wettelijke aspecten}

In elk van de drie gesprekken werden vraagtekens geplaatst bij het wettelijke karakter van het gebruik van afschotlicenties in Vlaanderen.

Voor de toepassing van afschotlicenties binnen het proefproject in Antwerpen was er een duidelijk juridisch kader, met name een uitzondering op het Jachtdecreet in functie van wetenschappelijk onderzoek. Aan de hand van een besluit werden de randvoorwaarden bepaald waarop deze afwijking kon plaatsvinden en dit voor een looptijd van negen jaar vanaf oktober 2009. Na het verstrijken van deze negen jaar werd door de juristen van het ANB aangegeven dat het mogelijk was om aan de hand van duidelijke bepalingen in een verpachting verder te werken met een gelijkaardig systeem. Vanuit de sector zijn er steeds vragen gesteld bij deze visie, zeker voor wat betreft het toepassen van vormen van afschotlicenties buiten het proefproject nog voor het proefproject afgerond en geëvalueerd is.

Algemeen stelt de jachtsector de vraag of het toepassen van afschotlicenties mogelijk is onder artikel 11 van het Jachtdecreet dat stelt dat "Het jagen op de domeinen van openbare besturen is alleen geoorloofd ingevolge jachtrecht toegekend volgens de principes van mededinging en transparantie". Dit zou immers betekenen dat de licentiehouder voor de duur van de licentie en voor de sector waarvoor hij een licentie heeft, alsook gedurende de drukjachten waaraan hij mag deelnemen het jachtrecht toegekend gekregen heeft, en hierdoor een aantal rechten en plichten krijgt, voor zover deze niet anders bepaald worden in de verpachting. Ook werd in vraag gesteld of het systeem waarbij licentiehouders op initiatief van ANB ook op andere terreinen uitgenodigd kunnen worden om deel te nemen aan een drukjacht of gemeenschappelijke aanzit, niet in strijd is met de bepalingen van artikel 11 van het decreet.

Ook rezen vragen over hoe dit dan past binnen de bepalingen dat jachtrechthouders kunnen aansluiten bij een wildbeheereenheid, de jachtrechthouder een jachtplan moet indienen, een afschotplan aanvraagt ...

Deze wettelijke onduidelijkheid heeft er ook toe geleid dat er op dit moment ook buiten het proefproject op sommige plaatsen gesproken wordt over 'licentiejacht', waarbij het over een verpachting voor langere periodes (maanden) gaat, eventueel zelfs voor een jaar en met IIIIIIIIIIIIIIIIIIIIIIIIIIIIIIIIIIIIIIIIIIIIIIIIIIIIIIIIIIIIIIIIIIIIIIIIIIIIIIIIIIIIIIIIIIIIIIIIIIIIIIIIIIIIIIIIIIIIIIII 
mogelijk stilzwijgende verlenging. Ook werd het op sommige plaatsen niet steeds beperkt tot 1 licentie voor 1 persoon maar kon het gaan over sectoren die aan een beperkt aantal jagers $(1+1$ of $1+3)$ voor een korte periode verpacht werden. Hierdoor is het op dit moment niet meer duidelijk wat er juist wel of niet valt onder de term licentiejacht.

Verschillende keren werd in deze gesprekken duidelijk benadrukt dat de vraag naar de wettelijke aspecten van het gebruik van afschotlicenties niet het principe van afschotlicenties in vraag wil stellen, maar wel een vraag is om, als men het wil toepassen, er ook voor te zorgen dat het wettelijk volledig in orde is en er een wettelijke basis voor bestaat. Daarnaast werd ook aangegeven dat het onduidelijk is of ANB als jachtrechthouder wel of niet kan toetreden tot een wildbeheereenheid. Bovendien werd de vraag geopperd of indien dit wel kan of zou kunnen, dit niet tot belangenconflicten leidt. Het feit dat het gebied niet tot de wildbeheereenheid hoort en er dus niet afgestemd moet worden over het te voeren beheer en de beheerdoelstellingen, werd als een algemeen probleem ervaren (zie ook verder).

De huidige wettelijke onduidelijkheden en/of interpretatie ervan door het ANB leidt ertoe dat bij sommigen de indruk leeft dat het ANB de wettelijke bepalingen leest in functie van zijn eigen behoeften en wensen. Dit heeft op zijn beurt een negatieve impact op het vertrouwen vanuit de jachtsector naar de overheid toe.

Bovendien werd ook aangebracht dat wanneer het gebruik van afschotlicenties gemotiveerd wordt vanuit het feit dat hierdoor ingezet kan worden op kortere perioden (enkele dagen) binnen de wettelijke openingsperioden, een gekend aantal jagers, degelijke en frequente opvolging van het beheer en afschot a.d.h.v. jachtdagboekjes enz., elk van deze elementen ook via een duidelijk omschreven en opgevolgd lastenboek kan bedwongen worden, dus zonder de noodzaak van juridische aanpassingen voor het invoeren van afschotlicenties.

Verschillende keren werd aangehaald dat de indruk leeft dat er door de overheid gekozen wordt voor afschotlicenties vanuit de wil om de 'touwtjes' terug in handen te nemen en dit vanuit een gebrek aan vertrouwen naar de jachtsector als betrouwbare partner voor het uitvoeren van het wildbeheer en het bereiken van vooropgestelde beheerdoelstellingen. Het feit dat de redenen waarom voor afschotlicenties eerder dan een klassieke verpachting gekozen wordt niet transparant meegedeeld werd, lijkt hier zeker in mee te spelen (zie verder).

\subsubsection{Economische en beheertechnische kant}

Een van de gevolgen die het gebruik van afschotlicenties met zich meebrengt, is dat de terreineigenaar/beheerder zorgt voor de nodige infrastructuur om de bejaging mogelijk te maken en ook instaat voor het organiseren en in goede banen leiden van de jachtactiviteiten. Dit veronderstelt dat, zoals toegepast in het proefproject, de beheerder de nodige inspanningen levert om een degelijke monitoring van de geleverde jachtinspanningen, populatietrends en bio-indicatoren toe te passen, nodig voor een onderbouwde evaluatie en bijsturing van het wildbeheer. Verschillende keren werd geopperd dat het toch wel een raar gegeven is dat de overheid geld tekort heeft en moet besparen, maar kiest voor een vorm van jachtverpachting waarbij ze zelf meer moet investeren in jachtinfrastructuur en personeel dan bij een klassieke verpachting. Bij deze laatste zijn al deze lasten en kosten immers veelal voor de jachtpachter.

Daarnaast werd een aantal keren aangehaald dat zowel de inrichting van de jachtinfrastructuur op het terrein als alle elementen die te maken hebben met de praktische doorvoering van de jacht heel wat expertise en kennis vergen. Verschillende keren werd aangegeven dat het pilootproject slechts mogelijk was door de inbreng gedurende het hele 
project van tijd, kennis en ervaring van één à twee zeer gemotiveerde en ervaren lokale jagers, de omkadering door INBO én de ervaring van de lokale regiobeheerder, zowel als door de goede samenwerking ertussen die reeds voor het pilootproject bestond. De vraag werd openlijk gesteld of er binnen ANB op Vlaams niveau wel voldoende kennis, ervaring en tijd voorhanden is, of beschikbaar gemaakt kan worden, om een dergelijke inbreng, nodig voor een succesvol beheer door middel van afschotlicenties, ook op andere plaatsen te realiseren. Er werd ook aangegeven dat het succesvol toepassen en uitbreiden naar andere gebieden van het gebruik van afschotlicenties, een verdere investering vanuit ANB in deze kennis en kunde zal vergen en/of een goede verankering en samenwerking met de mensen uit de lokale jachtsector nodig zal zijn zodat deze hun terreinkennis en ervaring kunnen inbrengen. De vraag werd door sommigen gesteld waarom de overheid hierin zou investeren als deze kennis nu reeds voorhanden is binnen de jachtsector en door een klassieke verpachting, zonder bijkomende investering vanuit de overheid, ingezet kan worden.

\subsubsection{Communicatie, afstemmingen en respect}

In elk gesprek kwam de vraag naar een betere en meer transparante communicatie over het waarom van de keuze voor het gebruik van afschotlicenties. Hierbij ging het zowel over de vraag welke doelstellingen nagestreefd worden/werden met het ree- of grofwildbeheer in het gebied, als over de vraag waarom het ANB ervoor kiest dit te doen aan de hand van afschotlicenties en niet met een normale verpachting. Het gaat hierbij dus zowel over een vraag naar het motiveren van de beheerdoelstellingen als over het motiveren van de keuze voor het inzetten van een bepaald instrument (in deze afschotlicenties). In diezelfde lijn vraagt men naar een duidelijk, transparant afwegingskader of set van criteria die gehanteerd (kunnen) worden door ANB om te beslissen om met afschotlicenties te werken dan wel met een klassieke jachtverpachting.

Er werd aangegeven dat enkel wanneer de doelstellingen vooraf gekend zijn, het mogelijk is na te kijken in hoeverre deze doelstellingen verwezenlijkt kunnen worden in samenwerking met de omliggende jachten of in strijd zijn met de beheerdoelstellingen van de omliggende jachten. Zo werd bijvoorbeeld aangegeven dat indien het ANB de licentiejacht in Ravels/Arendonk heeft ingesteld om de natuurlijke verjonging te verwezenlijken in het gebied door een hoger reeafschot, men dit ook eerst had kunnen proberen in samenwerking met de omliggende jachtterreinen door het afschot daar te verhogen. In een tweede fase had men, indien gebleken zou zijn dat het ook zo niet lukte, dan nog altijd voor andere opties kunnen gaan.

Er was zeker begrip voor het feit dat de doelstellingen kunnen verschillen en er eventueel geen synergiën mogelijk kunnen zijn in bepaalde gevallen, maar de vraag bleef bestaan om steeds eerst en meer af te stemmen met omliggende jachtterreinen en wildbeheereenheden alvorens keuzes te maken. Een paar keer werd aangehaald dat, hoewel de situatie van ANB als beheerder/eigenaar van een groot bos- en natuurcomplex vergeleken kan worden met die van een grote private eigenaar die zelf zijn eigen wildbeheerdoelstellingen en aanpak bepaalt, het feit dat het over overheidsdomeinen handelt, gefinancierd vanuit overheidsmiddelen, dit automatisch een grotere transparantie vereist. Hieraan werd ook gekoppeld dat waar keuzes voor eigen beheerdoelstellingen, gezien de specifieke multifunctionele beheercontext van overheidsgebieden, voor grote domeinen een terechte motivatie kan zijn voor een aanpak die afwijkt van de omliggende private terreinen, dit voor kleine gebieden moeilijk te verantwoorden is. Wild houdt zich immers niet aan eigendomsgrenzen en in het kader van een duurzaam populatiebeheer heeft de overheid zelf een minimum van 250 ha bos of dekking of 1000 ha jachtterrein als ondergrens voor een afschotplan op reewild opgelegd. 500 ha werd op een bepaald moment als minimale oppervlakte voor een 'eigen beheer' naar voor geschoven in een van de gesprekken. 
Algemeen leefde de indruk dat ANB hier zijn eigen keuzes maakt en gaat voor de beste optie vanuit de eigen visie en vooraf niet de verschillende mogelijke opties samen met de aangrenzende jachtrechthouders of wildbeheerheden bekeken heeft. In de verschillende gesprekken werd aangebracht dat dit aanvoelt als een contradictie met het door de overheid ingestelde idee dat wildbeheer jachtterreinoverschrijdend moet gebeuren en een afstemming van doelstellingen tussen aanliggende jachtterreinen cruciaal is voor een goed wildbeheer. Het feit dat de overheid eerst het instrument van wildbeheereenheden heeft ingesteld en dan zelf haar eigen terreinen uit de werking van de wildbeheereenheden haalt, werd verschillende keren als een pijnpunt aangehaald.

Wel werd er aangehaald bij het gesprek in de provincie Antwerpen dat voor wat betreft het everzwijnenbeheer er wederzijdse afstemming en overleg plaatsvindt.

De indruk leeft dat ANB bij het uitstippelen van het wildbeheer in haar domeinen weinig of geen rekening houdt met de beheerdoelstellingen, wensen en bezorgheden van de omliggende jachtterreinen. Een terugkerend element hierbij vormde de afstemming rond predatiecontrole in functie van de kleinwildjacht in omliggende jachtterreinen. Een groter respect voor de belangen van omliggende jachtterreinen door rekening te houden met hun prioriteiten en bezorgdheden en de mogelijke gevolgen van de beheerkeuzes in de ANB terreinen werd hier gevraagd van de overheid.

Ook de vraag om de lokale wildbeheereenheden of jachtgroepen bij het wildbeheer door de overheid een plaats als prioritaire partners te geven werd naar voor gebracht. De perceptie leeft dat door het systeem van afschotlicenties, maar ook doordat genodigden aan de drukjachten georganiseerd door ANB kunnen deelnemen, de lokale jagers soms te weinig een plaats krijgen in het wildbeheer door de overheid. Voor sommige lokale jagers voelt dit aan als dat zij het hele jaar moeite doen voor het wildbeheer - al dan niet in samenwerking met ANB maar op het moment er geoogst kan worden en/of er mogelijkheden zijn om te jagen, externen een voet tussen de deur krijgen of zelfs voorrang krijgen. Het feit dat men waarneemt dat soms overheidspersoneel deelneemt als jager aan drukjachten, lijkt deze perceptie nog te versterken. Voor verschillende mensen vormt juist het ontbreken van de lokale verankering van de licentiehouders en het feit dat ze als jager geen deel uitmaken van het bestaande netwerk van lokale jagers, een groot bezwaar tegen de licentiejacht. Voor hun wordt hierdoor de rol van de jager gereduceerd tot het schieten van een aantal dieren wat ver staat van het idee rond de responsabilisering van de jagers en de wildbeheereenheden in het kader van een duurzaam wildbeheer in een bepaald gebied. De vraag werd gesteld waarom geen vastgesteld percentage van de licenties bijvoorbeeld voor leden van de lokale wildbeheereenheid of inwoners van de gemeente gereserveerd zou kunnen worden. In Wallonië is dit laatste immers het geval in bepaalde gemeentebossen waar met afschotlicenties gewerkt wordt. In Vlaanderen maakt het recht van hoger bod voor een wildbeheereenheid het mogelijk dat de lokale wildbeheereenheid de jachtrechten kan verwerven indien het verpachte terrein binnen haar werkingsgebied ligt of er aan grenst.

In dezelfde lijn werd ook aangehaald dat de vroegere langlopende verpachtingen, en de situaties waarbij dezelfde jachtgroep na het verlopen van de verpachting het jachtrecht voor een tweede of derde periode pachtte, het mogelijk maakte dat de pachter van overheidsdomeinen een langlopende relatie met de buurjagers én met het lokale ANBpersoneel kon opbouwen. Hierdoor kon een vertrouwensrelatie opgebouwd worden en kennis makkelijk gedeeld worden, iets dat volgens sommigen met korte licenties en steeds wisselende licentiehouders niet (meer) mogelijk is. 


\subsubsection{Positieve elementen}

Tegelijkertijd werden in de gesprekken ook een aantal positieve elementen omtrent de licentiejacht aangehaald. Door de opgelegde minimale aanwezigheid krijgen vooral lokale jagers een kans. Bovendien krijgt een groter aantal verschillende mensen de kans om te jagen in overheidsgebied wat ook als positief werd ervaren. Ook het feit dat jonge jagers, voor wie het anders moeilijk kan zijn een jachtrecht te vinden, op deze manier kunnen beginnen jagen, in een wel omkaderde situatie en in samenwerking met andere licentiehouders zowel als met ANB, werd positief onthaald.

De samenwerking met de lokale beheerder en het lokaal personeel, die binnen het licentiejachtgebeuren veeleer een rol van gastheer en organisator opnemen, werd tevens als positief element vermeld.

\subsubsection{Samenvatting}

Uit de gevoerde gesprekken bleek dat hoewel het instrument van afschotlicenties gekend is en op zich ook door heel wat Vlaamse jagers in het buitenland of Wallonië beoefend wordt, er tal van elementen zijn die op dit moment een zekere weerstand tegen het gebruik ervan oproepen.

Elementen die telkens naar voor kwamen waren de wettelijke verankering ervan, de transparantie over het hoe en waarom, de afstemming rond beheerdoelstellingen, het betrekken van omliggende jachtterreinen in het kader van een jachtterreinoverschrijdend wildbeheer, wederzijds respect en algemene communicatie. Daarnaast kwamen in de gesprekken ook zeer vaak elementen aan bod die veel breder gingen dan de licentiejacht op zich als beheerinstrument, maar eerder te maken hebben met de algemene relatie tussen de jachtsector en de Vlaamse overheid. Elementen werden aangehaald zoals het uitkleuren van jachtgebieden van de overheid, de lokale relaties tussen bepaalde overheidsmensen en bepaalde jagers/jachtgroepen, het feit dat ANB uitzonderingen op de algemene regels van het Jachtdecreet toekent aan zichtzelf (artikel 33) en hierbij zowel rechter en partij is, afschotplannen goedkeurt, beslist over verpachtingen, beslist over schadevergoedingen en nieuwe wetten voorbereidt, alsook een gevoel dat de jachtsector steeds meer moet afstaan en beperkt wordt, maar ook dat haar expertise en kennis niet erkend worden.

Voor elk van de concrete bezwaren/pijnpunten die te maken hebben met de inzet van afschotlicenties als instrument voor het grofwildbeheer, kan vrij gemakkelijk een technische oplossing gevonden worden (aanpassen van de wetgeving, instellen van een minimale oppervlakte, instellen van een overlegplatform met omliggende WBE's, etc.). Duidelijk is echter dat er ook een aantal onderliggende elementen of pijnpunten zijn die door deze technische oplossingen niet verholpen zullen worden.

Deze situatie vertoont sterke gelijkenissen met wat meer en meer naar voor komt uit analyses van de verschillende elementen die een rol spelen bij 'conservation conflicts' (en het oplossen van conflicten tussen belanghebbenden in het algemeen). Hierbij wordt aangegeven dat bij meningsverschillen over natuurbeheer, en dus ook wildbeheer, er in veel gevallen onder het ogenschijnlijk makkelijk op te lossen meningsverschil, zich een meer fundamenteel en dieperliggend 'conflict' situeert (Figuur 54). Dit dieperliggend conflict kan zijn oorsprong vinden in vroegere niet opgeloste meningsverschillen of conflicten, dan wel in percepties van gebrek aan respect, gebrek aan wederzijds vertrouwen, onevenwichtige machtsverhoudingen, verschillen in 'waarden' of gerelateerd zijn aan een behoren tot een bepaalde groep (identiteit). Een duurzame oplossing zal in die situaties vergen dat niet enkel gewerkt wordt aan het wegwerken van de concrete meningsverschillen rond het actuele agendapunt (in dit 
geval de toepassing van de licentiejacht) maar ook dat er aandacht is voor de onderliggende vragen en het herstellen van de vertrouwensrelaties (Madden and McQuinn, 2014).

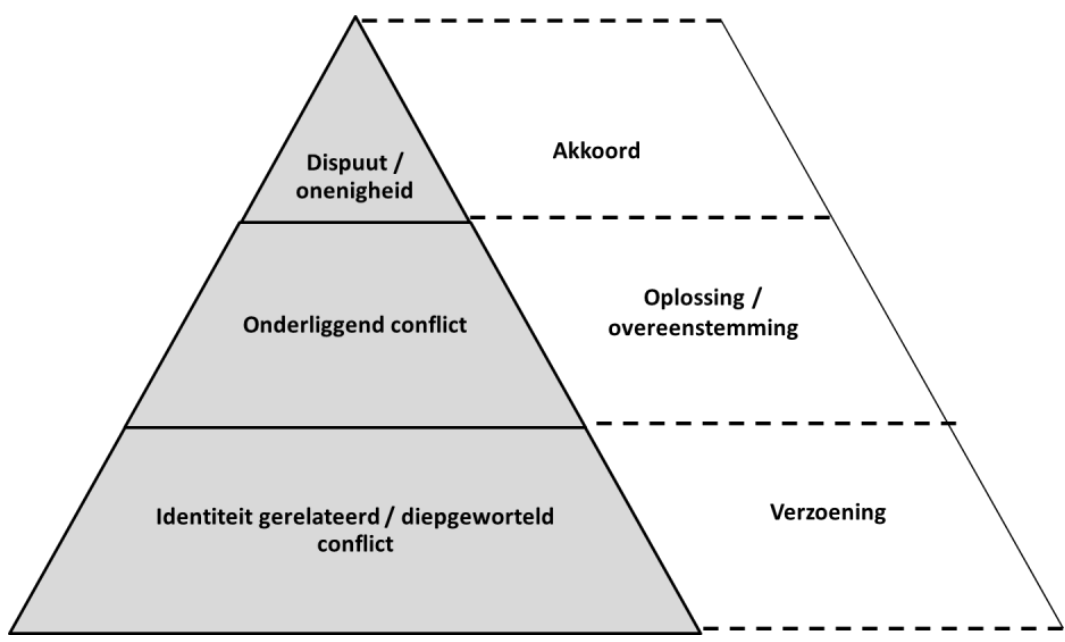

Figuur 54: Verschillende niveaus van meningsverschil of conflict die kunnen voorkomen bij natuur- of wildbeheer vraagstukken, elk met bijhorende aanpak (naar (Madden and McQuinn, 2014)

\subsection{CONCLLUSIES SOCOIO-ECONNOMISCHEASPECTEN}

Voor een diepgaande economische analyse van de verpachting onder vorm van licenties in vergelijking met klassieke verpachtingen of jacht, zijn te weinig gegevens beschikbaar. Een meer gedetailleerde economische analyse van de kosten en opbrengsten van licentiejacht voor de (ver)pachter zou zeker interessant zijn. Hierbij mag echter niet vergeten worden dat waarde van de jacht voor de jachtrechthouder/pachter heel wat meer kan omvatten dan het aantal dieren die jaarlijks geschoten kunnen worden of de grootte van het domein. Dit neemt echter niet weg dat opgemerkt moet worden dat aan het verpachten van de jacht via licenties inherent kosten verbonden zijn voor de overheid/terreinbeheerder zowel betreft infrastructuur (hoogzitten etc.) als personeelsinzet. De waargenomen toename van de prijs per licentie vanaf 2016 viel al dan niet toevallig samen met de opkomst van everzwijnen in het proefgebied en de daarbij horende mogelijkheid om als licentiehouder deel te nemen aan everzwijndrukjachten georganiseerd oor ANB. Daarnaast was de inkomst per 100 ha voor het ANB uit de licentiejacht van dezelfde grootteorde als van andere verpachtingen door het ANB.

De resultaten van de bevraging van de licentiehouders zijn vrij tot zeer positief. De meerderheid ervaart hun deelname als positief tot zeer positief, en geeft aan dat de samenwerking met de overheid en tussen de licentiehouders goed tot zeer goed was. De meerderheid vond dat ze voldoende inzichten had in de motieven achter beslissingen van ANB, ziet het systeem ook als een mogelijkheid in andere gebieden en zou andere ook aanraden als licentiehouder deel te nemen. De meerderheid zou ook in de toekomst zelf terug deelnemen als licentiehouder. Zo goed als allemaal waren ze het eens met de uitspraak dat het systeem toelaat op korte periode het voorziene afschot te realiseren en dat het daarnaast toelaat dat meer mensen kunnen jagen op overheidsgebied. Tussen de licentiehouders waren de meningen het meest verdeeld over de mate waarin het systeem nadelig is voor de omliggende WBE's, men sneller en minder selectief schiet en over de uitspraak dat het systeem vooral geschikt is voor ree en minder voor everzwijn.

Uit de gesprekken met lokale, provinciale (Antwerpen, Limburg) en regionale vertegenwoordigers van de jachtsector komt naar voor dat het systeem van licenties gekend 
is en door de sector op zich niet negatief beoordeeld wordt als verpachtingsvorm, maar dat er een aantal vragen leven rond de toepassing ervan in Vlaanderen. Het betreft dan de wettelijke verankering en onduidelijkheden hierover, de communicatie en afstemming met de omliggende WBE's, zeker wat betreft de beheerdoelstellingen, en het betrekken van omliggende WBE's en jachtrechthouders in de beslissingen die een gebiedsoverschrijdend effect kunnen hebben. Ook werd erop gewezen dat de toepassing van licentiejacht de nodige expertise, tijd en middelen zal vergen van het ANB. Uit de gesprekken kwamen echter ook dieperliggende elementen naar voor die te maken hebben met de relatie tussen de Vaamse overheid en de jachtsector en het wederzijds respect en vertrouwen tussen beiden. Voor de concrete vragen en bekommernissen lijken vrij eenvoudig oplossingen gevonden te kunnen worden indien de betrokken partijen dit wensen. De nodige aandacht zal hierbij echter moeten gaan naar onderliggende verschillen in meningen en visies en mogelijke diepliggendere conflicten die hieruit ontstaan zijn of voortvloeien. 


\section{ALGEMENE CONCLUSIES}

Dit rapport behandelt verschillende dimensies van het proefproject rond de licentiejacht in de overheidsbossen van Ravels en Arendonk in de periode 2010 - 2019. Bij de verpachting onder vorm van licenties verwierven de licentiehouders de toelating tot jagen onder bepaalde voorwaarden voor een korte periode (vastgelegd aantal dagen in winter of zomer).

Het systeem liet de terreinbeheerder per deelgebied toe jaarlijks bij te sturen in functie van het verwezenlijken van de vooropgestelde doelen. Zo konden bijvoorbeeld het aantal licenties, de jachtperiodes zowel als het aantal gemeenschappelijke aanzitmomenten worden gewijzigd. Deze werkwijze resulteerde in een afschotrealisatie die doorheen het project hoger lag dan gemiddeld in Vlaanderen.

Tijdens het project noteerden de licentiehouders de gegevens van elke aanzit in een jachtdagboekje. Ook werden de reepopulaties in beide deelgebieden opgevolgd aan de hand van gestandaardiseerde kilometertellingen. De tellingen toonden aan dat de hoge afschotrealisatie resulteerde in de vooropgestelde daling van de reewildstand in beide deelgebieden. Uit de analyse van de jachtdagboekjes blijkt dat gelijklopend hieraan het aantal waargenomen reeën per aangezeten uur daalde en dat de tijd tot de eerste reewaarneming gedurende een aanzit toenam. Wel bleef het aandeel aanzitten met waarnemingen van reeën zo goed als gelijk doorheen het project.

Gedurende het project stelden we een stijging van de onderkaaklengtes en van de leeggewichten van de kitsen vast. Beide parameters zijn voor reewild gevalideerde bioindicatoren die een beeld geven van de verhouding tussen de draagkracht van het gebied en de aanwezige reewildstand. Het lag dan ook binnen de verwachtingen dat deze indicatoren zouden stijgen bij een populatiedaling. Zeker omdat beide waarden, in vergelijking met andere gebieden in Vlaanderen uit dezelfde periode, relatief laag waren bij de start van het project.

Het beoogde effect wat betreft de daling van de druk door reeën op de bosverjonging, kon slechts gedeeltelijk geëvalueerd worden, doordat de eerste terreinopnamen hiervoor pas in 2016 plaatsvonden. Op dat moment was het project al zes jaar bezig en was de populatie in beide deelgebieden al gedaald. Tussen 2016 en 2019 werd een lichte maar niet significante daling in de algemene druk van ree op houtige plantensoorten waargenomen. De druk op de loofboomsoorten en struikgewas was hoger dan op de naaldboomsoorten. Een aandachtspunt voor verder onderzoek was het groot aantal opnameplots in het bos waar geen houtige plantensoorten aanwezig waren.

Doordat buiten het proefgebied een aantal jagers vrijwillig gebruik maakten van jachtdagboekjes, konden de jachtefficiëntie (afschot per aangezeten uur) en de selectiviteit (\% van de waarnemingen waarbij ook geschoten werd) vergeleken worden binnen en buiten het proefgebied. De interpretatie van deze resultaten vraagt de nodige voorzichtigheid omdat het aantal jagers die buiten het proefproject jachtdagboekjes bijhielden beperkt was en erg fluctueerde. De data van buiten het proefgebied kunnen dus niet als een representatieve steekproef voor Vlaanderen beschouwd worden. Uit deze vergelijking blijkt dat de licentiehouders vaker ( 1 afschot op 3 waarnemingen) tot afschot kwamen dan de jagers buiten het proefgebied (1 op 5) (significant verschil). De jachtefficiëntie was iets hoger voor de licentiehouders, maar dit verschil is niet significant. 
De verpachting onder vorm van licenties liet toe om in een zeer beperkte en geconcentreerde periode, een hoger dan gemiddeld afschot te realiseren en een daling van de voorjaarsstand tot stand te brengen.

Voor een diepgaande economische vergelijking tussen de verpachting onder vorm van licenties en klassieke verpachtingen, zijn te weinig gegevens beschikbaar. Vast staat wel dat aan het verpachten van de jacht via licenties inherent kosten verbonden zijn voor de overheid/terreinbeheerder voor wat betreft infrastructuur (bv. hoogzitten) en de inzet van personeel.

Licenties worden toegekend aan de hoogste bieders. Wel werd geconstateerd dat de prijs per licentie vanaf 2016 toeneemt, wat, al dan niet toevallig, samenvalt met de opkomst van everzwijnen en de daarbij horende mogelijkheid om als licentiehouder deel te nemen aan everzwijndrukjachten georganiseerd door ANB. De inkomst per 100 ha uit de licentiejacht was van dezelfde grootteorde als van andere verpachtingen door het ANB.

De resultaten van een bevraging van licentiehouders zijn in het algemeen positief tot heel positief. De meeste licentiehouders zouden in de toekomst terug deelnemen, zien het als een systeem dat ook in andere overheidsgebieden toegepast kan worden en zouden andere jagers ook aanraden er aan deel te nemen. De meningen tussen de licentiehouders waren het meest verdeeld over de mate waarin het systeem nadelig is voor de omliggende WBE's en jachtrechthouders, de selectiviteit van het afschot en over de uitspraak dat het systeem vooral geschikt is voor ree en minder voor everzwijn.

Uit gesprekken met vertegenwoordigers van de jachtsector blijkt dat, eerder dan met het systeem van verpachtingen via licenties op zich, er een aantal heel concrete, maar technisch relatief eenvoudig te overkomen problemen ervaren worden met de toepassing ervan in Vlaanderen. Wel blijkt dat er onderliggende gevoeligheden en spanningen zijn tussen de jachtsector en de overheid die de nodige aandacht vergen om een constructieve samenwerking rond het wildbeheer in de toekomst te verzekeren. Hierbij nemen de afstemming rond beheerdoelstellingen, het betrekken van omliggende jachtterreinen bij jachtterreinoverschrijdend wildbeheer, wederzijds respect en een transparante communicatie een centrale plaats in voor de jachtsector. 


\section{METHODOLOGISCHE AANDACHTSPUNTEN VOOR DE TOEKOMST}

Het proefproject liet het INBO toe een aantal instrumenten in het kader van het adaptief grofwildbeheer in Vlaanderen verder op punt te stellen.

De kilometertellingen te voet in combinatie met het opvolgen van de onderkaaklengte en de leeggewichten van de kitsen toonden in dit project opnieuw hun meerwaarde als eenvoudig toepasbare instrumenten voor een transparant, adaptief reewildbeheer. Het ontbreken van reevraatmetingen vanaf de start van het project vormde duidelijk een gemis en het operationaliseren van het opvolgen van de druk op de vegetatie samen met de andere bioindicatoren, moet in de toekomst een extra aandachtspunt vormen. Het opnameprotocol en de analysemethoden voor de kleine opnameplots $(1 \mathrm{~m} 2)$ bleken goed te implementeren, maar de methodes voor het opnemen van reevraat binnen en buiten de reewerende rasters moeten verder uitgewerkt worden. Een afstemming met de in Wallonië toegepaste methode lijkt aangewezen.

Het meten van de afstanden bij elke waarneming van reeën tijdens de kilometertellingen bewees zijn meerwaarde. Een algemene toepassing ervan bij het uitvoeren van kilometertellingen lijkt zinvol.

Het gebruik van jachtdagboekjes als instrument om op een gestandaardiseerde wijze jachtdata te verzamelen bewees eveneens zijn meerwaarde om kennis te verwerven over de geleverde inspanningen, jachtefficiëntie en selectiviteit. Daarnaast liet de opgedane ervaring het INBO toe om het gebruik ervan te verfijnen. De controle op de volledigheid en nauwgezetheid bij het invullen van de jachtdagboekjes is hierbij belangrijk. De deelnemende jagers vonden de jachtdagboekjes gebruiksvriendelijk tot zeer gebruiksvriendelijk. De meerderheid geeft ook aan dat een digitale app (smartphone) voor deze dataverzameling wenselijk is. 


\section{Referenties}

ANB, 2008a. Uitgebreid bosbeheerplan domeinbos Hoge Vijvers rapport, in: Bos, A.v.N.e. (Ed.). Agentschap voor Natuur en Bos.

ANB, 2008b. Uitgebreid bosbeheerplan voor domeinbos Gewestbos Ravels rapport, in: Bos, A.v.N.e. (Ed.), Eindrapport 816111. Agentschap voor Natuur en Bos, p. 137.

Blant, M., Gaillard, J.M., 2004. Use Of Biometric body variablesas indicators of roedeer (capreolus capreolus) population density changes, pp. 21-40.

Bosdecreet, 1990. Bosdecreet, Vlaamse overheid. Vlaamse overheid.

Casaer, J., 2003. Analysing roe deer habitat selection: methodological problems and possible solutions., Applied Biological Sciences. Katholic University Leuven, Belgium, Leuven, p. 197.

Casaer, J., Huysentruyt, F., 2017. Beheer- en beleidsdoelen voor wildsoorten in Vlaanderen. Instituut voor Natuur- en Bosonderzoek.

Casaer, J., Huysentruyt, F., Vercammen, J., Malengreaux, C., Licoppe, A., 2017. Ondersteuningsproject bij de uitvoering van de reemonitoring in het Zoniënwoud/Mission d'appui pour le recensement du chevreuil dans le massif sonien. Jaarlijks rapport / Rapport annuel. Periode / Période de référence : 2008-2017. Instituut voor Natuur- en Bosonderzoek, Brussels.

Casaer, J., Malengreaux, C., 2008. Studie ter voorbereiding van het monitoren van de reewildpopulatiegrootte in Zoniën, Rapporten van het Instituut voor Natuur-en Bosonderzoek. Institituut voor Natuur- en Bosonderzoek, Brussels p. 40.

Gregory, R., Failing, L., Harstone, M., Long, G., McDaniels, T., Ohlson, D., 2012. Structured Decision Making. A practical Guide to Environmental Management Choices. Wiley-Blackwell.

Hammond, J.S., Keeney, R.L., Raiffa, H., 2002. Smart Choices, A Practical Guide to Making Better Decisions, Boston.

Huysentruyt, F., Casaer, J., 2012. Driejarenafschotplan voor reewild. Het gebruik van bioindicatoren en jachtgegevens voor de toekenning van het afschot bij ree., Rapporten van het Instituut voor Natuur- en Bosonderzoek. Instituut voor Natuur- en Bosonderzoek, Brussel, p. 68.

Kjellander, P., 2000. Density dependence in roe deer population dynamics. Swedisch University of Agricultural Sciences, Uppsala, p. 127.

Madden, F., McQuinn, B., 2014. Conservation's blind spot: The case for conflict transformation in wildlife conservation. Biological Conservation 178, 97-106.

Michallet, J., Pellering, M., Garel, M., Chevrier, T., Saïd, S., Saint-Andrieux, C., Hars, J., Rossie, S., Maillard, D., Klein, F., 2015. Vers une nouvelle gestion du grand givier: les indicateurs de changement écologique. Office Nationale de la Chasse et de la Faune Sauvage, Jouve, p. 64.

Morellet, N., Campely, S., Gaillard, J.M., Ballon, P., Boscardin, Y., 2001. The browsing index: new tool uses browsing pressure to monitor deer populations. Wildlife Society Bulletin 29, 1243-1252.

Morellet, N., Gaillard, J.M., Hewison, A.J.M., Ballon, P., Boscardin, Y., Duncan, P., Klein, F., Maillard, D., 2007. Indicators of ecological change: new tools for managing populations of large herbivores. Journal of Applied Ecology 44, 634-643.

ONCFS, 2015a. Fiche $\mathrm{N}^{\circ} 13$ : Indice de Consommation (IC), in: Sauvage, O.N.d.I.C.e.d.I.F. (Ed.), p. 5.

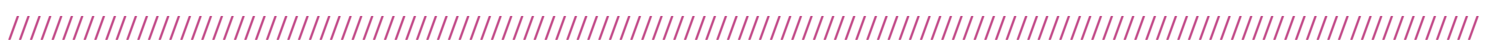


ONCFS, 2015b. Vers une nouvelle gestion du grand gibier : les indicateurs de changement écologique, in: Sauvage, O.N.d.I.C.e.d.I.F. (Ed.).

Pellerin, M., Bessière, A., Maillard, D., Capron, G., Gaillard, J.-M., Michallet, J., Bonenfant, C., 2017. Saving time and money by using diurnal vehicle counts to monitor roe deer abundance. Wildlife Biology 1, wlb.00274.

Pellerin, M., Chevrier, T., Capron, G., Vital, F., Bride, F., Michallet, J., 2014. I'ik voiture : un outil efficace pour le suivi du chevreuil aux échelles opérationnelles. Faune Sauvage 305, 4-9.

Runge, M.C., Grand, J.B., Michell, M.S., 2013. Sturctured Decision Making, in: Krausman, P.R., Cain, J.W. (Eds.), Wildlife Management \& Conservation. The John Hopkins University Press, Baltimore, p. 342.

Vaske, J.J., Beaman, J., Barreto, H., Shelby, L.B., 2010. An Extension and Further Validation of the Potential for Conflict Index. Leisure Sciences 32, 240-254.

Vaske, J.J., Needham, M.D., Newman, P., Manfredo, M.J., Petchenik, J., 2006. Potential for Conflict Index: Hunters' Responses to Chronic Wasting Disease. Wildlife Society Bulletin 34, 4450.

Vercammen, J., Huysentruyt, F., Casaer, J., 2011. Reewildtellingen. Overzicht van de resultaten uit de verschillende gebieden, Rapporten van het Instituut voor Natuur- en Bosonderzoek. Instituut voor Natuur - en Bosonderzoek, Brussels, p. 45. 


\section{Bijlage 1: Vergelijking van verpachting via licenties en klassieke verpachting}

\begin{tabular}{|c|c|c|}
\hline & Verpachting via licenties* & Klassieke verpachting \\
\hline Looptijd & $\begin{array}{l}\text { Korte periode (van een paar } \\
\text { weken tot een paar jaar) }\end{array}$ & $\begin{array}{l}\text { Normaal } 3 / 6 / 9 \text { jaren maar andere } \\
\text { opties zijn mogelijk }\end{array}$ \\
\hline Beheermethoden & $\begin{array}{l}\text { Drukjacht / aanzitjacht / vangen } \\
\text { /bersjacht** }\end{array}$ & $\begin{array}{l}\text { Drukjacht / aanzitjacht / vangen / } \\
\text { bersjacht* }\end{array}$ \\
\hline Aanstuurbaarheid beheer / afschot & $\begin{array}{l}\text { Grote aanstuurbaarheid van het } \\
\text { beheer door kortlopende } \\
\text { contracten die telkens aangepast } \\
\text { kunnen worden. Daarnaast laten } \\
\text { de bepalingen van de contracten } \\
\text { toe om het beheer flexibel bij te } \\
\text { sturen. Aantal licenties, aantal } \\
\text { periodes en beheermethoden } \\
\text { kunnen bijgestuurd en } \\
\text { gecombineerd worden. } \\
\text { Mogelijkheid om afschot (labels en } \\
\text { aantal jachtdagen) bij te sturen. }\end{array}$ & $\begin{array}{l}\text { Herziening van de } \\
\text { pachtvoorwaarden en bepalingen } \\
\text { binnen looptijd van contract enkel } \\
\text { mogelijk mits wederzijdse } \\
\text { goedkeuring. }\end{array}$ \\
\hline Jachtstrategie & $\begin{array}{l}\text { Mogelijkheid tot directe } \\
\text { aansturing van jachtstrategie door } \\
\text { geografische en temporele } \\
\text { spreiding van licenties. } \\
\text { Intervaljacht door middel van kort } \\
\text { lopende licenties mogelijk. }\end{array}$ & $\begin{array}{l}\text { Kan enkel indien vooraf ingebed in } \\
\text { verpachtingsvoorwaarden. } \\
\text { Intervaljacht moeten in de } \\
\text { verpachtingsvoorwaarden worden } \\
\text { opgenomen. }\end{array}$ \\
\hline Inzet ANB & $\begin{array}{l}\text { Vergt grotere inzet van ANB- } \\
\text { personeel en investeringen in } \\
\text { jachtinfrastructuur. } \\
\text { Vereist degelijke kennis van en } \\
\text { interesse in grofwildbeheer bij } \\
\text { ANB-personeel. Hoofdzakelijk } \\
\text { organiserende en coördinerende } \\
\text { functie. }\end{array}$ & $\begin{array}{l}\text { Inzet bij de opmaak van } \\
\text { verpachtingsvoorwaarden. } \\
\text { Hoofdzakelijk controlerende } \\
\text { functie gedurende de looptijd van } \\
\text { de verpachting. }\end{array}$ \\
\hline Overleg ANB - jagers & $\begin{array}{l}\text { Frequent overleg gedurende } \\
\text { uitvoering van het beheer in beide } \\
\text { richtingen }\end{array}$ & $\begin{array}{l}\text { Afspraken worden bij aanvang } \\
\text { gemaakt voor lange tijd. Overleg } \\
\text { enkel voor elementen die niet } \\
\text { verder bepaald zijn in de } \\
\text { verpachting. }\end{array}$ \\
\hline Overleg ANB - Wildbeheereenheid & $\begin{array}{l}\text { ANB in rol van wildbeheerder } \\
\text { maar is geen lid van WBE. Overleg } \\
\text { mogelijk (wenselijk) maar geen } \\
\text { afstemming wettelijk vereist. }\end{array}$ & $\begin{array}{l}\text { Jachtpachter is lid van de WBE. } \\
\text { Beheer van overheidsgebied } \\
\text { ingebed in faunabeheer WBE. }\end{array}$ \\
\hline $\begin{array}{l}\text { Verantwoordelijkheid voor } \\
\text { uitvoering van beheer en } \\
\text { mogelijke schade }\end{array}$ & ANB & Jachtpachters \\
\hline
\end{tabular}

* Onder licentie wordt hier steeds een toelating voor 1 persoon en niet overdraagbaar beschouwd

** Afhankelijk van mogelijkheden - inschatting van beheerder/verpachter 


\section{Bijlage 2: Aantal uren aanzit per geschoten ree}

\begin{tabular}{|c|c|c|c|c|c|c|c|c|c|c|}
\hline & 2010 & 2011 & 2012 & 2013 & 2014 & 2015 & 2016 & 2017 & 2018 & 2019 \\
\hline \multicolumn{11}{|l|}{ Winter } \\
\hline $\begin{array}{l}\text { Jagers buiten het } \\
\text { proefproject }\end{array}$ & & $8.28(27)$ & 17.96 (17) & $14.18(12)$ & $11.36(4)$ & $11.58(2)$ & $12.93(2)$ & $46.68(3)$ & $55.51(10)$ & $63.70(7)$ \\
\hline $\begin{array}{l}\text { Jagers buiten het } \\
\text { proefproject }\end{array}$ & & 32.01 (18) & 29.54 (12) & $22.73(8)$ & $5.41(3)$ & $5.43(2)$ & $27.78(2)$ & $22.18(2)$ & 20.15 (9) & $22.67(12)$ \\
\hline
\end{tabular}

Getal tussen haakjes geeft het aantal jachtdagboekjes weer voor een bepaalde combinatie van jaar, seizoen en jachtverpachtingstype 


\section{Bijlage 3: online enquête licentiehouders}

\begin{tabular}{|c|c|c|c|c|c|}
\hline 1 & In welke gemeente woont u? & & & & \\
\hline \multirow[t]{5}{*}{2} & \multirow{5}{*}{$\begin{array}{l}\text { Wat is de afstand van uw woonplaats tot de } \\
\text { jachtgebieden van Arendonk en Ravels? }\end{array}$} & \multicolumn{4}{|l|}{$0-5 \mathrm{~km}$} \\
\hline & & \multicolumn{4}{|l|}{$5-10 \mathrm{~km}$} \\
\hline & & \multicolumn{4}{|l|}{$10-20 \mathrm{~km}$} \\
\hline & & \multicolumn{4}{|l|}{$20-40 \mathrm{~km}$} \\
\hline & & \multicolumn{4}{|l|}{ Meer dan 40 km } \\
\hline \multirow[t]{3}{*}{3} & \multirow[t]{3}{*}{ Tot welke leeftijdscategorie behoort u? } & \multicolumn{4}{|l|}{ 20-40 jaar } \\
\hline & & \multicolumn{4}{|l|}{ 40-60 jaar } \\
\hline & & \multicolumn{4}{|l|}{ Ouder dan 60 jaar } \\
\hline \multirow[t]{3}{*}{4} & \multirow[t]{3}{*}{ Op welke wildsoorten jaagt u buiten de licentiejacht? } & \multicolumn{4}{|l|}{ Grofwild } \\
\hline & & \multicolumn{4}{|c|}{ Kleinwild en overig wild } \\
\hline & & \multicolumn{4}{|c|}{ Grofwild, kleinwild en overig wild } \\
\hline \multirow[t]{6}{*}{5} & \multirow{6}{*}{$\begin{array}{l}\text { In welke hoedanigheid jaagt } \mathrm{u} \text { in België op grofwild } \\
\text { buiten deze licentiejacht? }\end{array}$} & \multicolumn{4}{|c|}{ Op eigen terreinen (eigendom) } \\
\hline & & \multicolumn{4}{|c|}{ Eigen jachtterrein (hoofdjachtrechthouder) } \\
\hline & & \multicolumn{4}{|c|}{ Medejachtrechthouder } \\
\hline & & \multicolumn{4}{|l|}{ Genodigde } \\
\hline & & \multicolumn{4}{|l|}{ Licentiehouder } \\
\hline & & \multicolumn{4}{|l|}{ Niet } \\
\hline \multirow[t]{2}{*}{6} & \multirow{2}{*}{$\begin{array}{l}\text { Hoeveel jachtverloven heeft } u \text { al gehad? (jachtseizoen } \\
\text { 2019-2020 meegerekend) }\end{array}$} & \multicolumn{4}{|l|}{ In Vlaanderen } \\
\hline & & In Wallonië & & & \\
\hline 7 & Hoe bent u bij dit project terecht gekomen? & Via collega jagers & & & \\
\hline & & Via ANB personeel & & & \\
\hline & & Via ANB website & & & \\
\hline & & Via regiobeheerder & & & \\
\hline & & Via advertentie in V & & & \\
\hline & & Via nieuwsbrief hur & & & \\
\hline & & Andere (specifieer) & & & \\
\hline 8 & Duid aan in welke jaren u een licentie had voor & & 2010 & $\cdots$ & 2020 \\
\hline & Arendonk en/of Ravels en in welke periode & Zomer - Arendonk & & & \\
\hline & & Zomer - Ravels & & & \\
\hline & & Winter - Arendonk & & & \\
\hline & & Winter - Ravels & & & \\
\hline 9 & Had u voor uw deelname aan de licentiejacht in & Ja & & & \\
\hline & Ravels/Arendonk al eerder onder de vorm van & Nee & & & \\
\hline & & Indien ja, waar: & & & \\
\hline 10 & Jaagt u soms 1 of meerdere dagen buiten Vlaanderen op & Wallonië & & & \\
\hline & $\begin{array}{l}\text { terreinen waarvan u geen } \\
\text { jachtrechthouder/medejachtrechthouder bent? } \\
\text { (bijvoorbeeld als invité, genodigde of gedurende een } \\
\text { jachtreis) }\end{array}$ & In het buitenland & & & \\
\hline
\end{tabular}




\begin{tabular}{|c|c|c|c|c|c|c|c|}
\hline \multirow[t]{9}{*}{11} & \multirow{9}{*}{$\begin{array}{l}\text { Geef de mate aan } \\
\text { waarin de } \\
\text { onderstaande } \\
\text { redenen voor u } \\
\text { meespeelden om } \\
\text { deel te nemen aan } \\
\text { de licentiejacht }\end{array}$} & & 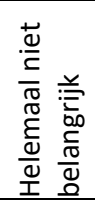 & 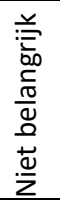 & $\begin{array}{l}\bar{\pi} \\
\frac{\pi}{2} \\
\stackrel{2}{2} \\
\frac{1}{2}\end{array}$ & 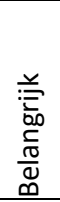 & 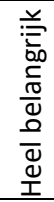 \\
\hline & & $\begin{array}{l}\text { Het geeft mij de mogelijkheid } \\
\text { dicht bij huis te jagen. }\end{array}$ & & & & & \\
\hline & & $\begin{array}{l}\text { Het geeft mij de mogelijkheid } \\
\text { ervaring op te doen als } \\
\text { grofwildjager doordat de } \\
\text { licentiejacht goed omkaderd is. }\end{array}$ & & & & & \\
\hline & & $\begin{array}{l}\text { Het is voor mij financieel beter } \\
\text { haalbaar dan elders een } \\
\text { jachtpacht te nemen. }\end{array}$ & & & & & \\
\hline & & $\begin{array}{l}\text { Het laat me toe gedurende een } \\
\text { korte periode van het jaar veel } \\
\text { jachtdagen te hebben en de rest } \\
\text { van het jaar met niet-jacht } \\
\text { gerelateerde zaken bezig te zijn. }\end{array}$ & & & & & \\
\hline & & $\begin{array}{l}\text { Het laat me toe gedurende een } \\
\text { korte periode van het jaar aan } \\
\text { licentiejacht te doen en en de } \\
\text { rest van het jaar op een andere } \\
\text { jacht actief te zijn. }\end{array}$ & & & & & \\
\hline & & $\begin{array}{l}\text { Ik ken(de) een deel van de } \\
\text { andere jagers en dit was een } \\
\text { fijne manier om samen met hen } \\
\text { te jagen. }\end{array}$ & & & & & \\
\hline & & $\begin{array}{l}\text { Ik was nieuwsgierig naar hoe } \\
\text { licentiejacht verloopt. }\end{array}$ & & & & & \\
\hline & & Andere (specifieer): & & & & & \\
\hline \multirow[t]{3}{*}{12} & \multirow{3}{*}{\multicolumn{2}{|c|}{$\begin{array}{l}\text { Zou u indien de mogelijkheid zich voordoet ook in de } \\
\text { toekomst terug willen meedoen aan jacht onder vorm } \\
\text { van licenties? }\end{array}$}} & \\
\hline & & & \multicolumn{5}{|l|}{$\begin{array}{l}\text { Ja } \\
\text { Nee }\end{array}$} \\
\hline & & & \multicolumn{5}{|c|}{ Licht uw mening toe indien u dit wilt: } \\
\hline \multirow[t]{3}{*}{13} & \multirow{3}{*}{\multicolumn{2}{|c|}{$\begin{array}{l}\text { Zou u andere mensen/collega-jagers aanraden ook deel } \\
\text { te nemen aan licentiejacht? }\end{array}$}} & \multicolumn{5}{|l|}{$\mathrm{Ja}$} \\
\hline & & & \multicolumn{5}{|l|}{ Nee } \\
\hline & & & \multicolumn{5}{|c|}{ Licht uw mening toe indien $\mathrm{u}$ dit wilt: } \\
\hline
\end{tabular}




\begin{tabular}{|c|c|c|c|c|c|c|c|}
\hline \multirow[t]{9}{*}{14} & \multirow{9}{*}{$\begin{array}{l}\text { Duid aan in welke } \\
\text { mate u zich kan } \\
\text { vinden in volgende } \\
\text { uitspraken over } \\
\text { licentiejacht in het } \\
\text { algemeen. Er wordt } \\
\text { hier steeds } \\
\text { uitgegaan van } \\
\text { kortlopende } \\
\text { licenties zoals } \\
\text { toegepast in Ravels } \\
\text { en Arendonk (dus } \\
\text { een licentie voor } \\
\text { een bepaalde } \\
\text { periode } \\
\text { (zomer/winter) van } \\
\text { een bepaald jaar) }\end{array}$} & & 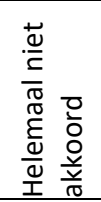 & 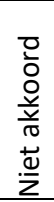 & 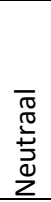 & $\begin{array}{l}\text { 뭉 } \\
\frac{0}{0} \\
\frac{1}{4} \\
\end{array}$ & 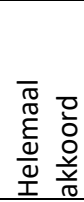 \\
\hline & & $\begin{array}{l}\text { Licentiejacht laat de } \\
\text { terreinbeheerder toe om op een } \\
\text { korte termijn het afschot, nodig } \\
\text { voor het reewildbeheer, uit te } \\
\text { laten voeren. }\end{array}$ & & & & & \\
\hline & & $\begin{array}{l}\text { Licentiejacht maakt het in } \\
\text { vergelijking tot een klassieke } \\
3 / 6 / 9 \text { verpachting mogelijk dat } \\
\text { meer mensen gebruik kunnen } \\
\text { maken van de mogelijkheid om } \\
\text { te jagen in overheidsgebieden }\end{array}$ & & & & & \\
\hline & & $\begin{array}{l}\text { Licentiejacht resulteert in een } \\
\text { minder selectief afschot }\end{array}$ & & & & & \\
\hline & & $\begin{array}{l}\text { Licentiejacht vormt een ideaal } \\
\text { instrument voor } \\
\text { overheidsgebieden omdat het } \\
\text { door de korte bejagingsperiode } \\
\text { beter te combineren is met de } \\
\text { recreatiefunctie van } \\
\text { overheidsgebieden. }\end{array}$ & & & & & \\
\hline & & $\begin{array}{l}\text { Licentiejacht geeft geen } \\
\text { zekerheid over een } \\
\text { meerjarenpacht wat ertoe leidt } \\
\text { dat men sneller de trekker zal } \\
\text { overhalen. }\end{array}$ & & & & & \\
\hline & & $\begin{array}{l}\text { Licentiejacht zoals uitgevoerd in } \\
\text { Ravels en Arendonk is vooral } \\
\text { geschikt voor reewildbeheer en } \\
\text { minder voor everzwijnenbeheer. }\end{array}$ & & & & & \\
\hline & & $\begin{array}{l}\text { Licentiejacht is nadeliger voor } \\
\text { de omliggende } \\
\text { wildbeheereenheden dan een } \\
\text { klassieke klassieke } 3 / 6 / 9 \\
\text { verpachting van } \\
\text { overheidsgebieden. }\end{array}$ & & & & & \\
\hline & & $\begin{array}{l}\text { Licentiejacht zoals in Ravels en } \\
\text { Arendonk is interessanter dan } \\
\text { een "part" voor grofwild buiten } \\
\text { Vlaanderen }\end{array}$ & & & & & \\
\hline \multirow[t]{4}{*}{15} & \multirow{4}{*}{\multicolumn{2}{|c|}{$\begin{array}{l}\text { Zou u het positief vinden als licentiejacht in de toekomst } \\
\text { ook in andere gebieden toegepast wordt of kan } \\
\text { worden? }\end{array}$}} & \multicolumn{5}{|l|}{$\mathrm{Ja}$} \\
\hline & & & \multicolumn{5}{|l|}{ Nee } \\
\hline & & & \multicolumn{5}{|c|}{ Geen mening } \\
\hline & & & \multicolumn{5}{|c|}{ Licht uw mening toe indien $\mathrm{u}$ dit wilt: } \\
\hline \multirow[t]{5}{*}{16} & \multirow{5}{*}{\multicolumn{2}{|c|}{$\begin{array}{l}\text { Bij licentiejacht worden heel wat beslissingen en acties } \\
\text { (zoals de omvang van het afschot, de plaatsing van de } \\
\text { hoogzitten, ... ) niet door de licentiehouder maar door } \\
\text { de terreinbeheerder genomen. Hoe staat u hier } \\
\text { tegenover? }\end{array}$}} & \multicolumn{5}{|c|}{ Heel negatief } \\
\hline & & & \multicolumn{5}{|c|}{ Negatief } \\
\hline & & & \multicolumn{5}{|c|}{ Neutraal } \\
\hline & & & \multicolumn{5}{|c|}{ Positief } \\
\hline & & & \multicolumn{5}{|c|}{ Heel positief } \\
\hline \multirow[t]{2}{*}{17} & \multirow{2}{*}{\multicolumn{2}{|c|}{$\begin{array}{l}\text { Heeft } u \text { als licentiehouder inspraak gehad op de } \\
\text { organisatie? }\end{array}$}} & \multicolumn{5}{|l|}{$\mathrm{Ja}$} \\
\hline & & & \multicolumn{5}{|l|}{ Nee } \\
\hline 18 & \multicolumn{2}{|c|}{ Heeft u zicht op de motieven van de beheerder voor de } & \multicolumn{5}{|l|}{ Ja } \\
\hline
\end{tabular}




\begin{tabular}{|c|c|c|c|c|c|c|c|}
\hline & \multirow{2}{*}{\multicolumn{2}{|c|}{ genomen beslissingen? }} & \multicolumn{5}{|l|}{ Nee } \\
\hline & & & \multicolumn{5}{|c|}{ Kan u zich hierin vinden? } \\
\hline 19 & \multicolumn{2}{|c|}{$\begin{array}{l}\text { Als u nog andere suggesties of meningen hebt rond } \\
\text { licentiejacht als verpachtingsvorm, die nog niet aan bod } \\
\text { gekomen zijn, kan u die hier meegeven }\end{array}$} & & & & & \\
\hline \multirow[t]{5}{*}{20} & \multirow{5}{*}{\multicolumn{2}{|c|}{ Hoe hebt $u$ het project ervaren? }} & \multicolumn{5}{|c|}{ Heel negatief } \\
\hline & & & \multicolumn{5}{|c|}{ Negatief } \\
\hline & & & \multicolumn{5}{|c|}{ Neutraal } \\
\hline & & & \multicolumn{5}{|c|}{ Positief } \\
\hline & & & \multicolumn{5}{|c|}{ Heel positief } \\
\hline \multirow[t]{5}{*}{21} & \multirow{5}{*}{\multicolumn{2}{|c|}{ Hoe vond $\mathrm{u}$ de prijs van de licentiejacht? }} & \multicolumn{5}{|c|}{ Heel laag } \\
\hline & & & \multicolumn{5}{|c|}{ Laag } \\
\hline & & & \multicolumn{5}{|c|}{ Neutraal } \\
\hline & & & \multicolumn{5}{|c|}{ Hoog } \\
\hline & & & \multicolumn{5}{|c|}{ Heel hoog } \\
\hline \multirow[t]{5}{*}{22} & \multirow[t]{5}{*}{$\begin{array}{l}\text { Hoe verliepen de } \\
\text { volgende } \\
\text { samenwerkingen? }\end{array}$} & $\begin{array}{l}\text { Tussen de licentiejagers in het } \\
\text { algemeen }\end{array}$ & 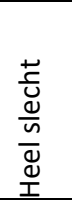 & 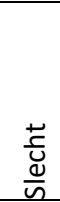 & 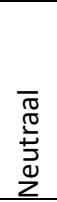 & 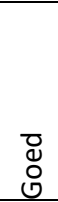 & 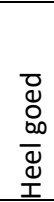 \\
\hline & & $\begin{array}{l}\text { Tussen de licentiejagers in het } \\
\text { algemeen }\end{array}$ & & & & & \\
\hline & & Met de boswachters & & & & & \\
\hline & & Met de regiobeheerder & & & & & \\
\hline & & $\begin{array}{l}\text { Wanneer } u \text { aangeeft dat de sam } \\
\text { aanleiding volgens } u \text { ? Suggesties }\end{array}$ & $\begin{array}{l}\text { werkir } \\
\text { por ve }\end{array}$ & $\begin{array}{l}\text { opti } \\
\text { ing? }\end{array}$ & rliep, & as hie & \\
\hline \multirow[t]{5}{*}{23} & \multirow{5}{*}{\multicolumn{2}{|c|}{ Hoe gebruiksvriendelijk vindt u het jachtdagboek? }} & \multicolumn{5}{|c|}{ Helemaal niet gebruiksvriendelijk } \\
\hline & & & \multicolumn{5}{|c|}{ Niet gebruiksvriendelijk } \\
\hline & & & \multicolumn{5}{|c|}{ Neutraal } \\
\hline & & & \multicolumn{5}{|c|}{ Gebruiksvriendelijk } \\
\hline & & & \multicolumn{5}{|c|}{ Heel gebruiksvriendelijk } \\
\hline \multirow[t]{3}{*}{24} & \multirow{3}{*}{\multicolumn{2}{|c|}{$\begin{array}{l}\text { Zijn er invulmogelijkheden/opties die momenteel } \\
\text { ontbreken in jachtdagboekjes? }\end{array}$}} & \multicolumn{5}{|l|}{ Ja } \\
\hline & & & Nee & & & & \\
\hline & & & Indie & vat? & & & \\
\hline 25 & Zou u een digitale & verkiezen boven & $\mathrm{Ja}$ & & & & \\
\hline & jachtdagboekjes? & & Nee & & & & \\
\hline
\end{tabular}

